PRISCILA PASQÜETTO MENDONÇA

\title{
ESTUDO COMPARATIVO DAS CARACTERÍSTICAS \\ CITOGENÉTICAS E MOLECULARES DE Triatoma maculata E \\ Triatoma pseudomaculata (TRIATOMINAE, HETEROPTERA)
}

\begin{abstract}
Dissertação apresentada ao Instituto de Biociências, Letras e Ciências Exatas (IBILCE/UNESP) - São José do Rio Preto para obtenção do título de Mestre em Genética.
\end{abstract}

Orientadora: Profa. Dra. Maria Tercília Vilela de Azeredo Oliveira Co-orientadora: Profa. Dra. Lilian Castiglioni 
Mendonça, Priscila Pasqüetto.

Estudo comparativo das características citogenéticas e moleculares de Triatoma maculata e Triatoma pseudomaculata / Maria Paula dos Santos Cavalcanti. - São José do Rio Preto : [s.n.], 2010.

$90 \mathrm{f.}:$ il. ; $30 \mathrm{~cm}$.

Orientador: Maria Tercília Vilela de Azeredo Oliveira

Dissertação (mestrado) - Universidade Estadual Paulista, Instituto de Biociências, Letras e Ciências Exatas

1.Citogenética. 2. Triatoma. 3. Espermatogênese. 4. Triatomíneos. 5. DNA ribossômico. 6. Cromossomos holocêntricos. I. Azeredo-Oliveira, Maria Tercília Vilela de. II. Universidade Estadual Paulista, Instituto de Biociências, Letras e Ciências Exatas. III.Título.

CDU - 575

Ficha catalográfica elaborada pela Biblioteca do IBILCE

Campus de São José do Rio Preto - UNESP 
PRISCILA PASQÜETTO MENDONÇA

\title{
ESTUDO COMPARATIVO DAS CARACTERÍSTICAS CITOGENÉTICAS E MOLECULARES DE Triatoma maculata E Triatoma pseudomaculata (TRIATOMINAE, HETEROPTERA)
}

\author{
COMISSÃO JULGADORA \\ DISSERTAÇÃO PARA OBTENÇÃO DO GRAU DE MESTRE
}

Titulares:

Profa. Dra. Maria Tercília Vilela de Azeredo Oliveira

(Presidente e Orientadora)

Prof. Dr. João Aristeu da Rosa

Prof. Dr. Carlos Roberto Ceron

Suplentes:

Prof. Dr. Marcos de Lucca Júnior

Profa. Dra. Hermione Elly Melara de Campos Bicudo

São José do Rio Preto, 19/02/2010. 
Este trabalho foi desenvolvido no Laboratório de Biologia Celular, junto ao Departamento de Biologia do Instituto de Biociências, Letras e Ciências Exatas de São José do Rio Preto (UNESP/IBILCE), com auxílio financeiro do CNPq (Processo no. 132575/2008-6) e da FAPESP (Processo no. 2008/03431-4). 
Dedico esta minha eonquista...

to meu pai querido, Ildemar Prata Mendonȩa, em quem sempre me espelhei buscando manter meus prineípios de moral e étiea. Infelizmente voeê não terá a oportunidade de viver este momento, mas, também, nunea será esquecido e no meu coração estará sempre vivo. Obrigada por me ajudar a escolher os meus eaminhos $\&$ enfrentar com coragem os meus medos. Esteja onde estiver, espero que sinta sempre orgulho de mim, pois me orgulho de ser sua filha.

A minha adorada mãe, por tão completamente saber ser MIন̃e. pelo colo seguro que acolhe e conforta sempre as filhas. Dor me ensinar a descobrir o mundo com alegria desde o primeiro instante. Obrigada por todo trabalho, dedieação, paciêneia, amor, amizade, determinação, altruísmo, disposięão, preocupaȩão, saerifíeio, aleşria, bondade, edueação e por toda uma vida. 
"A morte não existe! O que se dá é apenas uma transformaȩão em nossa maneira de ser.

Não espere que, depois desta, exista outra vida.

Não!

A vida é a mesma.

A vida eterna já está sendo vivida por todos nós. Depois da morte, continuamos a ser o que já somos. portanto, procure ser AGORA, antes da morte, aquilo que voe $\hat{\ell}$ deseja continuar a ser depois da morte. porque a morte não existe!" 


\section{Agradecimentos}

Alo término de mais esta etapa de minha vida, não poderia deixar de agradeeer à colaboração direta ou indireta das pessoas que convivem comigo, as quais contribuíram para a coneretização deste trabalho. Фeixo a todos a minha eterna gratidão.

Primeiramente, gostaria de agradecer àqueles que guiaram os rumos dos meus experimentos, dos meus conhecimentos, da minha formaȩão e, eonsequentemente, deste trabalho. Agradeȩo enormemente à minha orientadora, Profa. Dra. Maria Terélia Vilela de Azeredo Oliveira, que de forma sineera transmite a experiêneia não só de uma grande pesquisadora, mas também de uma orientadora amiga. Obrigada por toda a dedieaȩão e confianȩa depositada em mim ao longo destes anos de convívio, prineipalmente por aereditar no meu potencial e por sua especial contribuição na minha formação acadêmiea e pessoal, sempre me apoiando e ineentivando a realizar as tarefas. Agradeço pela ajuda nos momentos difíeeis, pela luz nos momentos de maior eseuridão, pelo entusiasmo a eada resultado, pelo conhecimento que tentei absorver de nossas conversas, por se preocupar não apenas com questões profissionais como também com a felieidade pessoal. Obrigada por me ajudar a ser biólogia, a ser ģenetieista e a amar o que eu faęo.

đ̀̀ minha eo-orientadora, Lilian Castiglioni, pela confianȩa que vem desde o primeiro contato na graduação, pela oportunidade de desenvolver parte do projeto em seu laboratório, pela preocupaęão com os rumos dos experimentos no laboratório e por sempre garantir que eles continuariam mesmo durante os períodos conturbados. Obrigada pelos conhecimentos teóricos e práticos transmitidos, por seu entusiasmo, dedieação, pelo 
exemplo de seriedade e profissionalismo e, principalmente, pela amizade construída.

Agradeço à colaboração da Profa. Dra. Ester Tartarotti, pelas dieas e conselhos durante o início dos meus trabalhos na área molecular e que, mesmo à distâneia sempre me atendeu e ajudou no que foi preciso.

to Prof. Dr. João Aristeu da Rosa e seus orientados, que me propieiaram a obtenęão do material de estudo, além de todo apoio durante todo esse trabalho.

đ̀ Profa. Dra. Hermione Elly Melara de Campos Bieudo e à Profa. Dra. Lueilene Regina Maschio que contribuíram imensamente para o enriquecimento desta dissertação com suas valiosas suģestões durante o exame geral de qualifieação ao Mestrado.

Alos membros da comissão julgadora, Prof. Dr. João Aristeu da Rosa e Prof. Dr. Carlos Roberto Ceron, pela disponibilidade e aceitaȩão em avaliar o trabalho.

ત̀ Direȩão do IBILCE/UNESP e ao Departamento de Biologia, que forneceram as condiȩões neeessárias que permitiram a realização deste trabalho, e aos funcionários, que sempre me auxiliaram quando neeessário.

Ao Programa de pós-Graduaȩão em Genétiea, do Instituto de Biociêneias, Letras e Ciêneias Exatas (IBILCE/UNESP), sem o qual a pesquisa não poderia ser realizada, em especial, à Profa. Dra. Cláudia Regina Bonini Фomingos, atual coordenadora do programa, por todo seu entusiasmo e ineentivo demonstrado. Agradeço também aos funcionários 
da Seção de Pós-Graduaȩão, pela dedieaȩão com que desempenham suas funȩões.

Al todos os amigos do Curso de Pós-Graduaęão, pela convivêneia e apoio tanto nos momentos mais difíeeis quanto nas horas de alegria.

Ao Conselho Maeional de Đesenvolvimento Científico e Teenológico $(\mathrm{C} N \mathrm{pq})$ e à Fundação de Almparo à Pesquisa do Estado de são Paulo (FADESP) pelo auxílio finaneeiro ao desenvolvimento e divulgạãa desse projeto.

À todos os colegas do Laboratório de Biologia Celular, aos atuais e aos que já partiram, em especial à Fernanda de Souza Monteiro, Nathália paiva Pereira, Keila Cristina Dantas de Mloura, Vietoria Regia Ramos Silva, Fernando César Silva Junior, que sempre lembrarei com earinho. Em especial, gostaria de agradeeer à Vanessa Bellini Bardella, por quem. tenho profunda admiraęão, pelo modelo profissional que é, apaixonada pelos seus estudos. Agradeço por conduzir meus primeiros passos no laboratório, me ensinado tudo o que eu sei sobre eitogenétiea, impreseindivel para minha formaęão. Obrigada também, por ser uma exeelente "eo-eo-orientadora", pela dedieação ao trabalho, na qual tento me espelhar. Agradeço por te me permitido evoluir juntamente com voê̂ no mundo acadêmico e pessoal, por meio de nossas troeas de experiêneias e sugestões durante as diseussões amigas que tivemos.

Às companheiras Maysa Sueei e Tamires Fernanda Vilas Boas Cordeiro Correia, por estarem sempre alegres e dispostas a me ajudar, por falarem demais nos momentos inadequados e por dizerem o que era preciso nos momentos eertos. Obrigada pela cumplieidade, 
companheirismo, por tudo que passamos juntas e pela valiosa amizade conquistada.

to querido amigo Guilherme Pereira Seagion, pelas horas gastas diseutindo sobre filmes, desenhos e outras coisas supérfluas que me proporeionaram alívio nos momentos estressantes. Obrigada pela sua eumplicidade, companheirismo e por tudo que passamos juntos.

Às amigas pós doutorandas, Lucilene Regina Maschio e Rita Luiza Peruquetti, que sempre me apoiaram em todos os momentos, aconselhando e indieando o melhor caminho a ser seguido, auxiliando prineipalmente durante a parte buroerática deste trabalho. Obrigada também, por estarem sempre presentes, por sua amizade e pela oportunidade de dividirmos as aleģrias e tensões do dia a dia.

À amiga Ana Letícia Guerra a quem tive o prazer de aproximar-me durante a realização deste trabalho, agradeço pela amizade e apoio, prineipalmente durante o congresso.

À amiga Leliane silva Commar, pelos esclarecimentos e sugestões durante as análises moleculares deste trabalho.

ત̀ Medevia Bonvino Stafuzza, pelos eadernos emprestados que me ajudaram muito durante meus estudos para a prova da pós-graduação. Agradeço também pela sineera amizade construída durante estes anos.

À colega Rosana silistino de Souza, pelas dúvidas esclarecidas, pela ajuda experiente no laboratório, a qualquer dia e qualquer hora, e por mostrar como um funcionário púbieo deve trabalhar. 
Aos meus pais, Ildemar Prata Mendonȩa (in memorian) e Maria Luiza Pasqüetto Mendonȩa, que com amor e dedieaȩão, tudo fizeram para que eu aleanȩasse mais esta etapa.

À minha irmã, Christiane Jasqüetto Mendonȩa, por toda uma vida de amizade verdadeira.

Ao meu sobrinho, Arthur Mendonȩa Carvalho, que com sua vida, iluminou a minha. Agradeço por sua alegria, energia e por seu imenso amor, o que dá sentido a minha vida.

đ̇ minha "prima”, Carolina, pela amizade, earinho e por sempre lembrar se de mim. Obrigada pelos "empurrões" que proporeionaram este trabalho e por sua constante preocupaęão.

to meu marido, Stevan Honorato Ferreira e Silva, pelo amor, earinho e incentivo na minha luta diária, por estar sempre ao meu lado e por acreditar em mim. Obrigada por suportar e compreender a minha ausêneia, a falta de earinho e atenção, mas estes momentos foram. essenciais para que eu pudesse aflorar os meus pensamentos, minhas hipóteses, e, principalmente, a minha voeação.

E, finalmente, agradeço à Фeus, por me coneeder a vida, e, desta forma, a possibilidade de evoluir. Obrigada pela forȩa que me deste nos momentos em que aereditava não ter mais. 
Tudo tem alguma beleza, mas nem todos são eapazes de ver. Confueio 


\section{SUMÁRIO}

RESUMO

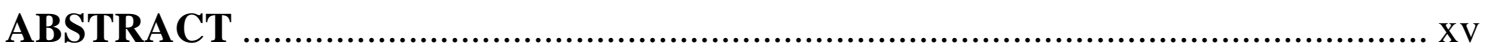

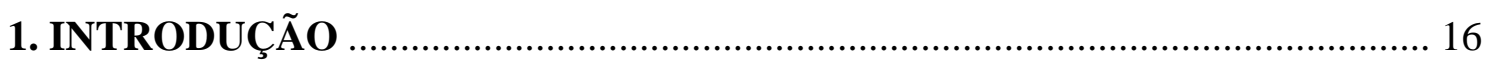

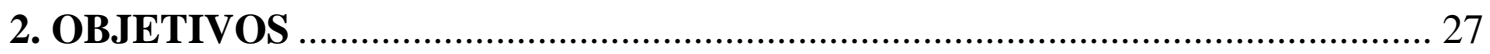

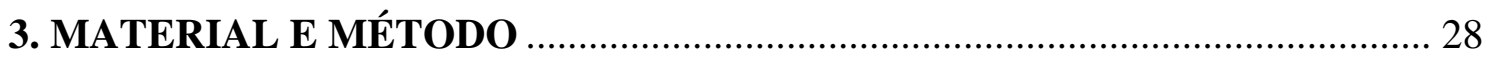

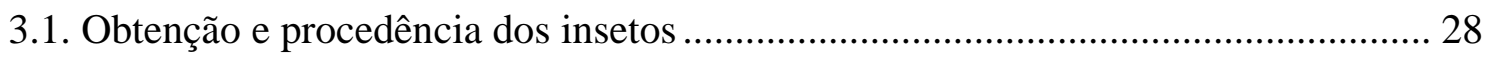

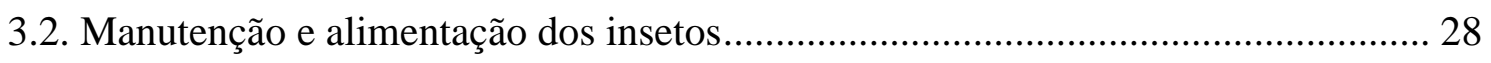

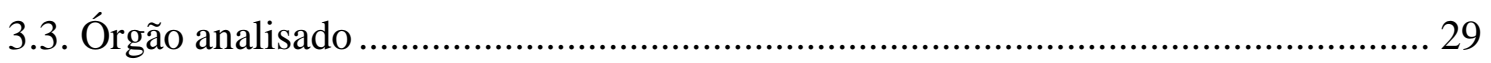

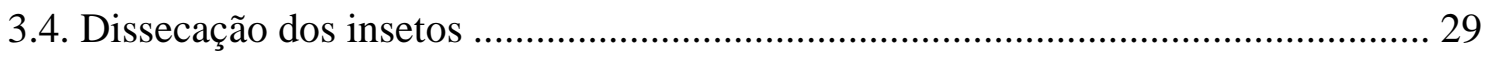

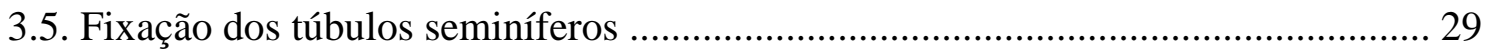

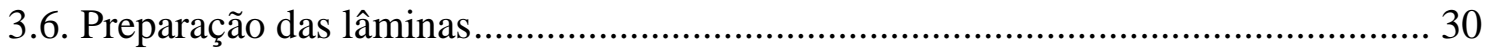

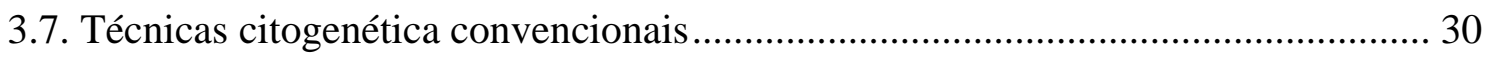

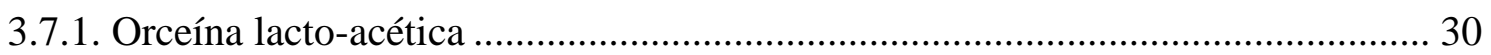

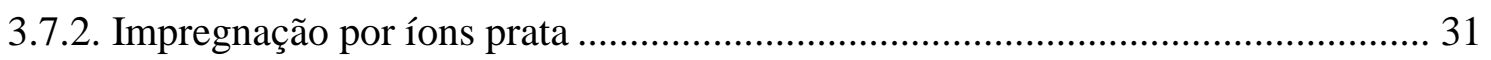

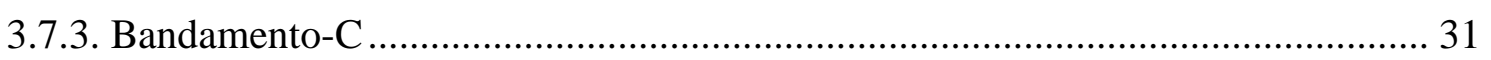

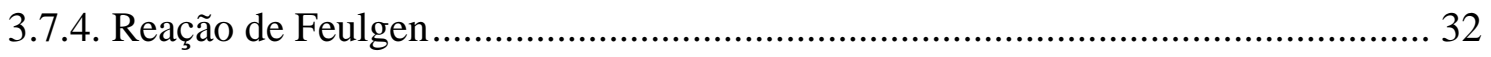

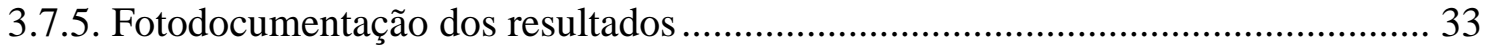

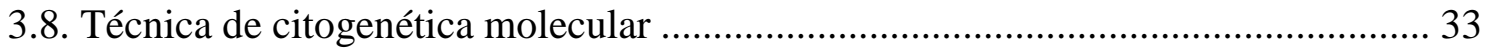

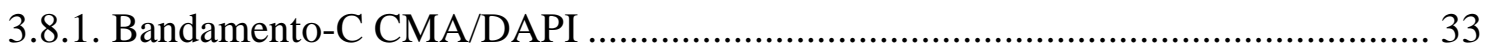

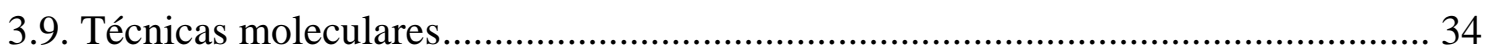

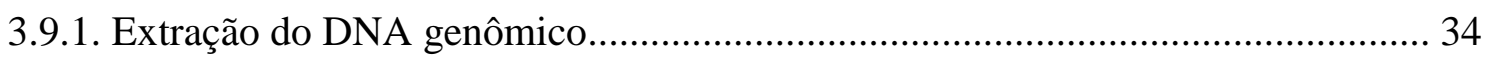

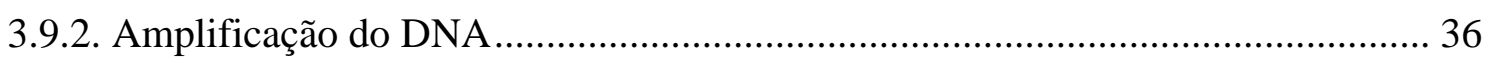

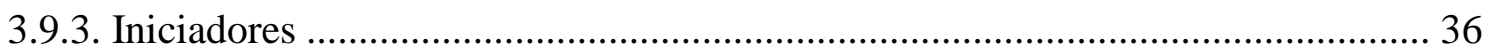

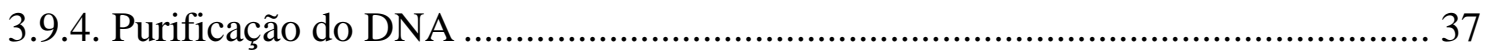

3.9.5. Sequenciamento da região ITS-1 do DNA ribossômico ....................................... 37

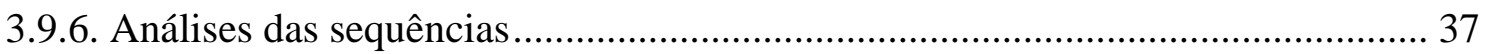

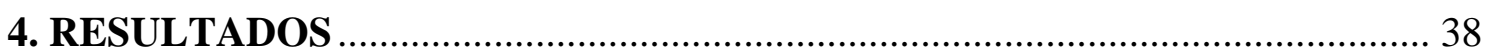

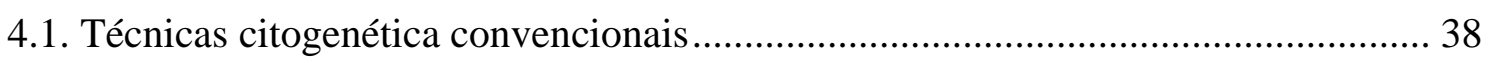

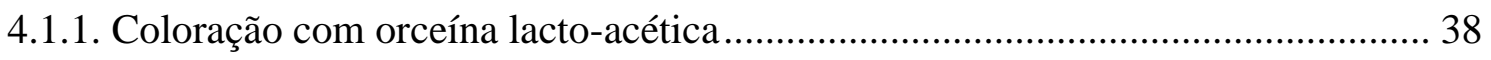

4.1.1.1. Espermatogênese em Triatoma maculata .......................................................... 38

4.1.1.2. Espermatogênese em Triatoma pseudomaculata .......................................... 39 


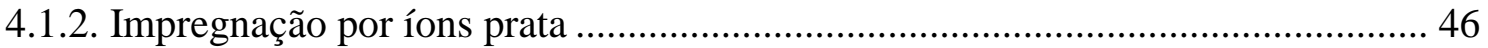

4.1.2.1. Espermatogênese em Triatoma maculata ......................................................... 46

4.1.2.2. Espermatogênese em Triatoma pseudomaculata ........................................... 47

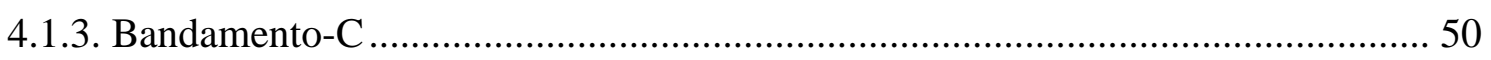

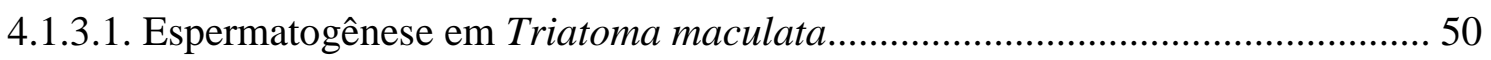

4.1.3.2. Espermatogênese em Triatoma pseudomaculata ............................................. 50

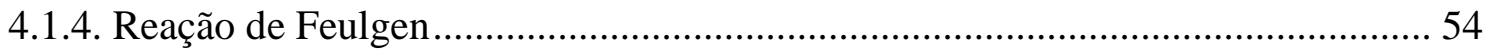

4.1.4.1. Espermatogênese em Triatoma maculata ....................................................... 54

4.1.4.2. Espermatogênese em Triatoma pseudomaculata ........................................... 55

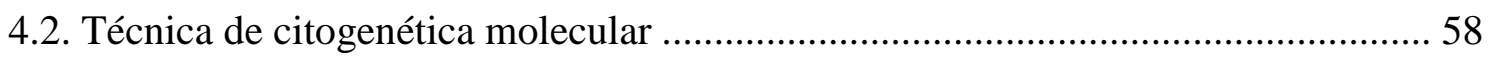

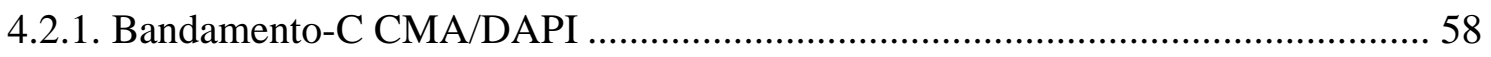

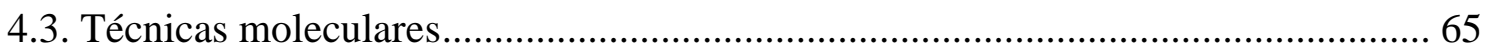

4.3.1. Sequenciamento e alinhamento da região ITS-1 do DNA ribossômico ................ 65

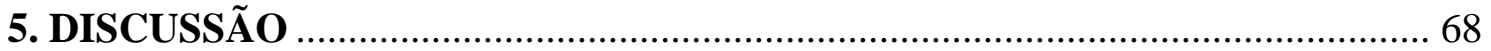

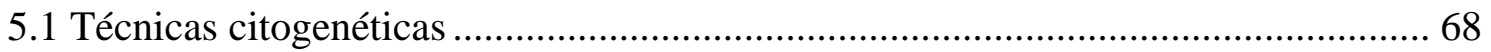

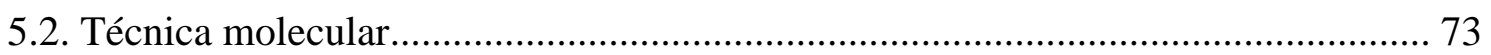

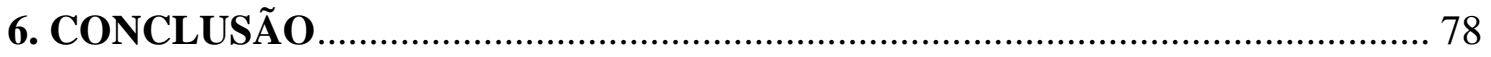

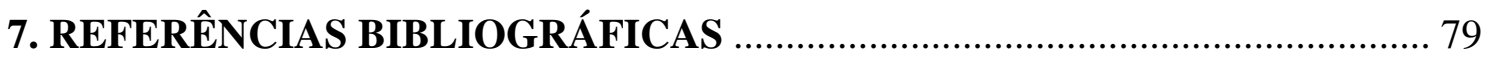

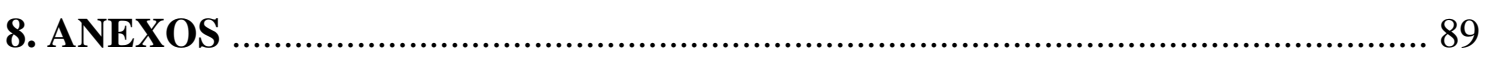

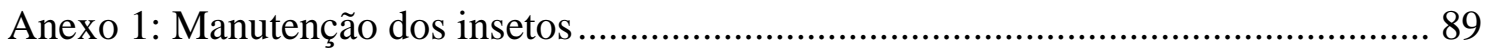

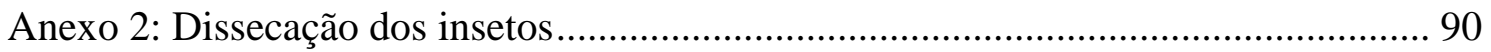




\section{Resumo}

Os triatomíneos são insetos hematófagos de grande importância para a parasitologia humana, pois são transmissores do Trypanosoma cruzi, protozoário causador da doença de Chagas. Além de sua importância médico-sanitária, os triatomíneos destacam-se pela sua citogenética, pois possuem cromossomos holocêntricos e um modelo de meiose incomum, com meiose invertida para os cromossomos sexuais. Recentes pesquisas com marcadores moleculares em triatomíneos tentam compreender a ancestralidade do grupo. Uma das formas de se compreender a evolução entre espécies é a partir da análise de seqüências do DNA ribossômico (DNAr). Por pertencer a famílias multigênicas, cópias individuais do DNAr não acumulam mutações independentemente, resultando em pequena variação intra-específica e relevante diferenciação interespecífica. No presente trabalho foi realizado um estudo comparativo entre as espécies Triatoma maculata e Triatoma pseudomaculata, com base no uso das técnicas citogenéticas convencionais de orceína lacto-acética, impregnação por íons prata, bandamento-C, reação de Feulgen; da técnica de citogenética molecular de bandamentoC CMA/DAPI; e também por meio da análise da região ITS-1 do DNAr, com base no sequenciamento, com o objetivo de avaliar o grau de homologia entre as espécies estudadas. Os cariogramas das duas espécies indicaram dez pares de autossomos (um deles de tamanho maior) e um par de cromossomos sexuais $(2 n=22)$. No ciclo meiótico foi possível observar a fragmentação da região nucleolar no final do estágio difuso. Corpúsculos nucleolares foram observados em alguns dos núcleos em metáfases meióticas de T. pseudomaculata, evidenciando a persistência nucleolar. A técnica de bandamento-C revelou que o cromossomo $\mathrm{Y}$ é heterocromático em ambas as espécies. O sequencimento da região ITS-1, indicou que as espécies apresentaram uma alta proximidade entre si, apresentando 98,5\% de homologia. Os conhecimentos obtidos contribuem para o entendimento da inter-relação, distribuição e expansão dessas espécies, fornecendo assim, novas ferramentas para a profilaxia da Doença de Chagas.

Palavras-chaves: Triatomíneos; Cromossomos holocêntricos; Espermatogênese; Regiões Organizadoras Nucleolares (RONs); Heterocromatina; DNA ribossômico. 


\section{Abstract}

The triatomines are hematophagous insects of great concern in public health because they are vectors of Trypanosoma cruzi, a protozoan that causes Chagas disease. Triatomines are also of great genetic interest, because that they present holocentric chromosomes and an unusual form of meiosis with post-reductional segregation of sex chromosomes. Recent studies based on molecular markers try to understand the evolutionary history of triatomines. To understand the evolution of a given species, ribosomal DNA (rDNA) analyses are frequently used, which can help to infer evolutionary relationships among species. Individual copies of rDNA do not accumulate mutations independently because they belong to multigene families, resulting in slight intraspecific and important interspecific variation. In this study, a comparative analysis was performed between the species Triatoma maculata and Triatoma pseudomaculata, based on the cytogenetic techniques of lacto-acetic orcein, silver ion impregnation, Cbanding, Feulgen reaction; and CMA/DAPI C-banding. We also compared the species by sequencing the ITS-1 rDNA internal transcribed region in order to evaluate the degree of homology among the studied species. The cariograms of the two species revealed ten autosomes and one pair of sexual chromosomes $(2 n=22)$. In the meiotic cycle, nucleolar fragmentation during the final stages of meiotic prophase I was found. Nucleolar corpuscles were found in some meiotic metaphases of T. pseudomaculata, which is evidence of nucleolar persistence. The C-banding technique revealed that the $\mathrm{Y}$ chromosome is heterochromatic in both species. The ITS-1 rDNA sequences showed that the species presented a discharge proximity to each other, and had a high degree of homology $(98.5 \%)$. The knowledge obtained in this study contributes to the understanding of the interrelation and distribution of those species, and offers new tools that can aid in the prevention of Chagas disease.

Key words: Triatomines; Holocentric chromosomes; Spermatogenesis; Nucleolar Organizer Region (RONs); Heterochroamtin; Ribosomal DNA. 


\section{INTRODUÇÃO}

Os triatomíneos possuem grande importância para a parasitologia humana, pois são transmissores do Trypanosoma cruzi, protozoário flagelado causador da doença de Chagas. Esses insetos são hematófagos e pertencem à ordem Heteroptera e à família Reduviidae. Transmitem a doença por seu hábito de defecar, após a hematofagia, sobre os olhos, nariz, boca e outras áreas próximas, visto que esses insetos sugam sangue até se acharem repletos. Neste momento ocorre a passagem das fezes do artrópode para a circulação sangüínea do hospedeiro - o que também pode ocorrer através de micro cortes causados pelo ato de coçar o local por onde o barbeiro sugou o sangue. Os insetos da ordem Heteroptera são compostos por organismos fitófagos (família Pentatomidae), entomófagos e hematófagos, sendo os dois últimos pertencentes à família Reduviidae (SCHOFIELD, 2000)

Dentre os membros da família Reduviidae, aqueles pertencentes à subfamília Triatominae apresentam um destaque médico-sanitário e citogenético. Atualmente são admitidas 143 espécies da subfamília Triatominae que são agrupadas em 18 gêneros. Desses, três são os principais transmissores da doença de Chagas: Triatoma, Panstrongylus e Rhodnius (SCHOFIELD, 2000; GALVÃO et al., 2003; FORERO et al., 2004; COSTA et al., 2006; GALVÃO; ANGULO, 2006; COSTA; FELIX, 2007; SANDOVAL et al., 2007).

Os indivíduos pertencentes à subfamília Triatominae desenvolveram-se a partir de vários grupos pertencentes à família Reduviidae. Primeiramente, apresentavam hábito alimentar predador nos ninhos de aves e mamíferos onde residiam há 50 milhões de anos, passaram, então, a fases de hematofagia facultativa até atingirem a hematofagia obrigatória (SCHOFIELD et al.,1999).

Todos os triatomíneos possuem a capacidade de alojar no seu sistema digestório o Trypanosoma cruzi. Este é o agente etiológico da doença de Chagas. O ciclo de contaminação dos triatomíneos por este protozoário acontece devido ao fato de muito roedores, marsupiais e outros mamíferos estarem primariamente contaminados com o $T$. cruzi. Desta forma, quando os insetos realizam a hematofagia se contaminam com o protozoário e o transmitem a todos os animais reservatório (RAMSEY; SCHOFIELD, 2003).

Alterações no ambiente como seca, devastação e urbanização provocam como conseqüência a diminuição do número de animais por mortes ou migrações. Isso 
ocasiona a falta de alimento aos triatomíneos, o que estimula o processo de vôo nos indivíduos adultos. Estes são atraídos por locais que apresentem emissão de luz, ondas de calor ou odores. Deste modo, ocorre a migração dos triatomíneos do meio silvestre para o meio peridomiciliar ou domiciliar, conseqüentemente aumentando as chances de disseminação da doença de Chagas (RAMSEY; SCHOFIELD, 2003).

Outro fator ambiental que interfere no ciclo de vida dos triatomíneos é o aquecimento global. A elevação da temperatura, seguida da diminuição da umidade, causa o aumento no número de repastos, que, por conseqüência, gera a diminuição do ciclo de vida do inseto, além de aumentar a população e a distribuição dos mesmos (GALVÃO et al., 2000).

O ciclo de vida dos triatomíneos varia de acordo com a espécie e condições ambientais onde vivem e são fortemente influenciados pela disponibilidade de fontes sanguíneas adequadas (SCHOFIELD et al., 1999). Os triatomíneos possuem, após a eclosão dos ovos, cinco instar, para então se tornarem indivíduos adultos, portadores de asas e com maturidade sexual.

Um estudo, em laboratório, sobre o ciclo de vida da espécie Rhodnius brethesi, encontrado no território Amazônico, mostrou que o período médio de incubação dos ovos foi de 17 dias. O tempo médio de desenvolvimento do $1^{\circ}$ estádio até a muda final ocorreu em menos de quatro meses. Observou-se que a quantidade de sangue ingerida foi crescente do $1^{\circ}$ ao $5^{\circ}$ estágio, visto que para a muda de um indivíduo de um estádio para outro há necessidade de pelo menos dois repastos por período entre mudas. Entretanto, os indivíduos adultos apresentaram diminuição da quantidade de sangue ingerido (ROCHA et al., 2004).

Deste modo, para a profilaxia da doença de Chagas, temos que associar dados biológicos dos reduvídeos, que fornecem informações sobre a distinção entre espécies silvestres de baixo risco e espécies domiciliares nocivas, hábitos e horários de hematofagia, capacidade reprodutiva, resistência a inseticidas, ciclo evolutivo, reservatórios domésticos e silvestres do agente etiológico, bem como as inter-relações entre espécies e gêneros estudados no contexto evolutivo, por meio de ensaios citogenéticos que comparam padrões cromossômicos que podem ser aplicados ao estudo da filogenia dos triatomíneos (TAVARES; AZEREDO-OLIVEIRA, 1996; TARTAROTTI, 1998).

Citogeneticamente, o interesse sobre os triatomíneos está em seus cromossomos com cinetócoros difusos (SCHRADER-HUGHES; SCHARADER, 1961 apud DE 
VAIO et al., 1985), ou seja, com distribuição ao longo do cromossomo ao invés da localização na região centromérica. A meiose desses insetos também merece destaque, pois na primeira divisão (anáfase I) os autossomos são quiasmáticos e segregam-se regularmente e os cromossomos sexuais são aquiasmáticos e dividem-se equacionalmente, com segregação desses na segunda divisão (anáfase II), ou seja, com segregação dos cromossomos sexuais pós-reducional (UESHIMA, 1966; SOLARI, 1979).

Estudos citogenéticos revelam que o número diplóide de cromossomos nos machos de Triatominae varia de $2 n=20$ a $2 n=25$ sendo, $2 n=22(20 A+X Y)$ o número cromossômico frequentemente encontrado (UESHIMA, 1966). Entretanto, existem as seguintes exceções para o número de autossomos: Triatoma nitida e Panstrongylus megistus (ambos com 18A) e Triatoma rubrofasciata (22A), caracterizando, assim, a homogeneidade cromossômica (PANZERA et al., 1996).

O número de cromossomos sexuais dos machos da subfamília Triatominae varia entre $\mathrm{XY}, \mathrm{X}_{1} \mathrm{X}_{2} \mathrm{Y}$ ou $\mathrm{X}_{1} \mathrm{X}_{2} \mathrm{X}_{3} \mathrm{Y}$. Desta maneira, as variações de 21 à 25 que ocorrem no conjunto diplóide desses insetos deve-se, principalmente, ao arranjo desses cromossomos. De acordo com Schrader (1947) e White (1973), a hipótese mais aceita para explicar a origem desses múltiplos cromossomos sexuais, é a presença de diferentes sistemas de determinação do sexo, os quais apresentam uma fragmentação do cromossomo $\mathrm{X}$ original do macho. A partir destas evidências, considera-se que o número tipo desta subfamília seja 22 cromossomos $(20 \mathrm{~A}+\mathrm{XY})$, sendo este considerado o representante cromossômico ancestral.

As espécies Triatoma maculata e Triatoma pseudomaculata, objetos desse estudo, também possuem 22 cromossomos, com dez pares de autossomos e um par de heterocromossomos sexuais (20A + XY) (CARCAVALLO et al., 1999).

Grande parte das publicações citogenéticas tem por objetivo o estudo dos cromossomos por meio de coloração convencional. Nesses trabalhos, são consideradas características quanto ao número e a morfologia dos cromossomos, bem como a disposição desses na placa metafásica. Esses dados nos dão suporte quanto à evolução cromossômica desses insetos.

Termos como pré-redução e pós-redução tem sido muito utilizados para a descrição do comportamento dos cromossomos sexuais durante a meiose. Pré-redução significa que os cromossomos segregam-se reducionalmete na primeira divisão. Pósredução significa que a separação equacional dos cromossomos sexuais tem lugar na 
primeira anáfase e a segregação dos cromossomos sexuais ocorre na segunda divisão (TAVARES, 1996).

No Brasil, as análises citogenéticas de triatomíneos foram iniciadas quando Schreiber e Pellegrino (1948) estudaram o cariótipo de onze espécies. Desde então, estudos citogenéticos com esses vetores têm sido concentrados em técnicas convencionais de coloração cromossômica (SCHREIBER; PELLEGRINO, 1951; UESHIMA, 1966; SOLARI, 1979; PANZERA et al., 1995; SEVERI-AGUIAR; AZEREDO-OLIVEIRA, 2005; BARDELLA et al., 2008).

Vários testes citogenéticos são realizados para entender melhor a estrutura e o comportamento dos cromossomos, sendo que um exemplo das técnicas utilizadas é o bandamento-C, que permite a identificação de regiões de heterocromatina nos autossomos e a diferenciação dos cromossomos sexuais (PÉREZ, 1992), uma vez que o cromossomo $\mathrm{Y}$ é quase totalmente heterocromático em relação ao cromossomo $\mathrm{X}$ (PANZERA et al., 1992; PÉREZ et al., 2000). Além disso, segundo Tavares e AzeredoOliveira (1966), com base no conteúdo de heterocromatina-C presente em cada cromossomo, é possível separar as espécies do gênero Triatoma em três grupos distintos, no qual todos, alguns ou nenhum dos pares de autossomos possuem regiões de heterocromatina. De acordo com Panzera et al. (1995), a quantidade e distribuição da heterocromatina-C representa um importante aspecto na diferenciação do cariótipo desses insetos.

Em 1995, Panzera e colaboradores publicaram um trabalho no qual dados sobre o padrão de banda-C, conteúdo de DNA e o processo meiótico de machos de Triatoma platensis e Triatoma delpontei foram comparados com os de Triatoma infestans. Esses autores verificaram que apesar dessas espécies apresentarem certas características semelhantes, tais como, mesmo número diplóide de cromossomos, grandes blocos heterocromáticos autossômicos e cromocentros meióticos heterocromáticos, elas possuem diferenças quanto ao comportamento cromossômico meiótico, conteúdo de DNA, além de quantidade e localização específica da heterocromatina. A análise dos dados citogenéticos sugere que $T$. infestans e $T$. platensis são espécies mais relacionadas uma com a outra do que T. delpontei (TARTAROTTI, 1998).

Outro alvo de estudo para vários autores têm sido as regiões organizadoras nucleolares (RON) em Heteroptera (CAMACHO et al., 1985; FOSSEY; LIEBENBERG, 1995; PAPESCHI; CATTANI, 2004). Estas regiões com as quais os 
nucléolos se associam e que são responsáveis pela reorganização destes, no final da divisão celular, também abrigam o DNA ribossômico, que é transcrito em RNA ribossômico, componente fundamental dos ribossomos. Estudos das RONs de insetos, bem como outros eucariotos, mostram que essas regiões são variáveis quanto a vários aspectos tais como número, localização, quantidade e organização do conteúdo do DNAr e mecanismos reguladores em seu controle. Os locais de formação de alguns nucléolos, regiões organizadoras nucleolares - RONs são geralmente identificados em cromossomos metafásicos monocêntricos como regiões de constrição secundária (BICUDO, 1985).

O número de nucléolos está somente em parte, relacionado ao número de constrições secundárias. Enquanto na mitose as RONs podem ser localizadas em regiões de constrições secundárias, no cromossomo meiótico ela é distinguida como uma região condensada e vista como um grânulo de cromatina (knob). A desagregação do nucléolo ocorre durante o final da prófase e a reorganização na telófase precoce. No entanto, vários exemplos em diferentes espécies de animais e plantas demonstram que especialmente o material fibrilar, mas às vezes o granular, pode persistir ao longo do ciclo celular, incluindo metáfase e anáfase. Essas evidências apóiam a possibilidade de que o material nucleolar não é totalmente sintetizado na RON associada ao cromossomo, mas que um material pré-existente também é necessário e utilizado como já foi referido por Ashraf e Godward (1988) e por outros autores, como Severi Aguiar e Azeredo-Oliveira (2005).

Em triatomíneos, em geral, o número e a localização das RONs são espéciesespecíficas e, como outros grupos animais, cromossomos são marcadores importantes que facilitam a realização de estudos comparativos para uma melhor compreensão dos mecanismos evolutivos destes importantes insetos hematófagos (MORIELLE-SOUZA; AZEREDO-OLIVEIRA, 2007).

Estudos realizados com células somáticas e meióticas de várias espécies de triatomíneos demonstraram claramente esta associação estrutural e funcional entre heterocromatina e o nucléolo (AZEREDO-OLIVEIRA; MELLO, 1986; SEVERIAGUIAR; AZEREDO-OLIVEIRA, 2001). Utilizando-se da técnica de impregnação pela prata, o estudo do ciclo nucleolar de triatomíneos mostrou a presença de regiões organizadoras nucleolares (RONs) em cromossomos metafásicos de Panstrongylus megistus e Triatoma infestans (MORIELLE-SOUZA; AZEREDO-OLIVEIRA, 2008). 
Por meio dessa mesma técnica, também foi possível observar a persistência nucleolar durante o ciclo meiótico em espécies do gênero Triatoma (TAVARES; AZEREDOOLIVEIRA, 1997), Panstrongylus (TARTAROTTI; AZEREDO-OLIVEIRA, 1999) e Rhodnius (MORIELLE, 2000).

Em outro trabalho realizado com túbulos testiculares de Triatoma melanosoma, notou-se a presença de pequenos corpúsculos arginofílicos dispersos na área nuclear no início do "estágio difuso". No mesmo estudo, também foi observado corpúsculos nucleolares dispersos nos mais avançados estágios da meiose, como metáfase I e II e anáfase I e II, relatando o fenômeno da persistência nucleolar em triatomíneos (BARDELLA et al., 2008). Apesar dos diversos estudos com esses insetos, novas investigações com diferentes espécies devem ser feitas a respeito da estrutura nucleolar e da localização das RONs em seus cromossomos holocêntricos (MORIELLE-SOUZA; AZEREDO- OLIVEIRA, 2008).

Aspectos como atividade nucleolar na intérfase e em células meióticas também foram analisadas em Triatoma brasiliensis, Triatoma delpontei, Triatoma. lecticularia, Triatoma rubrovaria e em Triatoma sordida. Nessas espécies, vários blocos nucleolares foram observados nos núcleos poliplóides dos túbulos testiculares, enquanto somente um único corpo nucleolar foi evidente no estágio difuso de T. brasiliensis, T. delpontei, T. lecticularia e T. rubrovaria, sendo que em $T$. sordida foram observadas duas marcações nucleolares. O número de corpúsculos nucleolares presentes nas espermátides de cada espécie variou dentre as espécies, sugerindo uma adicional provisão de informação para a biossíntese de RNAr. É possível que o aumento no número de corpúsculos nucleolares presentes nos núcleos poliplóides esteja relacionado com o aumento na síntese de RNAr nesses núcleos. Além disso, o fato do núcleo espermatogonial possuir vários blocos nucleolares, parece refletir tanto diferenças funcionais como metabólicas. No caso do núcleo espermatogonial, uma reduzida necessidade faz com que um único nucléolo seja suficiente (TAVARES; AZEREDOOLIVEIRA, 1997).

Inferências sobre filogenia nos triatomíneos, em sua maioria, baseiam-se em caracteres morfológicos (LENT, 1979; CARCAVALLO, 1999). Estudos com marcadores isoenzimáticos também foram realizados para a análise de variabilidade genética no grupo. Em geral, um alto grau de monomorfismo tem sido observado nestes insetos, além de baixa variabilidade genética (DUJARDIN et al., 1998; SCHOFIELD; DUJARDIN, 1999; SOARES et al., 1999; MONTEIRO et al., 1999). 
O estudo das tribos Rhodniini e Triatomini, baseado em sistemas enzimáticos, mostrou que espécies e gêneros evoluíram, possivelmente, de ancestrais distintos. Enquanto o gênero Rhodnius apresentou um conjunto de locos e alelos compartilhado entre as espécies estudadas e forte presença de monomorfismo, no gênero Triatoma, além do monomorfismo, observou-se conjuntos de alelos, muitas vezes específicos para uma ou outra espécie. Estes estudos corroboram a hipótese que as tribos Rhodniini e Triatomini evoluiram de ancestrais distintos (SCHOFIELD; DUJARDIN, 1999; BARGUES et al., 2000; MARCILLA et al., 2001).

Para compreender melhor a filogenia dos triatomíneos, iniciaram-se pesquisas com marcadores moleculares (STOTHARD et al., 1998; MONTEIRO et al., 1999, LYMAN et al., 1999; BARGUES et al., 2000, TARTAROTTI; CERON, 2005). O maior objetivo destes estudos é a compreensão da ancestratalidade do grupo. As diferenças morfológicas e a diversidade de habitats dos triatomíneos, bem como suas associações com diferentes animais, que são fontes de sua alimentação, levam à hipótese que esses insetos surgiram a partir de ancestrais distintos (TARTAROTTI et al. 2006), contradizendo, estudos sistemáticos e morfométricos, que postulam uma origem monofilética para os triatomíneos.

Uma das formas de se compreender a evolução entre espécies é a partir da análise de sequências do DNA ribossômico (DNAr). Nos eucariotos, o DNA ribossômico (DNAr) é uma família multigênica, onde os genes ribossômicos $18 \mathrm{~S}, 5,8 \mathrm{~S}$ e $28 \mathrm{~S}$ estão estruturalmente arranjados, em unidades de repetição (RU) (LONG; DAVID, 1980) nas chamadas regiões organizadoras nucleolares (RONs). O organizador nucleolar (NO) é a região cromossômica que contém os genes para o RNAr com a qual o nucléolo se associa e é responsável por sua formação (MCCLINTOCK, 1934).

As unidades repetitivas (RU) ou cistrons ribossômicos consistem de sequências altamente conservadas que codificam os RNAs ribossômicos $18 \mathrm{~S}, 5,8 \mathrm{~S}$ e $28 \mathrm{~S}$, intercaladas com regioes espaçadoras não codificadoras, pouco conservadas entre as espécies. Na maioria dos animais, existem de 100 a 500 cópias dos genes para o DNAr no genoma nuclear (HOY, 1994). Cada unidade de transcrição ou unidade repetitiva, é constituída por uma região ETS (External Transcribed Spacer), a região correspondente ao gene para o RNAr 18S, uma região espaçadora interna transcrita denominada ITS-1 (Internal non Coding Transcribed Spacer), a região correspondente ao gene para o RNAr 5,8S, uma segunda região espaçadora interna transcrita, ITS-2, a regiaõ correspondente ao gene para o RNAr 28S e, finalmente, a região espaçadora intergênica 
não transcrita, IGS (Intergenic non Transcribed Spacer), que separa uma unidade repetitiva de outra, localizada entre os genes $28 \mathrm{~S}$ e $18 \mathrm{~S}$. O esquema apresentado a seguir representa a organização do DNAr em eucariotos, segundo Hillis e Dixon (1991):

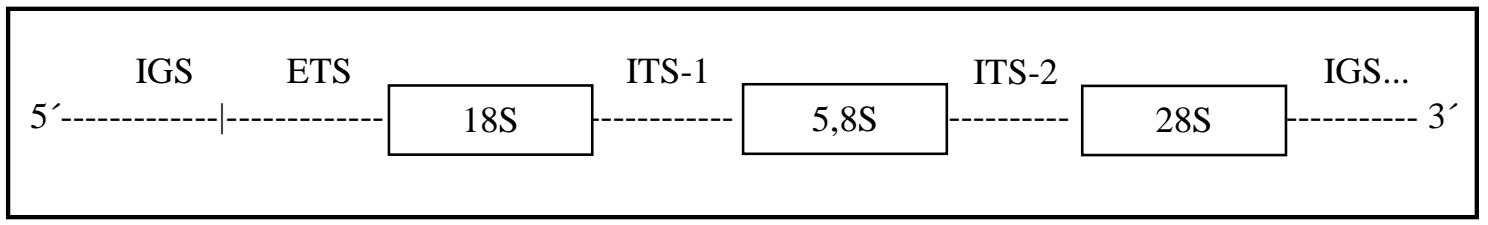

Vários trabalhos indicam que há uma grande variabilidade das regiões intergênicas transcritas ITS-1 e ITS-2, também chamadas de espaçadores internos não codificadores, mesmo entre espécies relacionadas. As sequencias de nucleotídeos dessas regiões espaçadoras transcritas são frequentemente mais polimórficas entre as espécies do que dentro das próprias espécies (MANONMANI et al., 2001). Essa variabilidade que em algumas situações se deve à inserção de elementos transponíveis (TOVAR et al., 2000), tem sido alvo de muitos estudos taxonômicos.

O DNAr é utilizado em estudos filogenéticos de vários níveis taxonômicos, desde filo a populações. Por pertencer a famílias multigênicas, cópias individuais do DNAr não acumulam mutações independentemente, resultando em pequena variação intra-específica e relevante diferenciação inter-específica (ONYABE; CONN, 1999).

Uma das mais notáveis características do DNAr é a homogeneidade de sequências desta família de multigenes que tem sua origem pelo processo de evolução combinada. É amplamente aceito que, neste tipo de evolução, uma simples mutação pode ser fixada em um pequeno espaço de tempo devido ao "crossing over" desigual ou conversão gênica. Este processo de homogeneização é descrito como "deriva molecular". As regiões codificantes apresentam pequena divergência entre espécies relacionadas, enquanto as regiões espaçadoras exibem alta taxa de variabilidade.

As regiões espaçadoras internas transcritas (ITS-1 e ITS-2) do DNA ribossômico são ferramentas importantes para resolver associações entre táxons estreitamente relacionados e constituem excelentes marcadores para distinção entre espécies. As regiões ITSs do DNAr estão normalmente presentes em sequências em tandem, funcionando como importantes marcadores de polimorfismo molecular (MARCILLA et al., 2001). Os ITSs do rDNA nuclear permitem estimativas de eventos evolutivos mais recentes, inferiores a 50 milhões de anos. Essas regiões têm sido utilizadas para estimar 
taxas de relógios moleculares, por exemplo, a região ITS-2 evolui de 23 a 55 vezes mais rapidamente que o DNAr 18S (BARGUES et al., 2000). Muitos organismos têm sido analisados e comparados, com base nas regiões espaçadoras do DNA ribossômico (WHITE, 1998; POLANCO et al., 1998; BAFFI;CERON, 2002).

Análises moleculares em triatomíneos permitiram avaliar o polimorfismo de tamanho de sequência existente nas regiões intergênicas ITS-1 do DNA ribossômico, de oito espécies de triatomíneos: $R$. domesticus, $R$. robustus, $R$. neivai, $T$. brasiliensis, $T$. infestans, T. vitticeps, $P$. megistus e $P$. herreri. A ampla diferença de tamanho das sequências da região ITS-1 do gênero Rhodnius, comparada aos gêneros Triatoma e Panstrongylus, corroboraram estudos sobre a distinta ancestralidade das tribos Rhodniini e Triatomini. Interessantemente, as espécies de Panstrongylus analisadas, apresentaram tamanhos de sequências próximos às espécies de Triatoma, coincidindo com dados filogenéticos que classificam o gênero Panstrongylus como membro da tribo Triatomini (TARTAROTTI; CERON, 2005). Esses dados reforçaram a origem polifilética dos triatomíneos (CARCAVALLO et al., 1999; MARCILLA et al., 2001; BARGUES et al., 2000).

No presente trabalho pretende-se, além da caracterização citogenética, analisar por sequenciamento a região ITS-1 do DNAr das espécies Triatoma maculata e $T$. pseudomaculata para avaliar o grau de homologia entre estas espécies. Essas duas espécies de triatomíneos originalmente consideradas silvestres, com ampla ocorrência na América do Sul, estão se destacando como espécies vetoras emergentes. Dessa forma, o conhecimento da biologia dessas espécies, com ênfase à ecologia e aos estudos genéticos (citogenéticos e filogenéticos) torna-se necessário e importante, em todos os aspectos, para entender a distribuição e expansão dessas espécies e, consequentemente, contribuir com a profilaxia da Doença de Chagas.

A espécie Triatoma maculata é frequentemente domiciliar e habitualmente silvestre, sendo encontrada em ninhos de aves, palmeiras, bromélias epífitas e cavernas, com uma distribuição brasileira pelos estados de Alagoas, Bahia, Brasília (Distrito Federal), Ceará, Goiás, Minas Gerais, Paraíba, Pernambuco, Piauí, Maranhão, Roraima e Rio Grande do Norte (TONN et al., 1978).

Nos últimos 10 anos foi registrado um aumento de incidência da doença na região Amazônica e foi observado que todos os elementos do ciclo de transmissão estão presentes nessa região. Estudos realizados no Estado de Roraima indicam que $T$. maculata deve ser considerada potencialmente vetor do T. cruzi por ter as seguintes 
características: capacidade de infestar ecótopos artificiais no peridomicílio; alimentação frequente durante o período pré-ninfal; ciclo de desenvolvimento relativamente curto com 2,9 gerações/ano; hábitos ecléticos de alimentação; defecação imediata após hematofagia quando ainda no hospedeiro e, também, devido ao fato de ter sido encontrado indivíduos dessa espécies já infectados pelo protozoário (ROJAS et al., 2008; ESPÍNOLA et al., 1981).

Os hábitos alimentares silvestres de T. maculata incluem: aves, roedores, gambás e répteis; no ambiente domiciliar e peridomiciliar as fontes são animais domésticos e o próprio homem. Nas Américas a distribuição inclui a Venezuela, Colômbia, Suriname, Guiana Francesa, Aruba, Bonanire e Curação. Particularmente na Venezuela, T. maculata foi encontrado infestando domicílios em áreas endêmicas, sendo que nestas áreas os espécimes estavam naturalmente infectados pelo $T$. cruzi (LUITGARDS-MOURA et al., 2005).

A espécie Triatoma pseudomaculata é considerada atualmente, como sendo a segunda espécie de maior importância epidemiológica na região nordeste do Brasil, depois de Triatoma brasiliensis. Essa espécie pode ser encontrada frequentemente em ambientes silvestre e peridomicílio, porém ela é ocasionalmente encontrada em habitações humanas (SOUZA et al., 1999; ASSIS et al., 2007). Na natureza, essa espécie pode viver em buracos ou debaixo de troncos secos na região da caatinga, e também, em cactos e ninhos de aves (DIAS-LIMA et al., 2003; CARBAJAL DE LA FUENTE et al., 2008).

T. pseudomaculata é considerada uma espécie endemica das regiões do cerrado e da caatinga, sendo encontrada nos Estados de Alagoas, Bahia, Ceará Goiás, Maranhão, Mato Grosso do Sul, Minas Gerais, Paraíba, Pernambuco, Piauí, Rio Grande do Norte, Sergipe, Tocantins e na cidade de Brasília (DF) (CARACAVALLO; MARTÍNEZ, 1985; CARCAVALLO et al., 1998).

Apesar das espécies $T$. pseudomaculata e $T$. maculata estarem intimamente relacionadas e, por isso, agrupada dentro do complexo T. maculata (CARCAVALLO et al., 1998), estudos recentes tem demonstrado uma relação mais próxima entre $T$. pseudomaculata e outros triatomíneos brasileiros (SANTOS et al., 2007; CARBAJAL DE LA FUENTE et al., 2008). Um dessas espécies, é T. wygodzinskyi, que se encontra distribuida no sul do Estado de Minas Gerais e no Estado de São Paulo (CARBAJAL DE LA FUENTE et al., 2008). T. wygodzinskyi não apresenta um risco epidemiológico devido ao fato de serem restritos ao ambiente silvestre. Ambas espécies compartilham 
grandes similariedades em sua morfologia externa (LENT; WYGODZINSKY, 1979). Apesar destas semelhanças morfológicas e da próxima relação evolutiva compartilhada entre T. wygodzinskyi e T. pseudomaculata, suas características ecológicas são muito diferentes.

Apesar dos conhecimentos relatados sobre os aspectos biológicos comportamentais e ecológicos das espécies Triatoma maculata e T. pseudomaculata, pouco se conhece sobre as características citogenéticas, moleculares e taxonômicas desses insetos hematófagos. O conhecimento de alguns desses parâmetros será importante para se reconhecer a diferenciação entre essas espécies, cujas características morfológicas são semelhantes. 


\section{OBJETIVOS}

Dada a importância citogenética e médico-sanitária dos triatomíneos, o presente trabalho realizou um estudo comparativo entre as espécies Triatoma maculata e Triatoma pseudomaculata, com base no uso de técnicas citogenéticas convencionais e moleculares e de biologia molecular, com os seguintes objetivos:

a) Analisar detalhadamente o comportamento meiótico, a espermiogênese e a estrutura cromatínica, observando as diversas fases da espermatogênese de ambas as espécies e caracterizar as regiões heteropicnóticas, por meio do esmagamento celular de túbulos seminíferos dos testículos de machos adultos corados com orceína lacto-acética;

b) Obter informações sobre o comportamento nucleolar durante a espermatogênese e a localização das Regiões Organizadoras Nucleolares nos cromossomos holocêntricos das espécies citadas, por meio da técnica de impregnação por íons prata;

c) Caracterizar e localizar as regiões heterocromáticas na cromatina e nos cromossomos das espécies estudadas, por meio da técnica de bandamento-C;

d) Analisar o padrão de distribuição e composição de bases das regiões heterocromáticas nos núcleos interfásicos e nos cromossomos meióticos das espécies, utilizando os fluorocromos DAPI e $\mathrm{CMA}_{3}$ durante o bandamento-C;

e) Realizar o sequenciamento da região ITS-1 do DNA ribossomal nuclear;

f) Utilizar os dados obtidos para estabelecer parâmetros comparativos entre T. maculata e T. pseudomaculata e correlacionar as diferenças e semelhanças encontradas no estudo cromossômico entre as espécies estudas para comparar com os dados descritos na literatura. 


\section{MATERIAL E MÉTODO}

\subsection{Obtenção e procedência dos insetos}

As espécies de Triatoma maculata e Triatoma pseudomaculata foram cedidas pelo insetário do Departamento de Ciências Biológicas, Faculdade de Ciências Farmacêuticas do Campus de Araraquara, sob a coordenação do Prof. Dr. João Aristeu da Rosa.

Para os estudos citogenéticos, foram utilizados 20 indivíduos de Triatoma maculata, provenientes de colônias iniciadas a partir de espécimes coletados em Cerro Galaú, Venezuela. Foram utilizados 20 indivíduos da espécie Triatoma pseudomaculata, oriundos de duas colônias provenientes dos Estados de Pernambuco e de Ceará.

\subsection{Manutenção e alimentação dos insetos}

No insetário de Triatominae, do Laboratório de Parasitologia da Faculdade de Ciências Farmacêuticas - UNESP, Campus de Araraquara, as espécies são separadas em colônias de acordo com suas origens. Essas colônias, identificadas como "Colônia de Triatomíneos de Araraquara" (CTA), são mantidas em cristalizadores contendo repartições internas de papelão (para reduzir a luminosidade), fechados em sua parte superior com uma malha fina e guardadas em estantes de madeira, cujos pés ficam imersos em vasilhas contendo óleo queimado, para evitar o ataque de formigas e o apodrecimento da madeira, em salas com pouca iluminação e com temperatura e umidade relativa do ar ambiente (Anexo 1).

Esses insetos são alimentados inicialmente após oito dias da eclosão (ninfa de primeiro estadio) e, posteriormente, são alimentados quinzenalmente com sangue de pato, a fim de se eliminar qualquer possibilidade de contaminação pelo Trypanosoma cruzi, pois as aves não são reservatórios naturais destes protozoários (Anexo 2).

Durante os experimentos, realizados no laboratório de Biologia Celular, do Departamento de Biologia (IBILCE/UNESP), esses insetos foram mantidos em frascos cobertos por uma malha fina amarrada com o auxílio de elásticos para possibilitar a entrada do ar. Cada pote comportou, no máximo, dez indivíduos, não mais do que isso para evitar o estresse e o risco de acidentes no manuseio com estes hematófagos. No 
momento da utilização, os triatomíneos foram retirados com o maior cuidado possível para que deste modo não houvesse a possibilidade de fuga dos mesmos.

\section{3. Órgão analisado}

Foram analisados os túbulos seminíferos de machos de triatomíneos das espécies Triatoma maculata e Triatoma pseudomaculata. Os testículos analisados foram de adultos, pois a espermatogênese em Heteroptera continua na fase adulta, onde foram observadas as mitoses espermatogoniais, os diferentes estágios da meiose e da espermiogênese das espécies estudadas.

\subsection{Dissecação dos insetos}

Os insetos adultos foram eterizados e fixados com alfinetes pela região posterior do cefalotórax (escutelo) em placa de Petri contendo parafina sólida. Em seguida, asas e patas foram retiradas com o auxílio de uma pinça. Sob o microscópio estereoscópico (lupa), as laterais do abdome e os conexivos foram cortados com uma tesoura pontiaguda. Com a ponta dos estiletes, pôde-se abrir a região antero-dorsal no exoesqueleto abdominal, que foi, então, rebatido e, posteriormente, preso com alfinete na placa, expondo o interior da região abdominal. Neste momento, foi gotejada a solução fisiológica (Demerec) sobre o abdome exposto e procedeu-se à retirada dos testículos que estavam localizados na porção anterior do hemocele. Esses órgãos foram depositados em uma lâmina contendo uma gota de solução fisiológica para a retirada dos túbulos seminíferos (Anexo 3).

\subsection{Fixação dos túbulos seminíferos}

Após a dissecação, os túbulos seminíferos foram limpos e individualizados. Posteriormente, foram fixados em solução metanol-ácido acético (3:1) e armazenados no freezer à $-20^{\circ} \mathrm{C}$. 


\subsection{Preparação das lâminas}

Os túbulos seminíferos mantidos na solução fixadora foram colocados, individualmente em uma lâmina limpa, e receberam dois banhos de água destilada, por cinco minutos cada. Após a eliminação de toda a água da lâmina, acrescentou-se uma gota de ácido acético 45\%, durante 10 minutos. Posteriormente, o excesso de ácido acético $45 \%$ foi retirado e, sob o microscópio estereoscópico, o túbulo seminífero foi dilacerado com a ajuda de estiletes e colocou-se, então, uma lamínula para a realização do esmagamento celular. As lamínulas foram retiradas em nitrogênio líquido e, depois, as lâminas foram secas ao ar.

\subsection{Técnicas citogenéticas convencionais}

\subsubsection{Orceína lacto-acética (DE VAIO et al., 1985, com modificações)}

Princípio da técnica: Esta técnica citoquímica diferencia a eucromatina da heterocromatina, corando a segunda mais fortemente que a primeira. Isto ocorre porque na heterocromatina, além de se encontrar maior compactação, a quantidade de proteínas é bem maior que na eucromatina (VIDAL; MELLO, 1987). O mecanismo dessa coloração compreende, de forma simplificada, a ligação das moléculas do substrato carregado positivamente (catiônico) dos grupos amina de resíduos dos aminoácidos protéicos $\left(-\mathrm{NH}_{3}{ }^{+}\right)$, com as moléculas do corante (orceína) que possuem cargas negativas (aniônicas).

A técnica citogenética específica com orceína lacto-acética foi realizada seguindo-se os procedimentos seguintes:

a) Pingar uma gota de orceína sobre a lâmina anteriormente fixada com o túbulo seminífero;

b) Colocar uma lamínula sobre a gota de orceína e aguardar por 5 minutos;

c) Lavar a lâmina em água destilada até que a lamínula se desprenda;

d) Deixar secar ao ar e realizar a montagem total com verniz para observação ao microscópio. 


\subsubsection{Impregnação por íons prata (HOWELL; BLACK, 1980, com modificações)}

Princípio da técnica: A técnica de impregnação por íons prata é um dos métodos clássicos para a identificação das Regiões Organizadoras Nucleolares (RONs), nos cromossomos metafásicos, e das áreas nucleolares, nos núcleos interfásicos. Duas proteínas nucleolares podem ser reduzidas por íons prata: C23 (nucleolina) e B23 (numatrina). Dessas proteínas, somente a C23 está associada ao DNAr, sugerindo ser a "verdadeira proteína AgNOR". O padrão de marcação por íons prata sugere que essas duas proteínas acídicas sejam responsáveis pela impregnação nucleolar: a C23 indica a presença da cromatina descondensada ligada à RON e a B23 indica a localização dos precursores ribossomais (OSCH; BUSH, 1984; CASSEB-HASSAN; AZEREDO-OLIVEIRA, 1999).

A técnica citogenética de impregnação por íons prata foi realizada segundo a técnica abaixo descrita:

a) Tratar a lâmina com o material a ser analisado, com uma gota de solução reveladora (solução de gelatina a $2 \%$ acrescida de $0,5 \mathrm{ml}$ ácido fórmico);

b) Adicionar sobre esta, duas gotas de solução de Nitrato de Prata a 50\% e misturá-las com a ajuda de uma lamínula;

c) Cobrir com lamínula;

d) Colocar as lâminas em placa de Petri contendo papel de filtro umedecido com água destilada, e incubar em estufa a mais ou menos $60^{\circ} \mathrm{C}$, até a mistura das soluções tornarse marrom dourada, cerca de 8 minutos;

e) Lavar a lâmina em água destilada até que a lamínula desprenda-se, deixar secar ao ar;

f) Montar em verniz para observação ao microscópio.

\subsubsection{Bandamento-C (SUMNER, 1982, com modificações)}

Princípio da técnica: Na técnica de bandamento-C, o tratamento com solução básica de hidróxido de bário e solução salina à temperatura elevada, leva à fragmentação e posterior eliminação do DNA do material biológico. No entanto, o DNA da heterocromatina constitutiva não é totalmente extraído, uma vez que sua associação com as proteínas, nesta estrutura, é mais resistente que na eucromatina. Como resultado desse processo, as regiões heterocromáticas coram-se mais fortemente pelo Giemsa, sendo visualizadas ao microscópio de luz, como blocos escuros de cor roxa. Segundo Guerra (1988), o corante Giemsa cora todo o material cromatínico mesmo quando este apresenta pouca quantidade de DNA. 
A técnica citogenética específica de bandamento-C foi realizada seguindo-se os procedimentos abaixo:

a) Tratar a lâmina com $\mathrm{HCl} 0,2 \mathrm{~N}$, à temperatura ambiente por 8 minutos;

b) Lavar uma vez, rapidamente, em água destilada gelada;

c) Lavar uma vez em água destilada à temperatura ambiente;

d) Secar ao ar;

e) Tratar com hidróxido de bário a 5\% filtrado por 6 minutos à temperatura de $60^{\circ} \mathrm{C}$;

f) Banhar a lâmina na seguinte seqüência: água destilada gelada, água destilada com 2 $\mathrm{ml}$ de ácido acético e, novamente, em água destilada gelada;

g) Secar ao ar;

h) Incubar em $2 \mathrm{XSSC}$, pH 7.0, por uma hora, a $60^{\circ} \mathrm{C}$;

i) Lavar em água gelada e esperar secar;

j) Banhar a lâmina por 5 minutos em álcool 70\%, duas vezes;

k) Banhar a lâmina por 5 minutos em álcool 90\%, duas vezes;

1) Esperar secar;

m) Corar com Giemsa a 4\% em tampão fosfato, pH 6.8 (recém-preparado) por 10 minutos;

n) Lavar em água destilada;

o) Secar ao ar e realizar a montagem em verniz cristal para observação ao microscópio.

3.7.4. Reação de Feulgen (MELLO; VIDAL, 1980, com modificações)

Princípio da técnica: A reação de Feulgen foi descrita em 1924, por Feulgen e Rosenbeck, como específica para o DNA, a partir de pesquisas sobre as aplicações do uso de um reagente desenvolvido por Schiff, denominado, reativo de Schiff, sendo utilizado em química orgânica para a caracterização de aldeídos. Como resultado desta reação, forma-se um complexo corado, vermelho violáceo, específico do DNA. Quando esta técnica é aplicada em preparações citológicas, ela mostra que o DNA está localizado no núcleo celular, e, mais precisamente, nos cromossomos. Se a preparação é previamente tratada com desoxirribonuclease, enzima que catalisa especificamente a hidrólise do DNA, nada se cora, o que confere à reação de Feulgen, um valor citoquímico.

A técnica citogenética de reação de Feulgen compreende duas etapas: uma hidrólise ácida em $\mathrm{HCl}$ 4N que provoca a depurinação do DNA, e a exposição do material hidrolisado ao reativo de Schiff que cora somente os aldeídos livres das 
pentoses. Esta técnica citoquímica foi realizada de acordo com os seguintes procedimentos:

a) Realizar a hidrólise ácida com a utilização de $\mathrm{HCl} 4 \mathrm{~N}$, durante uma hora e cinco minutos;

b) Retirar o $\mathrm{HCl} 4 \mathrm{~N}$ e colocar $\mathrm{HCl}$ 0,1N gelado para um rápido banho;

c) Retirar o $\mathrm{HCl}$ 0,1N e adicionar o reativo de Schiff, por 40 minutos em local escuro;

d) Dar três banhos com água destilada por 5 minutos;

e) Secar ao ar e montar a lâmina no dia seguinte em verniz cristal.

\subsubsection{Fotodocumentação dos resultados}

O material submetido às técnicas citogenéticas convencionais foi analisado por meio de observação das lâminas ao microscópio de luz (Olympus BX60), com sistema analisador de imagem Image Pro-Plus - Media Cybernetics, Versão 4.5 para Windows.

\subsection{Técnicas de citogenética molecular}

\subsubsection{Bandamento-C CMA/DAPI}

Princípio da técnica: A técnica de bandamento-C $\mathrm{CMA}_{3} / \mathrm{DAPI}$ é um procedimento de coloração com os fluorocromos CMA (reconhece sítios ricos em GC) e DAPI (reconhece sítios ricos em AT) aplicado após o desgaste cromossômico pelos passos normais do bandamento-C: hidrólise ácida, relaxamento dos cromossomos com hidróxido de bário $5 \%$ e retirada de cromatina em 2 xSSC. Este tipo de tratamento oferece um maior contraste entre as regiões marcadas pelos fluorocromos e o restante dos cromossomos. Esta técnica proporciona uma melhor diferenciação entre regiões ricas em GC $\left(\mathrm{CMA}^{+} / \mathrm{DAPI}\right)$ e AT $\left(\mathrm{CMA} / \mathrm{DAPI}{ }^{+}\right)$.

Para a realização desta técnica de citogenética molecular, utilizou-se o seguinte protocolo:

a) Tratar a lâmina com $\mathrm{HCl} 0,2 \mathrm{~N}$, à temperatura ambiente por 8 minutos;

b) Lavar uma vez, rapidamente, em água destilada gelada;

c) Lavar uma vez em água destilada à temperatura ambiente e secar ao ar;

d) Tratar com hidróxido de bário a 5\% filtrado por 6 minutos à temperatura de $60^{\circ} \mathrm{C}$; 
e) Banhar a lâmina rapidamente em: água destilada gelada, água destilada com $2 \mathrm{ml}$ de ácido acético e, novamente, em água destilada gelada;

f) Secar ao ar;

g) Incubar em $2 \mathrm{XSSC}$, pH 7.0, por uma hora, a $60^{\circ} \mathrm{C}$;

h) Lavar em água gelada e esperar secar;

i) Banhar a lâmina por 5 minutos em álcool 70\%, duas vezes;

j) Banhar a lâmina por 5 minutos em álcool 90\%, duas vezes;

k) Esperar secar;

1) Executar a coloração com fluorocromos no escuro (luz reduzida): pingar $30 \mu \mathrm{lde}$ CMA sobre o material e cobrir com uma lamínula de plástico;

m) Colocar a lâmina em local escuro, de preferência, em uma caixa protegida da luz durante uma hora e meia;

n) Retirar a lâmina em água destilada rapidamente;

o) Secar a lâmina com o auxílio de uma bomba de ar manual;

p) Pingar $30 \mu \mathrm{l}$ de DAPI sobre o material e cobrir novamente com uma lamínula de plástico;

r) Guardar a lâmina em local escuro e aguardar meia hora;

s) Retirar a lamínula e secar com jatos de ar;

t) Montar a lâmina em glicerina.

O material submetido à técnica de bandamento-C CMA/DAPI foi analisado em microscópio de fluorescência.

\subsection{Técnicas moleculares}

\subsubsection{Extração do DNA genômico}

As etapas que envolvem metodologias moleculares foram desenvolvidas em parceria com a Profa. Dra. Ester Tartarotti, junto ao Laboratório de Vetores (Departamento de Biologia, Instituto de Biociências, Letras e Ciências Exatas IBILCE-UNESP), sob a responsabilidade da Profa. Dra. Hermione Elly Melara de Campos Bicudo, pois no laboratório de Biologia Celular ainda não há os equipamentos necessários para a realização das técnicas moleculares. 
O órgão utilizado para a extração do DNA foram os testículos de indivíduos adultos. A escolha desse material biológico pode ser justificada pelo fato desse órgão ser totalmente isolado, envolto por uma membrana e isento de qualquer contaminação dos resíduos alimentares dos insetos hematófagos, proporcionando uma amostra pura. Além deste aspecto, é também de fácil obtenção durante a dissecação do triatomíneo.

Os testículos foram macerados em $600 \mu \mathrm{l}$ de tampão uréia. Posteriormente, foram incubadas por 30 minutos, a $37^{\circ} \mathrm{C}$. Em seguida, adicionou-se $3 \mu l$ de proteinase $\mathrm{K}$ e a mistura foi novamente incubada por 2 horas, a $45^{\circ} \mathrm{C}$. Após este período, adicionouse $500 \mu \mathrm{l}$ de fenol/clorofórmio, inverteu-se manualmente por 5 minutos, realizou-se uma leve agitação ao vortex, por 5 segundos e a solução foi incubada por 30 minutos, a $37^{\circ} \mathrm{C}$. O material foi centrifugado por 25 minutos, a $13 \times 10^{3} \mathrm{rpm}$, e a fase aquosa foi removida para um novo eppendorf.

Para a obtenção de uma amostra mais pura, algumas etapas foram repetidas com clorofórmio:álcool isomírico. À amostra adicionou-se $500 \mu$ de clorofórmio:álcool isomírico, invertendo-se manualmente por 5 minutos. A mistura foi levemente agitada em vortex por 5 segundos, incubada por 30 minutos a $37^{\circ} \mathrm{C}$, e centrifugada por 25 minutos, a $13 \times 10^{3} \mathrm{rpm}$. A fase sobrenadante foi transferida para um outro eppendorf e o DNA foi precipitado com um décimo do seu volume, então, se o volume do sobrenadante foi de $400 \mu \mathrm{l}$, adicionou-se a este, $400 \mu \mathrm{l}$ de acetato de sódio 3M e mais $400 \mu \mathrm{l}$ de isopropanol. Para a homogeneização da amostra, os eppendorfs foram agitados levemente e, depois, acondicionados no freezer overnight.

Para a máxima precipitação do DNA, centrifugou-se a amostra por 25 minutos, a $13 \times 10^{3} \mathrm{rpm}$, após a centrifugação, o sobrenadante foi desprezado e o precipitado foi lavado com $500 \mu \mathrm{l}$ de etanol $70 \%$ e, posteriormente, centrifugado por 25 minutos, a $13 \times 10^{3} \mathrm{rpm}$. Com o auxílio da micropipeta, retirou-se o etanol e os eppendorfs foram secos em estufa a $37^{\circ} \mathrm{C}$, por 30 minutos. O DNA foi então eluído em temperatura ambiente, por 24 horas, em $25 \mu 1$ de água ultra pura. Acrescentou-se $2 \mu 1$ de RNAse $(10 \mathrm{mg} / \mathrm{ml})$, a amostra foi incubada por 40 minutos, a $37^{\circ} \mathrm{C}$ e por 15 minutos adicionais a $65^{\circ} \mathrm{C}$ para inativação da RNAse. Finalmente, as amostras foram guardadas em alíquotas no freezer para posterior quantificação e utilização. 


\subsubsection{Amplificação do DNA}

A amplificação do segmento interno transcrito - ITS-1, foi realizada segundo as recomendações do fabricante da Taq DNA polimerase (Platinum Taq DNA Polymerase - Invitrogen) utilizando as seguintes condições de reação no termociclador: desnaturação inicial do DNA a $94^{\circ} \mathrm{C}$ por 1 minuto; ciclo de desnaturação $\left(94^{\circ} \mathrm{C}\right.$, por 30 segundos), anelamento $\left(55^{\circ} \mathrm{C}\right.$, por 30 segundos $)$ e polimerização $\left(72^{\circ} \mathrm{C}\right.$, por 1 minuto), repetidos por 35 vezes; e extensão adicional com um ciclo de 4 minutos a $72^{\circ} \mathrm{C}$.

Ainda, segundo as instruções do fabricante, para a amplificação do segmento utilizou-se $1 \mu \mathrm{l}$ de cada primer (foward e reverse), $1 \mu \mathrm{l}$ de DNTP, 0,2 $\mu \mathrm{l}$ de taq DNA polimerase (Platinum Taq DNA Polymerase - Invitrogen) com sua respectiva solução tampão $(5 \mu \mathrm{l})$ e $1,5 \mu \mathrm{l}$ de cloreto de magnésio, $1 \mu \mathrm{l}$ da amostra e água ultra pura para completar o volume de $50 \mu \mathrm{l}$.

\subsubsection{Iniciadores}

A sequência completa da região intergênica transcrita, ITS-1, foi amplificada utilizando-se o iniciador Foward (5' CCTAACAAGGTTTCCGTACC 3') que se associa à extremidade $3^{\prime}$ do gene $18 \mathrm{~S}$ do DNAr e o iniciador Reverse (5' GCTGCGTTCTTCATCGAC 3' ) que se associa ao início ao início da sequência $5^{\prime}$ do gene 5,8S do DNAr, de acordo com o método descrito por Baffi e Ceron (2002). Estes iniciadores foram desenvolvidos para o estudo da região ITS-1, em espécies de Drosophila, e utilizados em outros estudos, tais como Baffi e Ceron (2002), Tartarotti e Ceron (2005).

Os iniciadores utilizados para amplificação do segmento interno transcrito (ITS1) foram desenvolvidos para o estudo da região ITS-1, em espécies de Drosophila, e utilizados em outros estudos, tais como Baffi e Ceron (2002), Tartarotti e Ceron (2005). Estes primers se anelam à extremidade 3' do gene $18 \mathrm{~S}$ do DNAr, e à extremidade 5' do gene 5,8S do DNAr, de acordo com o método descrito por Baffi e Ceron (2002).

A reação de amplificação foi confirmada pela eletroforese em gel de agarose a $2 \%$, corado com brometo de etídio e visualizada em luz UV. O tamanho dos fragmentos amplificados foi analisado comparando-os com os marcadores moleculares. 


\subsubsection{Purificação do DNA amplificado}

Os fragmentos amplificados foram purificados por meio do kit Concert Rapid PCR Purification system (Invitrogen), de acordo com as instruções do fabricante para, em seguida, serem submetidos ao seqüenciamento.

\subsubsection{Sequencimento da região ITS-1 do DNA ribossômico}

Os produtos gerados pela amplificação foram enviados ao Centro de Estudos do Genoma Humano (CEGH), ligado ao Instituto de Biociências da USP - Universidade de São Paulo.

\subsubsection{Análises das sequências}

A qualidade das sequências foi verificada por meio de eletroferograma criado pelo software BioEdit Sequence Alignment Editor V. 7.0.5 (HALL, 1999). Para as análises filogenéticas, foram utilizadas as sequências consensos obtidas para cada espécie pelo programa BioEdit, com a finalidade de verificar em qual posição ocorreram as divergências de nucleotídeos. 


\section{RESULTADOS}

\subsection{Técnicas citogenéticas convencionais}

\subsubsection{Coloração com orceína lacto-acética}

\subsubsection{Espermatogênese em Triatoma maculata}

A técnica citogenética convencional de orceína lacto-acética permitiu a visualização das regiões heteropicnóticas nos cromossomos holocêntricos da espécie $T$. maculata (Figura 1a). O cariótipo desta espécie (Figura 2), montado baseando-se nas metáfases espermatogoniais e nas metáfases da primeira e segunda divisão meiótica, foi verificado como sendo $2 \mathrm{n}=22(20 \mathrm{~A}+\mathrm{XY})$.

Os núcleos poliplóides das células nutritivas da parede do túbulo seminíferos apresentaram um único corpúsculo heteropicnótico (Figura 3a), assim como os núcleos interfásicos das células espermatogoniais (Figura 3b) que apresentaram um corpúsculo maior e mais evidente na periferia da célula. Nestas células, também foi verificado pequenos corpúsculos heteropicnóticos menores espalhados no interior do núcleo. Os núcleos espermatogonias em prófase evidenciaram a condensação da cromatina na forma de pequenos blocos heteropicnóticos (Figura 3c).

As metáfases espermatogoniais (Figura 3d-f) são diplóides $(20 \mathrm{~A}+\mathrm{XY})$ e apresentaram os 22 cromossomos dispostos por toda a placa equatorial (Figura 3f). Durante esta fase, foi possível acompanhar a condensação dos cromossomos (Figura 3df), mostrando que no início da condensação um dos cromossomos se mostrou mais heteropicnótico do que os demais (Figura 3d). É importante notar que, devido aos diferentes graus de condensação analisados nesta espécie, pode-se verificar que um par de autossomos se mostrou maior que os demais (Figura 3e).

No início da prófase I meiótica, os espermatócitos apresentaram citoplasma claro e um único corpúsculo heteropicnótico próximo a periferia da célula (Figura 3g). Ao longo desta fase, no estágio difuso inicial (Figura 3h), foi possível observar um corpúsculo heteropicnótico bipartido, enquanto que nos estágios difuso médio (Figura 3i) e final (Figura 3j), esse se apresentou de forma compacta. Esses corpúsculos observados no estágio difuso, provavelmente são formados pelos cromossomos sexuais que permaneceram nessa fase meiótica. Durante esses estágios, ficaram evidentes os 
diferentes graus de compactação dos cromossomos e a heteropicnose dos cromossomos sexuais, que se mantiveram próximos até o início na metáfase I (Figura 3k).

As metáfases I da meiose foram observadas em visão lateral, onde os cromossomos apresentaram-se justapostos formando uma "fileira" (Figura 31). Na posição frontal, os cromossomos autossomos formaram um anel contendo os dois cromossomos sexuais (heterocromossomos localizados no centro deste (Figura 3m-q), sendo que o maior heterocromossomo apresentou alto grau de picnose. Em ambos os ângulos, os cromossomos sexuais apresentaram-se individualizados. O conjunto cromossômico apresentou-se de maneira semelhante durante as metáfases da segunda divisão meiótica (Figura 3r-s), entretanto, nesta fase, os cromossomos sexuais apresentaram-se dispostos ponta a ponta.

Durante as anáfases (Figura 3t-u) e telófases (Figura 3v), não foi observado cromossomos apresentando migração tardia, como verificado em T. psedomaculata.

No início da espermiogênese, as espermátides iniciais (Figura 3x) apresentaram forma ovalada e citoplasma abundante, sendo que esta forma foi gradualmente alterada durante o processo de diferenciação (Figura 3x-z). Tanto as espermátides iniciais (arredondadas), como as espermátides em alongamento (Figura 3y), apresentaram um corpúsculo heteropicnótico. Nas fases mais adiantadas da diferenciação dos espermatozóides, o alongamento celular foi mais nítido (Figura 3z).

\subsubsection{Espermatogênese em Triatoma pseudomaculata}

O cariograma de T. pseudomaculata (Figura 1b), baseado nas metáfases espermatogoniais e nas metáfases da primeira e segunda divisão meiótica apresentou o cariótipo igual a $2 \mathrm{n}=22(20 \mathrm{~A}+\mathrm{XY})($ Figura 4$)$.

Os túbulos seminíferos submetidos à técnica de orceína lacto-acética apresentarm núcleos poliplóides com apenas um corpúsculo heteropicnótico localizado na região central da célula (Figura 5a). Os núcleos da célula espermatogonial em intérfase (Figura 5b) apresentaram um corpúsculo fortemente heteropicnótico, enquanto que nos núcleos em prófase (Figura 5c), a orceína corou o material em condensação. As metáfases espermatogoniais desta espécie também foram observadas durante os diferentes graus de condensação cromatínica (Figura 5d-e). No início desta metáfase (Figura 5d) foi verificado um corpúsculo heteropicnótico quase que individualizado e com alto grau de condensação, provavelmente formado por um dos cromossomos 
sexuais. Os núcleos em metáfase mitótica (Figura 5e) apresentaram 22 cromossomos, todos com alto grau de heteropicnose.

Os núcleos no início da prófase I meiótica (Figura 5f-g) apresentaram apenas um corpúsculo heteropicnótico. Ao decorrer do estágio difuso, este corpúsculo se mostrou bipartido (Figura 5h-j). No final da prófase I (Figura 5k) foi evidenciada a condensação dos cromossomos e o corpúsculo heteropicnótico voltou a se apresentar único e com um alto grau de picnose.

As metáfases da primeira divisão meiótica puderam ser observadas ainda em organização (Figura 51-m) até que fossem visualizadas em sua conformação padrão, isto é, os cromossomos sexuais se apresentaram no centro do anel formado pelos cromossomos autossômicos (Figura $5 \mathrm{n}$-q), ou, então, em organização lateral (Figura 5r). As metáfases II foram visualizadas em forma circular (Figura $5 \mathrm{~s}-\mathrm{t}$ ). Em ambas as metáfases, o cromossomo sexual maior mostrou-se mais heteropicnótico.

Durante a anáfase meiótica ocorreu a migração tardia de um dos cromossomos (Figura $5 \mathrm{u}$ ). Estes cromossomos deslocaram-se para os pólos da célula até atingir o estágio de telófase (Figura $5 \mathrm{v}-\mathrm{x}$ ). Ao término da telófase, deu-se início à espermiogênese com a formação das espermátides inciais (Figura $5 \mathrm{w}$ ). Ao longo do processo de alongamento, as espermátides apresentaram regiões heteropicnóticas (Figura 5y) até o final de sua diferenciação (Figura 5z). 


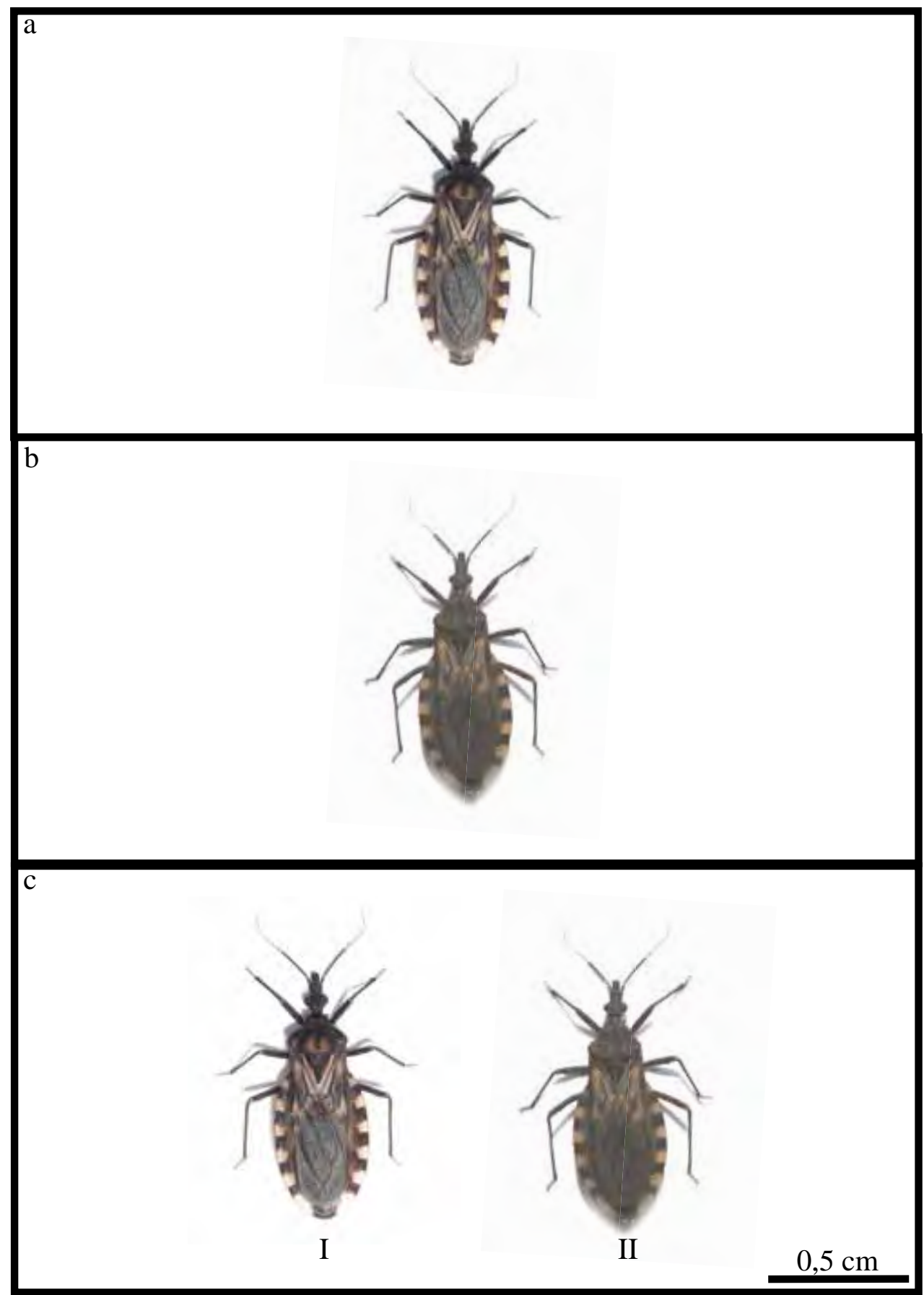

Figura 1: Espécies analisadas. (a) Triatoma maculata, macho. (b) Triatoma pseudomaculata, macho. c) T. maculata, macho (I), T. pseudomaculata, macho (II). 


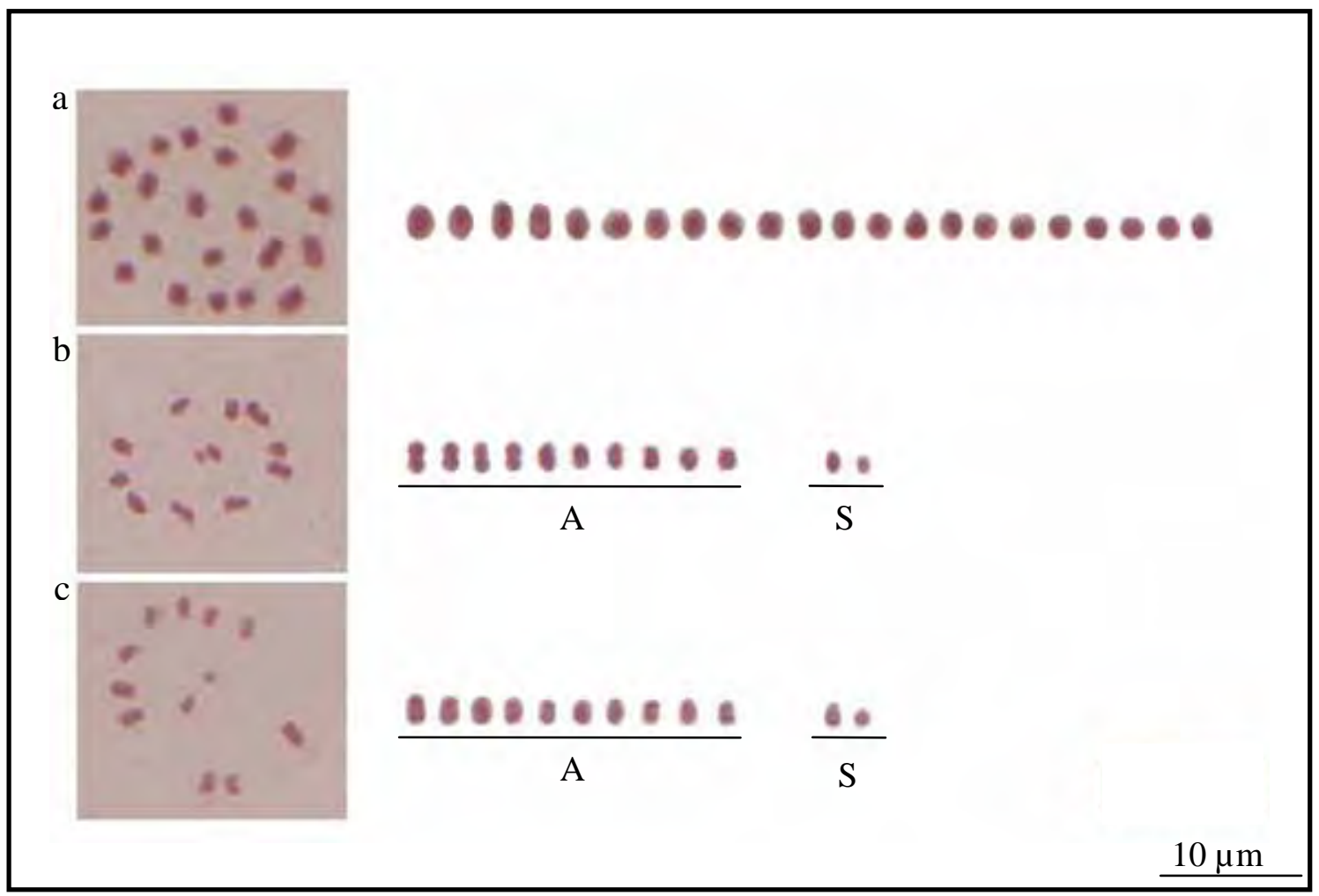

Figura 2: Cariótipos da espécie Triatoma maculata. (a) Metáfase espermatogonial e respectivo cariótipo com 10 pares de autossomos e 2 cromossomos sexuais (XY). (b) Metáfase circular da primeira divisão meiótica e respectivo cariótipo com 10 autossomos bivalentes e 2 cromossomos sexuais (XY). (c) Metáfase circular da segunda divisão meiótica e respectivo cariótipo $(10 \mathrm{~A}+\mathrm{XY}) . \mathrm{A}=$ autossomos; $\mathrm{S}=$ cromossomos sexuais. 


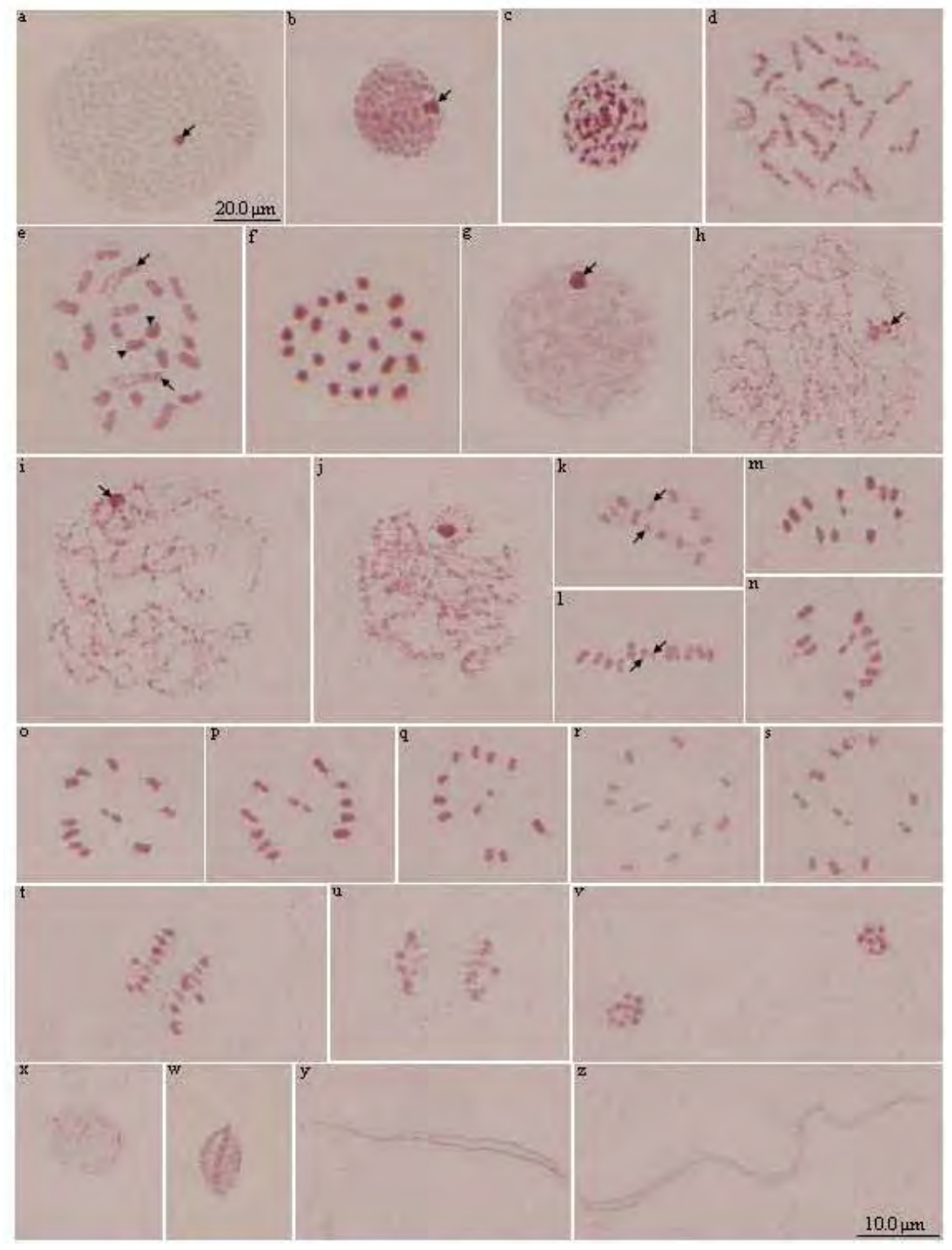

Figura 3: Túbulos seminíferos de T. maculata submetidos à técnica citoquímica de orceína lacto-acética. (a) Núcleo poliplóide com um único corpúsculo heteropicnótico (seta). (b) Núcleo interfásico da célula espermatogonial. A seta indica um corpúsculo heteropicnótico maior e mais evidente. (c) Núcleo da célula espermatogonial em prófase. (d-e) Metáfases espermatogoniais iniciais. Em (e), é possível observar dois cromossomos ainda em condensação (setas) e os cromossomos sexuais heteropicnóticos ao centro do núcleo em divisão (pontas de setas). (f) Metáfase espermatogonial. (g) Espermatócito com uma única marcação heteropicnótica (seta). (h) Núcleo no início da prófase I meiótica (estágio difuso) com um corpúsculo heteropicnótico bipartido (seta). (i) Núcleo em estágio mais avançado da prófase I, apresentando um único corpúsculo heteropicnótico (seta). (j) Núcleos da prófase I meiótica. (k) Início da metáfase I. As setas indicam os cromossomos sexuais. (l) Metáfase I em vista lateral. As setas indicam os cromossomos sexuais entre os autossomos. (m-q) Metáfases I. (r-s) Metáfases II. (tu) Anáfases II. (v) Telófase meiótica. (x) Espermátide no início da espermiogênse. (wy) Espermátide em estágio mais adiantado da espermiogênese. (z) Espermátide na fase final da espermiogênese. 


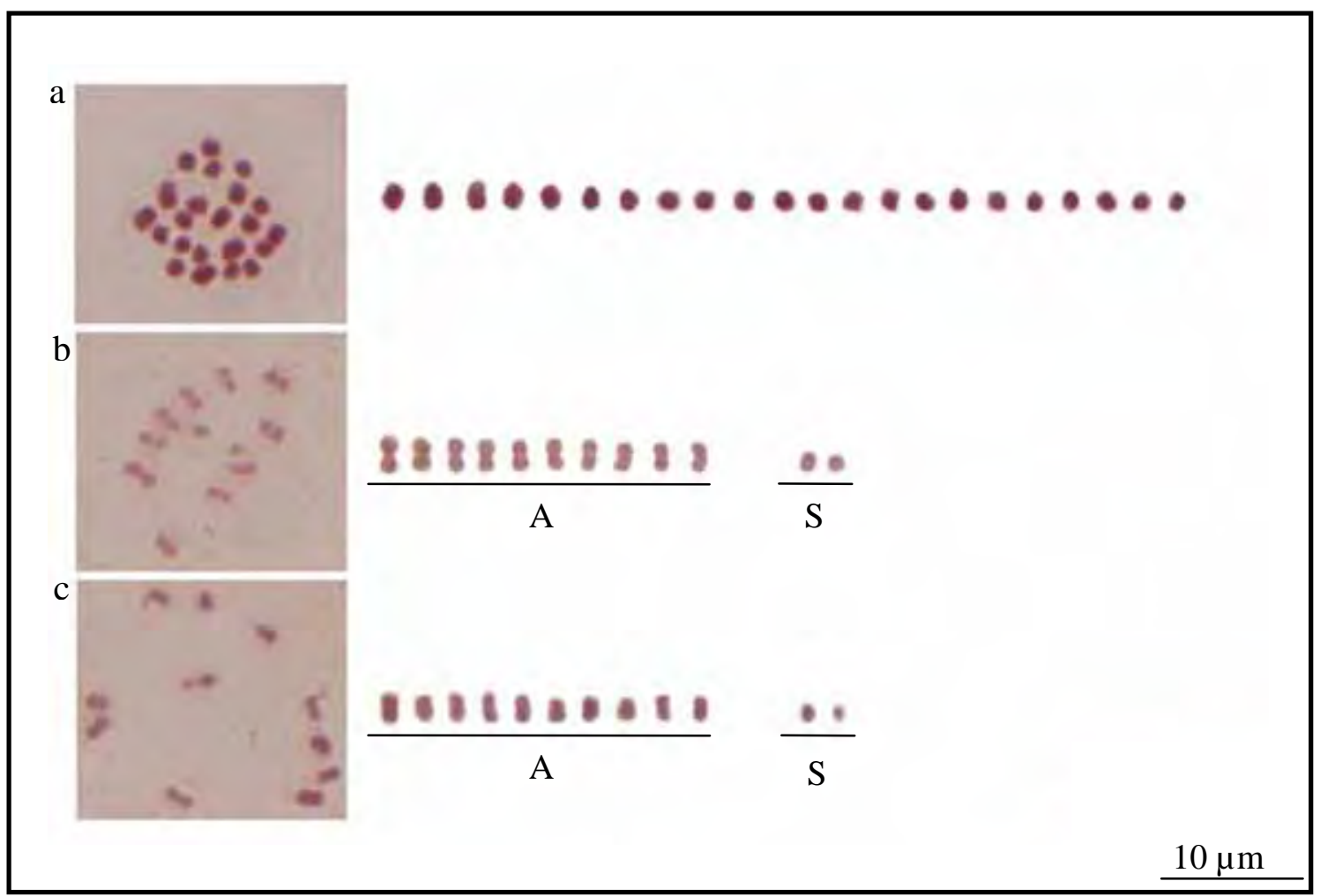

Figura 4: Cariótipos da espécie Triatoma pseudomaculata. (a) Metáfase espermatogonial e respectivo cariótipo com 10 pares de autossomos e 2 cromossomos sexuais (XY). (b) Metáfase cirular da primeira divisão meiótica e respectivo cariótipo com 10 autossomos bivalentes e 2 cromossomos sexuais (XY). (c) Metáfase circular da segunda divisão meiótica e respectivo cariótipo $(10 \mathrm{~A}+\mathrm{XY}) . \mathrm{A}=$ autossomos; $\mathrm{S}=$ cromossomos sexuais. 


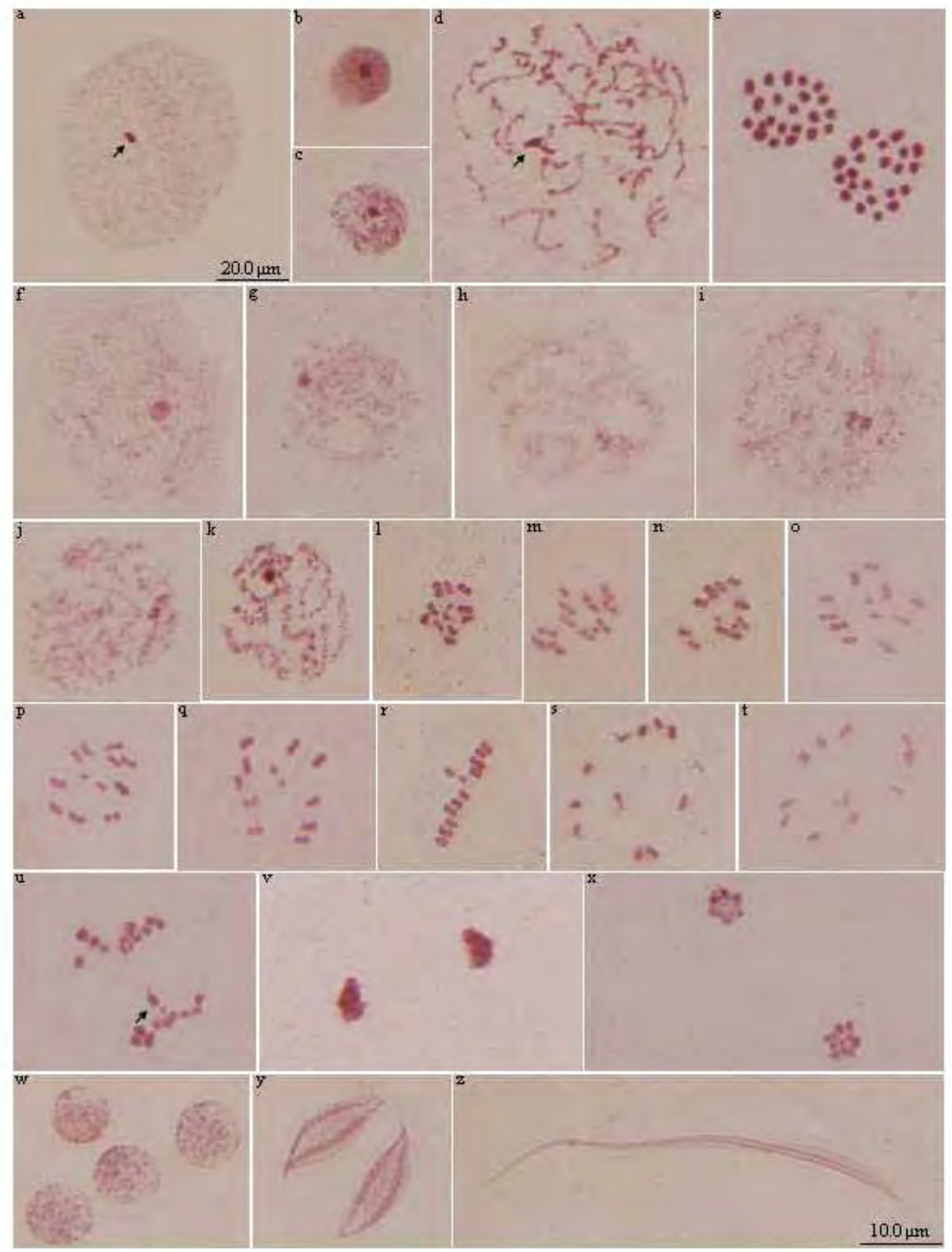

Figura 5: Túbulos seminíferos de T. pseudomaculata submetidos à técnica de orceína lacto-acética. (a) Núcleo poliplóide com um corpúsculo heteropicnótico (seta). (b) Núcleo da célula espermatogonial em interfase. (c) Núcleo da célula espermatogonial em prófase. (d) Início da metáfase espermatogonial. A seta indica um corpúsculo heteropicnótico. (e) Metáfase espermatogonial com 22 cromossomos. (f-g) Início da prófase I meiótica. (h-j) Prófase I meiótica apresentando um corpúsculo heteropicnótico bipartido. (k) Estágio final da prófase I meiótica apresentando um único corpúsculo heteropicnótico. (1-n) Início da metáfase da primeira divisão meiótica. (o-q) Metáfases circulares da primeira divisão meiótica. (r) Metáfase I lateral. (s-t) Metáfases da segunda divisão. (u) Anáfase indicando a migração tardia de um dos cromossomos (seta). (v) Anáfase meiótica em estágio mais avançado. (x) Telófase. (w) Espermátides iniciais. (y) Espermátides em alongamento com regiões heteropicnóticas ao longo da célula. (z) Espermátide em alongamento final. 


\subsubsection{Impregnação por íons prata}

A técnica citoquímica de impregnação por íons prata permitiu evidenciar as massas correspondentes aos nucléolos, por meio da detecção das proteínas nucleolares, as quais se destacaram em marrom escuro.

O ciclo nucleolar foi acompanhado nas células dos túbulos seminíferos no decorrer das diversas fases da espermatogênese, por meio da técnica de impregnação por íons prata (Figura 6).

Os resultados obtidos com essa técnica em testículos de indivíduos adultos de $T$. maculata e T. pseudomaculata, estão descritos a seguir.

\subsubsection{Espermatogênese em Triatoma maculata}

Os núcleos poliplóides da parede do túbulo seminífero apresentaram-se de duas maneiras (Figura 6a-b). Em algumas células, estes núcleos apresentaram-se fortemente impregnados pela prata com a presença de diversos corpúsculos nucleolares, não sendo possível observar uma única marcação definida (Figura 6a). Em outras células, o núcleo poliplóide mostrou várias marcações nucleolares menos impregnadas pelos íons argênticos e apenas uma marcação maior e mais destacada (Figura 6b).

Os núcleos espermatogoniais em intérfase sempre apresentaram uma grande e única marcação (Figura 6c). Nas metáfases espermatogoniais, foi possível verificar pequenas e diminutas marcações nos cromossomos mitóticos que estão indicadas pelas setas (Figura 6d).

Os espermatócitos primários, no início da prófase da primeira divisão meiótica, apresentaram uma região nucleolar nitidamente impregnada pelos íons prata na forma de marcações comumente periféricas (Figura 6e-f, setas). Os núcleos em fase mais adiantada da prófase I meiótica (estágio difuso) mostraram marcações nucleolares tênues que se tornaram mais visíveis ao longo da condensação cromatínica (Figura 6gi). Entretanto, não foram mais observadas ao final do estágio difuso (Figura 6j).

A análise das placas metafásicas das primeira e segunda divisões meióticas, nos permite inferir que nenhuma marcação, nítida ou tênue, foi verificada nesta espécie (Figura 6k-m). Durante essas fases, também não foi verificado corpúsculos nucleolares, e os cromossomos apresentaram intensidades semelhantes pela impregnação íons prata. 
$\mathrm{Na}$ anáfase meiótica (Figura 6n) e na telófase (Figura 6o) não foram verificados fragmentos nucleolares que evidenciariam o reaparecimento do nucléolo. As espermátides, na fase inicial da espermiogênese, apresentaram nitidamente uma única e evidente marcação periférica (Figura 6p), sugerindo atividade nucleolar pós-meiótica, possivelmente relacionada ao processo de diferenciação celular.

\subsubsection{Espermatogênese em Triatoma pseudomaculata}

Os túbulos seminíferos submetidos à técnica de impregnação por íons prata possibilitou a identificação de nucléolos nas células meióticas e as Regiões Organizadoras Nucleolares (RONs) nos cromossomos holocêntricos desta espécie.

Os núcleos poliplóides das células nutritivas da parede dos túbulos seminíferos apresentaram uma única marcação bem evidenciada (Figura 7a). Os núcleos interfásicos espermatogoniais sempre apresentaram apenas uma marcação periférica (Figura 7b). As metáfases mitóticas espermatogoniais (Figura 7c) não apresentaram nenhuma marcação nítida, como descrito para a espécie anterior.

Os núcleos interfásicos espermatogoniais (Figura 7d) e os núcleos em início de prófase I (Figura 7e) responderam à técnica com uma marcação evidente observada frequentemente na periferia da célula. Núcleos em prófase mais avançada (Figura 7f-h) mostraram a marcação única e a presença de pequenos fragmentos nucleolares indicados pelas setas nos estágios finais desta fase (Figura $7 \mathrm{~g}, \mathrm{~h}$ ).

As metáfases de primeira e segunda divisão (Figura 7i-r) mostraram, aparentemente, algumas marcações nos cromossomos, sendo bem evidente a presença de uma marcação em um dos autossomos (Figura 7q) durante a metáfase II. Foi observado também em algumas células um dos cromossomos sexuais fortemente impregnado pela prata (Figura 71,p). É importante ressaltar que neste estágio, em algumas células, aparecem corpúsculos e fragmentos nucleolares dispersos no interior do núcleo, ou próximos do material nuclear. Estes fragmentos responderam positivamente à impregnação pelos íons prata e são, provavelmente, originários da desorganização nucleolar (Figura 7i, k-o, q). No início da espermiogênese, as espermátides apresentaram um único corpúsculo nucleolar periférico, fortemente impregnado pela prata (Figura 7s), o que denota uma atividade nucleolar pós-meiótica semelhante à $T$. maculata, possivelmente relacionada ao processo de diferenciação celular. 


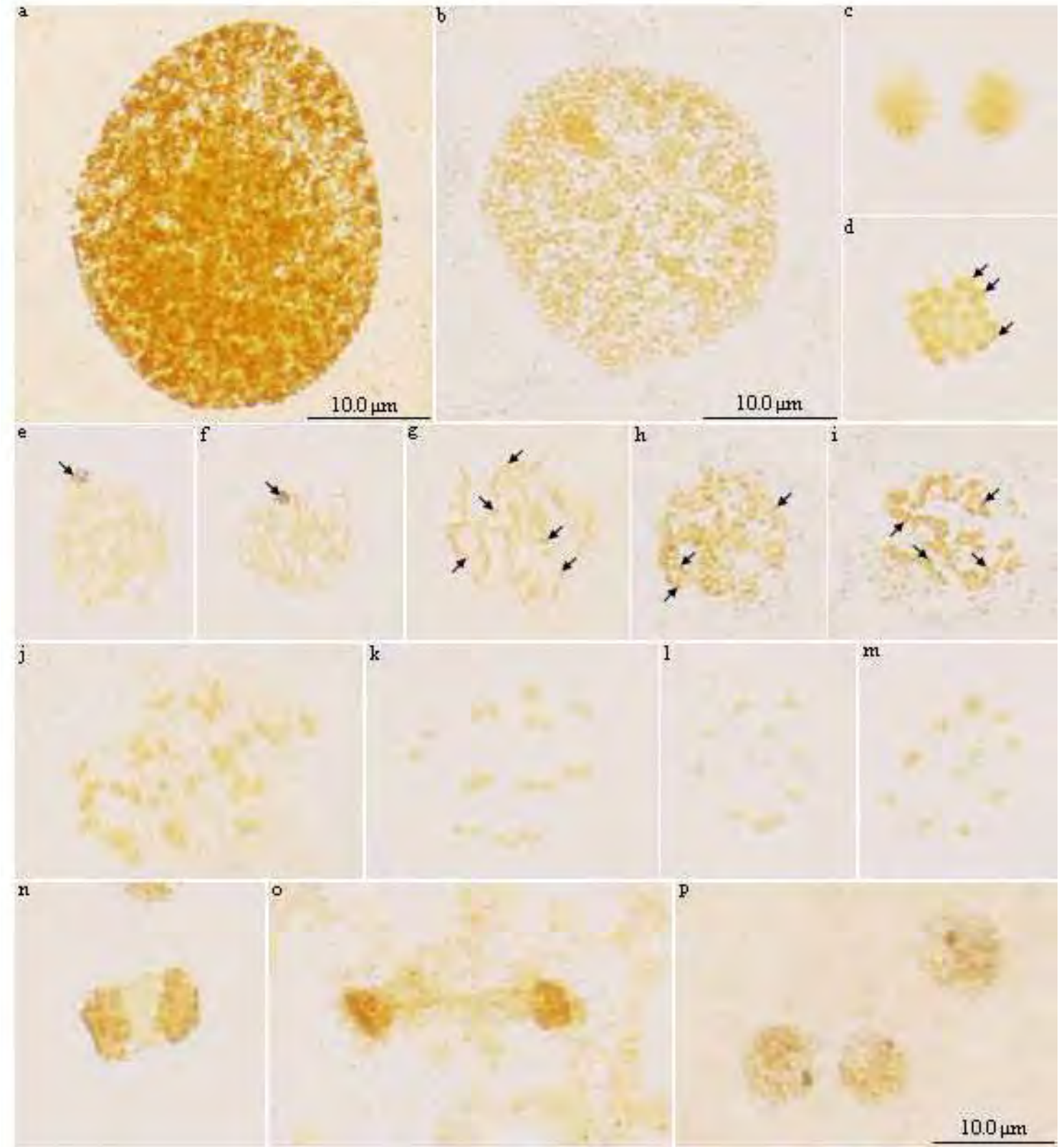

Figura 6: Túbulos seminíferos de T. maculata submetidos à técnica de impregnação por íons prata. (a-b) Núcleos poliplóides. (c) Núcleos espermatogoniais em intérfase. (d) Metáfase espermatogonial com pequenas marcações (setas). (e-f) Espermatócitos com uma marcação nucleolar periféricas (setas). (g-i) Núcleo em estágio difuso. Setas indicam algumas marcações nucleolares. (j) Estágio difuso final. (k-m) Metáfases meióticas. (n) Anáfase meiótica. (o) Telófase. (p) Espermátide. 


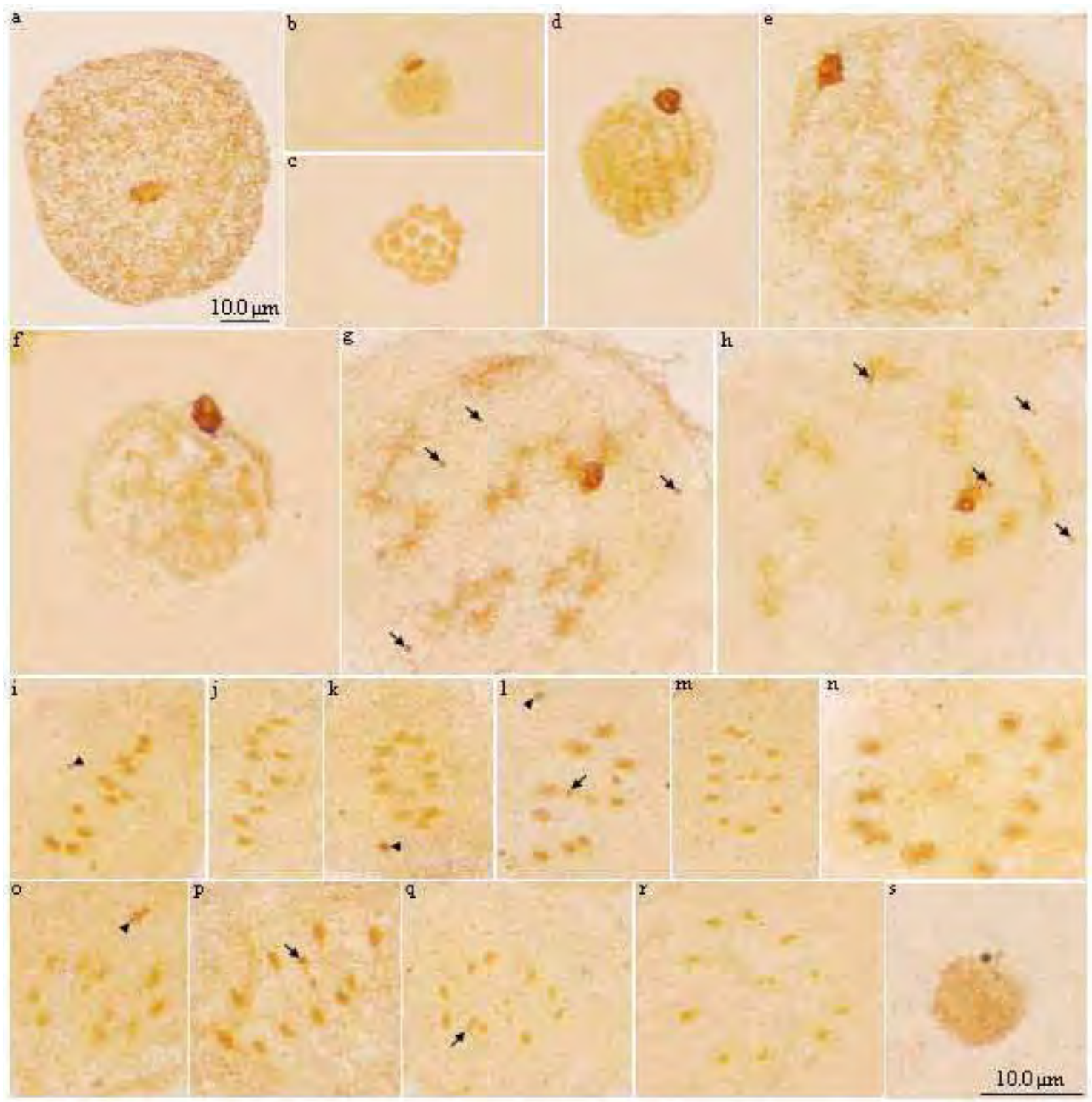

Figura 7: Túbulos seminíferos de $T$. pseudomaculata submetidos à técnica de impregnação por íons prata. (a) Núcleo poliplóide. (b) Núcleo interfásico espermatogonial. (c) Metáfase mitótica. (d) Núcleo dos espermatócitos. (e) Núcleos em início de prófase I. (f-h) Núcleos em prófase mais avançada. As setas indicam pequenos fragmentos nucleolares. (i-m) Metáfases de primeira divisão. (n-r) Metáfases de segunda divisão. Na figura (q), a seta evidencia uma marcação em um dos autossomos. Nas figuras (l) e (p), o cromossomo sexual se mostrou fortemente impregnado pelos íons prata (setas). Durante as metáfases meióticas, foi possível observar a presença de corpúsculos nucleolares, provavelmente originados da desorganização nucleolar (pontas de setas). (r) Espermátide inicial. 


\subsubsection{Bandamento-C}

\subsubsection{Espermatogênese em Triatoma maculata}

A análise dos testículos submetidos ao bandamento-C revelou que, nesta espécie, os núcleos poliplóides apresentaram um corpúsculo fragmentado e heterocromático (Figura 8a).

As metáfases espermatogoniais apresentaram um dos cromossomos totalmente heterocromático (Figura 8b), provavelmente o cromossomo sexual Y.

Os núcleos no início da prófase I da meiose (estágio difuso) mostraram, em algumas células, dois corpúsculos pareados, possivelmente formados pelos cromossomos sexuais, sendo um de maior tamanho e heterocromático (Figura 8c, seta). Durante esta fase, foi possível observar que os cromossomos adquirem, ao longo do tempo, um maior grau de condensação, enquanto que os cromossomos sexuais continuam totalmente heterocromatinizados (Figura 8d-g, setas).

Nas metáfases da primeira divisão meiótica apenas um dos cromossomos apresentou banda- $\mathrm{C}^{+}$, os demais apresentaram coloração homogênea (Figura 8g).

As espermátides, no início da espermiogênese, não apresentaram marcação heterocromática (Figura 8h), entretanto, durante a diferenciação celular, as células em alongamento apresentaram uma bainha heterocromática em apenas uma das regiões (Figura 8i), assim como os espermatozóides (Figura 8j).

\subsubsection{Espermatogênese em Triatoma pseudomaculata}

A técnica convencional de bandamento-C possibilitou a observação de regiões heterocromáticas nos núcleos das células dos túbulos seminíferos de $T$. pseudomaculata. Os núcleos poliplóides apresentaram um único corpúsculo heterocromático e algumas regiões heterocromáticas dispersas pela célula (Figura 9a).

Nas células da prometáfase mitótica espermatogonial foi possível observar um corpúsculo heterocromático durante a condensação dos cromossomos (Figura 9b, seta), também evidente na metáfase mitótica que apresentou 20 cromossomos (Figura 9c).

Durante todo o estágio difuso, esta marcação ficou evidenciada (Figura 9d-f). Na metáfase I, apenas um dos cromossomos sexuais (Y) apresentou-se heterocromático (Figura 9g-i). As espermátides iniciais apresentaram uma região mais heterocromática 
(Figura 9j-k), enquanto que nas espermátides em fase de alongamento foi possível observar o mesmo padrão de distribuição heterocromático encontrado na espécie analisada anteriormente (Figura 91). Os espermatozóides apresentaram apenas a região anterior um pouco mais heterocromática (Figura 9m). 


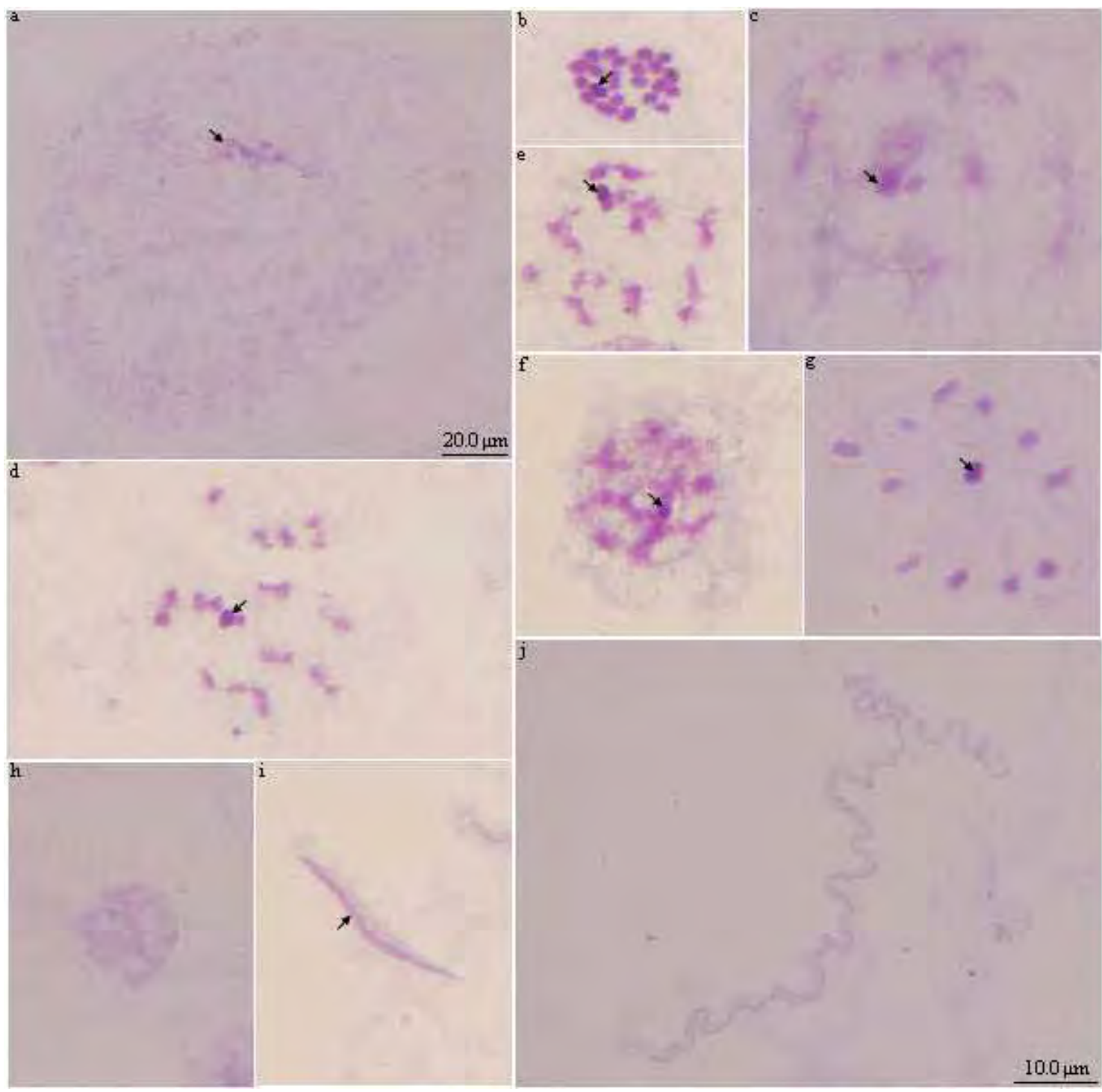

Figura 8: Túbulos seminíferos de Triatoma maculata submetidos à técnica de bandamento-C. (a) Núcleo poliplóide com um corpúsculo fragmentado e heterocromático (seta). (b) Metáfase espermatogonial com um dos cromossomos sexuais totalmente heterocromático (seta). (c-f) Estágio difuso. (g) Metáfase II. (h) Espermátide inicial. (i) Espermátide em alongamento com uma bainha heterocromática (seta). (j) Espermatozóide. 


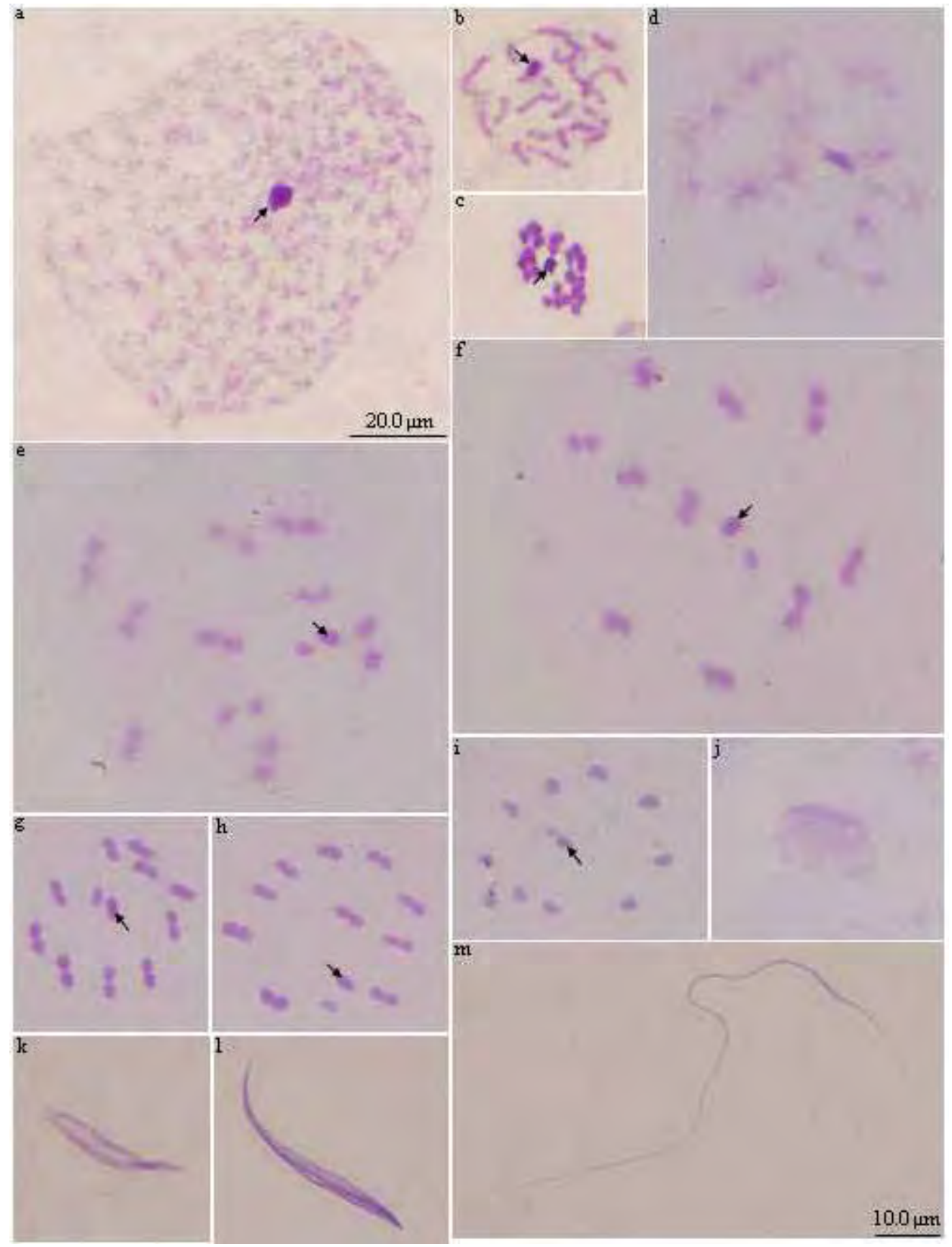

Figura 9: Túbulos seminíferos de Triatoma pseudomaculata submetidos à técnica de bandamento-C. (a) Núcleos poliplóides. A seta indica um corpúsculo heterocromático. (b) Prometáfase mitotica com um corpúsculo heterocromático (seta). (c) Metáfase mitótica com um cromossomo heterocromático (seta). (d) Estágio difuso. (e-i) Metáfases meióticas. As setas indicam o cromossomo $Y$ heterocromático. (j) Espermátide inicial. (k-l) Espermátide em alongamento. (m) Espermatozóide. 


\subsubsection{Reação de Feulgen}

\subsubsection{Espermatogênese em Triatoma maculata}

Os resultados obtidos no presente trabalho, utilizando a técnica de esmagamento dos testículos de T. maculata e posterior coloração pela reação de Feulgen, forneceram os seguintes dados:

Os núcleos poliplóides da parede do túbulo seminífero apresentaram-se fracamente corados pelo reativo de Schiff, porém, na região central pode-se observar um corpúsculo mais fortemente evidenciado (Figura 10a). Os núcleos interfásicos das células espermatogoniais mostraram-se fortemente marcados, com um corpúsculo periférico mais evidente (Figura 10b). Nos núcleos em prófase das espermatogônias foi possível verificar o início da condensação dos cromossomos mitóticos (Figura 10c). Durante esta fase o núcleo se mostrou fracamente corado.

As metáfases espermatogoniais exibiram os 22 cromossomos igualmente corados. Nesta fase não há uma orientação específica para os cromossomos, porém, nota-se a presença de diminutos filamentos unindo alguns cromossomos (Figura 10d).

Os espermatócitos, no início da prófase I meiótica, apresentaram uma nítida região mais fortemente marcada (Figura 10e). Nos núcleos em condensação dos estágios difuso verificou-se dois corpúsculos marcados, evidenciando assim os cromossomos sexuais individualizados (Figura 10f-k). Foi observado que, ao longo da condensação, um destes cromossomos se mostrou mais fortemente corado (Figura 10f-i, setas). Ainda, durante o estágio difuso, foi possível acompanhar a organização dos cromossomos para a fase seguinte (Figura 101-n).

As metáfases da segunda divisão meiótica, vistas frontalmente, apresentaram os 10 cromossomos autossomos dispostos em forma de círculos ao redor dos dois cromossomos sexuais (XY). Pode-se verificar, também, que alguns cromossomos se mostraram mais fortemente corados (Figura 10o).

As anáfases analisadas (Figura 10p) não evidenciaram a presença de cromossomos retardatários, tampouco, as telófases (Figura 10q). Ao término das telófases, foram originadas espermátides inicialmente arredondadas e fracamente marcadas pela técnica de reação de Feulgen, porém foi possível constatar uma tênue marcação periférica (Figura 10r). No decorrer da espermiogênese, as espermátides 
sofreram progressivamente um alongamento (Figura 10s) e mostraram-se completamente coradas pelo reativo de Schiff.

\subsubsection{Espermatogênese em Triatoma pseudomaculata}

A análise dos testículos de T. pseudomaculata submetidos à reação de Feulgen revelou que os núcleos poliplóides das células nutritivas da parede dos túbulos seminíferos mostraram-se fortemente corados, com uma única marcação evidente (Figura 11a).

Os núcleos espermatogoniais em intérfase apresentaram apenas um corpúsculo localizado próximo à periferia da célula (Figura 11b). Enquanto que as espermatogônias, em prófase, responderam à esta técnica revelando o início da condensação (Figura 11c). As metáfases espermatogoniais mostraram-se sem um arranjo característico, com os cromossomos ocupando toda a placa equatorial (Figura 11d).

Os espermatócitos possuíram apenas um corpúsculo marcado pelo reativo de Schiff (Figura 11e). Corpúsculos semelhantes foram observados no início da prófase I meiótica (Figura 11f). Durante os diferentes estágios de condensação da cromatina nos núcleos em estágio difuso (Figura 11g-j), foi possível notar a existência de dois corpúsculos formados pelos cromossomos sexuais individualizados. Em algumas células, o maior destes corpúsculos mostrou-se mais fortemente corado em relação ao outro (Figura 11g-h). No final desta fase, foi verificado o início da metáfase I (Figura $11 \mathrm{k})$.

As metáfases I da meiose apresentaram 10 autossomos dispostos na placa metafásica em formato circular com os dois cromossomos sexuais ao centro deste (Figura 111). Os cromossomos meióticos apresentaram-se sempre corados com a mesma intensidade, o mesmo foi verificado nas metáfases I lateral (Figura 11m).

Nas anáfases meióticas, os cromossomos apresentaram-se migrando para os pólos da célula, até atingir o estágio de telófase (Figura 11o). No processo de espermiogênese, as espermátides iniciais foram fracamente coradas, sendo possível distinguir apenas algumas marcações periféricas (Figura 11p) e as espermátides alongadas apresentaram a região anterior um pouco mais corada (Figura 11q). 


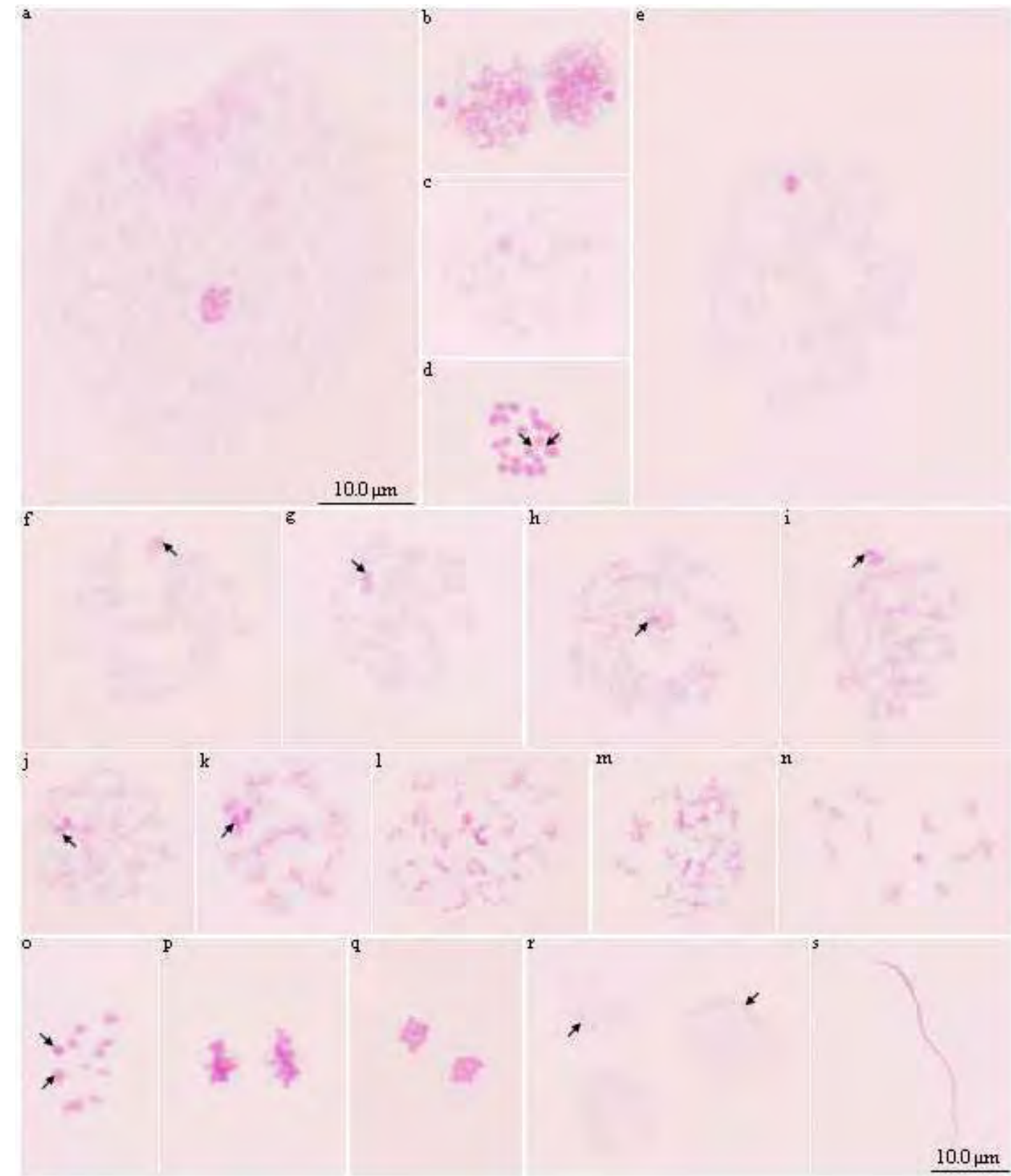

Figura 10: Túbulos seminíferos de T. maculata submetidos à reação de Feulgen. (a) Núcleo poliplóide mostrando apenas um corpúsculo localizado na região central fortemente marcado pelo reativo de Schiff. (b) Núcleos interfásicos das células espermatogoniais com uma única marcação periférica. (c) Núcleos da célula espermatogonial, pouco corado, em prófase evidenciando o início da condensação dos cromossomos mitóticos. (d) Metáfase espermatogonial apresentando 22 cromossomos. Observar a presença de filamentos unindo alguns cromossomos (setas). (e) Espermatócito com apenas um corpúsculo corado. (f-k) Núcleos da prófase I meiótica apresentando dois corpúsculos marcados, evidenciando assim os cromossomos sexuais individualizados. Observar um dos cromossomos mais fortemente corado (setas). (1-n) Estágios finais da prófase I. (o) Metáfase meiótica da segunda divisão. Notar alguns cromossomos mais fortemente corados (setas). (p) Anáfase meiótica. (q) Telófase. (r) Espermátides iniciais fracamente coradas, apresentando uma tênue marcação periférica (setas). (s) Espermátide em alongamento final mostrando-se completamente corada. 


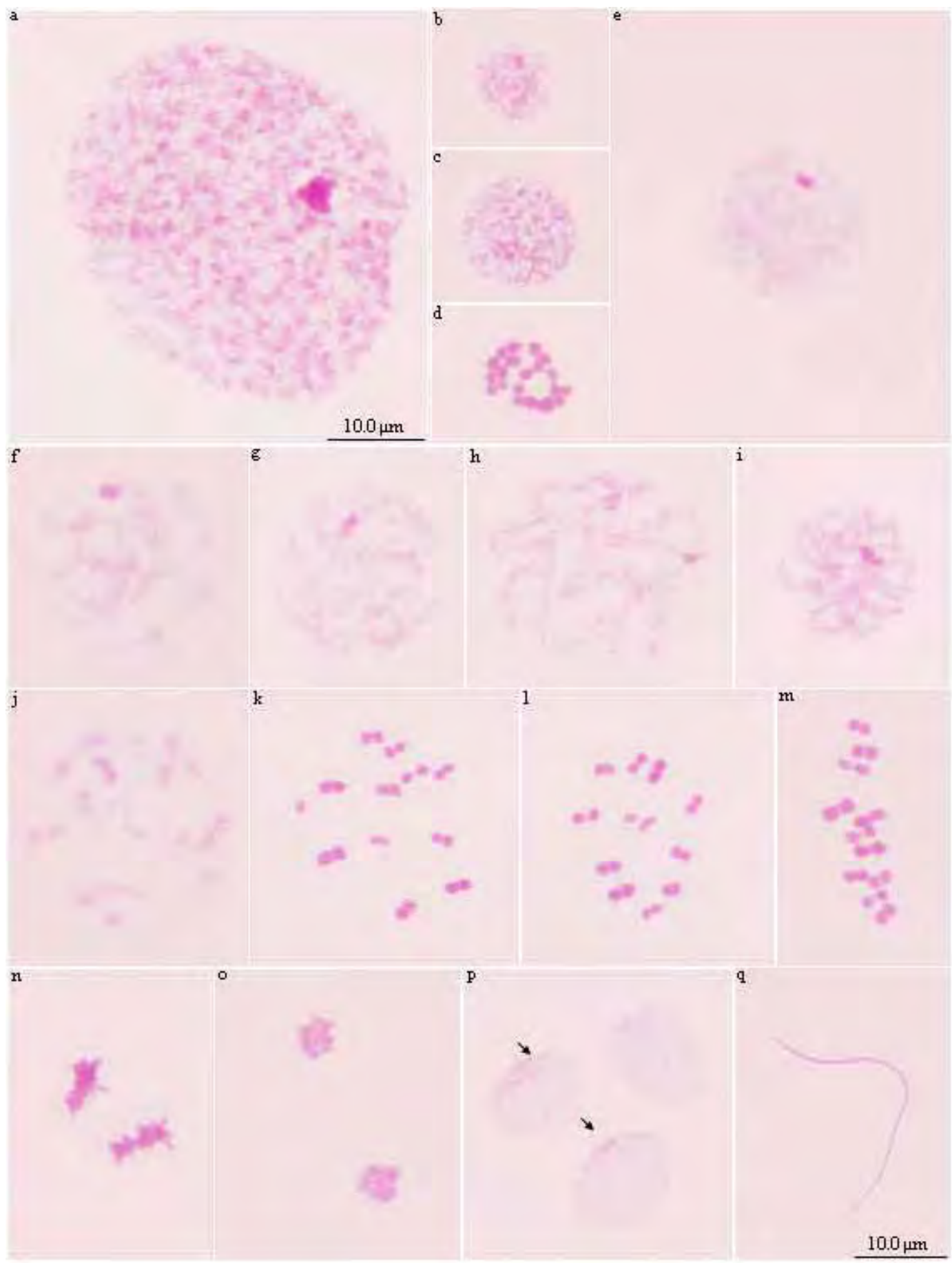

Figura 11: Túbulos seminíferos de T. pseudomaculata submetidos à técnica de Reação de Feulgen. (a) Núcleo poliplóide. (b) Núcleo da célula espermatogonial em intérfase. (c) Núcleo da célula espermatogonial em prófase em início da condensação. (d) Metáfase espermatogonial. (e) Espermatócito com apenas uma marcação. (f) Início da prófase I da meiose com um corpúsculo. (g-j) Prófase I da meiose em diferentes estágios de condensação da cromatina, com dois corpúsculos formados pelos cromossomos sexuais individualizados. (k) Início da metáfase I. (l) Metáfase da primeira divisão meiótica circular com os cromossomos sexuais no centro do anel formado pelos autossomos. Notar a coloração homogênea dos cromossomos. (m) Metáfase I lateral. (n) Anáfase meiótica. (o) Telófase. (p) Espermátides iniciais fracamente coradas, com algumas marcações periféricas (setas). (q) Espermátide final. 


\subsection{Técnica de citogenética molecular}

\subsubsection{Bandamento-C CMA/DAPI}

A técnica de bandamento-C descrita por Sumner (1972) é uma das técnicas mais simples capaz de detectar somente a heterocromatina constitutiva em células interfásicas e em cromossomos metafásicos. Porém, atualmente, outras técnicas para se obter bandas diferenciais vêm sendo aplicadas; é o caso da utilização de corantes fluorescentes, ou fluorocromos no bandamento-C CMA/DAPI (MORIELLE, 2004). O fluorocromo 4'-6 diamidino-2-fenilindole (DAPI) cora preferencialmente a heterocromatina rica em adenina e timina, enquanto que a cromomicina $\left(\mathrm{CMA}_{3}\right)$ cora regiões da heterocromatina ricas em citosina e guanina (SCHWEIZER, 1976; SUMNER, 1982; GUERRA, 2000).

O estudo comparativo foi realizado analisando-se células em início de metáfases I e II dos túbulos seminíferos de T. maculata e T. pseudomaculata (Figuras 12 e 13). Estes mesmos resultados foram observados em imagens capturadas em escala de cinza (Figuras 14 e 15). Essa imagem também possibilita visualização do padrão de marcação destes fluorocromos.

Por meio da técnica de bandamento-C CMA/DAPI foi possível identificar as regiões de heterocromatina nos cromossomos e a sua composição de bases pôde ser diferenciada com a aplicação dos fluorocromos (CMA/DAPI). O fluorocromo fluorocromo 4'-6 diamidino-2-fenilindole (DAPI) é destacado em azul e cora a heterocromatina rica em adenina e timina (AT), enquanto que a cromomicina $\left(\mathrm{CMA}_{3}\right)$, que apresenta coloração verde, evidencia regiões ricas em citosina e guanina (CG).

Em ambas as espécies analisadas, a técnica permitiu a caracterização da heterocromatina presente em um dos cromossomos sexuais (Y). Este cromossomo se mostrou rico em bases AT ( $\left.\mathrm{DAPI}^{+}\right)$e com ausência de bases $\mathrm{CG}\left(\mathrm{CMA}^{-}\right)$, confirmando assim a natureza heterocromática deste cromossomo, observada inicialmente por meio da técnica de bandamento-C. Na espécie T. pseudomaculata também pode-se verificar uma marcação DAPI ${ }^{+}$bem evidente nos espermatócitos (Figura 13, c). 


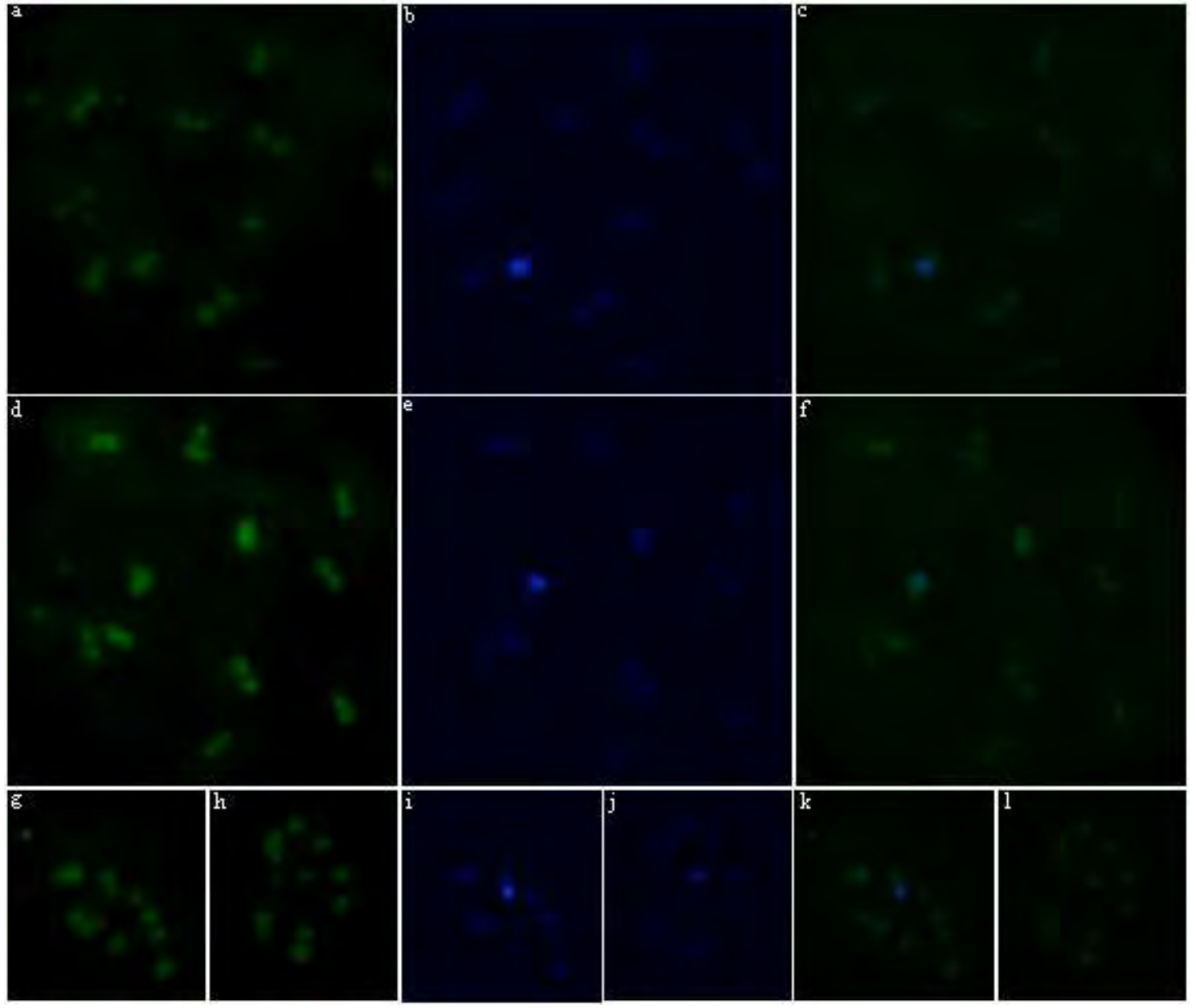

Figura 12: Túbulos seminíferos de T. maculata submetidos à técnica de bandamento-C CMA/DAPI. (a, d, g-h) Metáfases meióticas coradas pelo fluorocromo CMA, indicando a ausência de heterocromatina rica em bases CG (CMA $)$. (b, e, i-j) Metáfases meióticas coradas pelo fluorocromo DAPI, mostrando um dos cromossomos sexuais com heterocromatina rica em bases $\mathrm{AT}\left(\mathrm{DAPI}^{+}\right)$. (c, f, k-1) Sobreposição das mesmas metáfases evidenciadas pelos fluorocromos CMA/DAPI. 


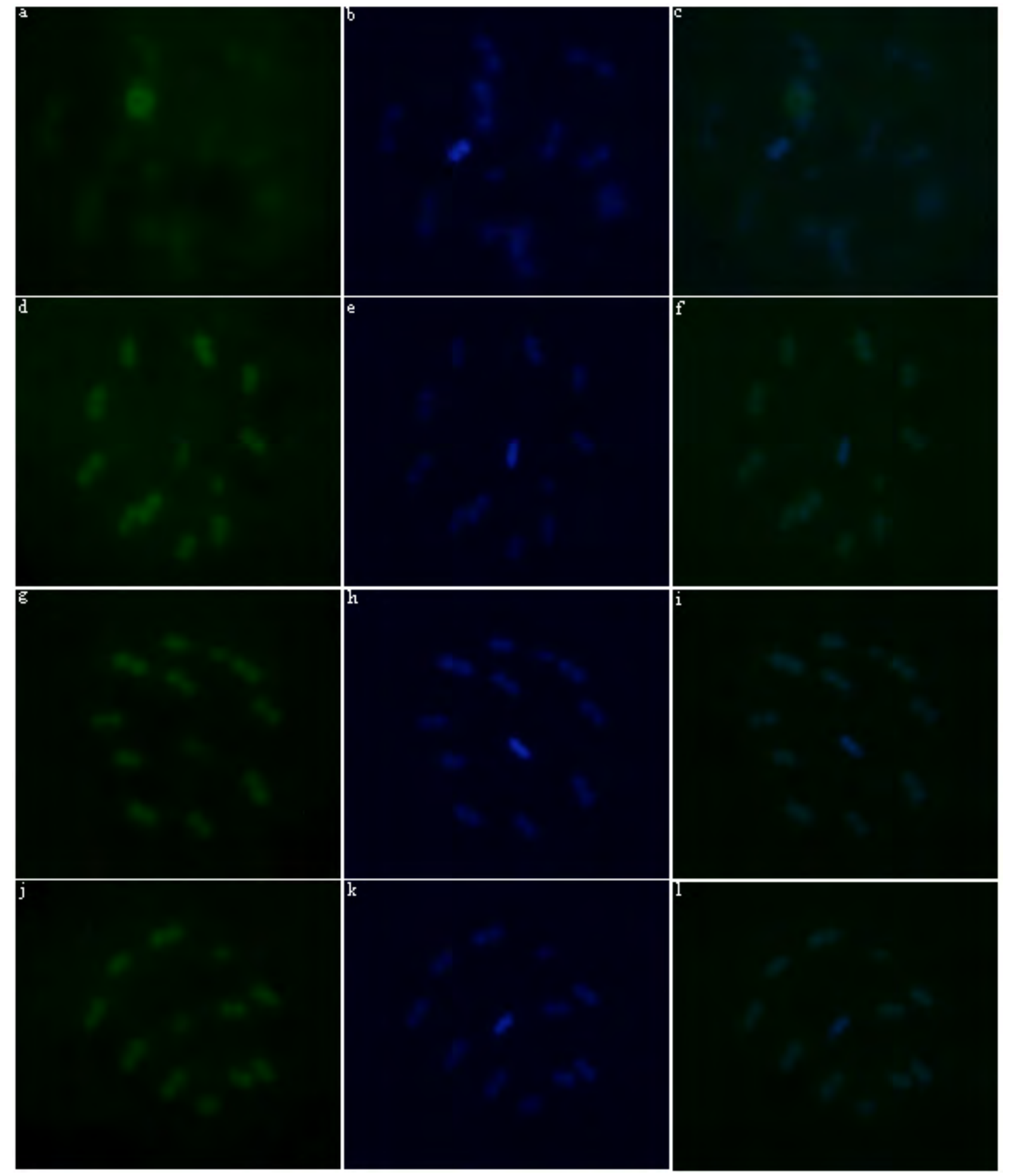

Figura 13: Túbulos seminíferos de $T$. pseudomaculata submetidos à técnica de bandamento-C CMA/DAPI. (a, d, g, j) Metáfases meióticas coradas pelo fluorocromo CMA, indicando a ausência de heterocromatina rica em bases $\mathrm{CG}\left(\mathrm{CMA}^{-}\right)$. (b, e, h, k) Metáfases meióticas coradas pelo fluorocromo DAPI, mostrando um dos cromossomos sexuais com heterocromatina rica em bases AT $\left(\mathrm{DAPI}^{+}\right)$. (c, f, i, l) Sobreposição das mesma metáfases evidenciadas pelos fluorocromos CMA/DAPI. 


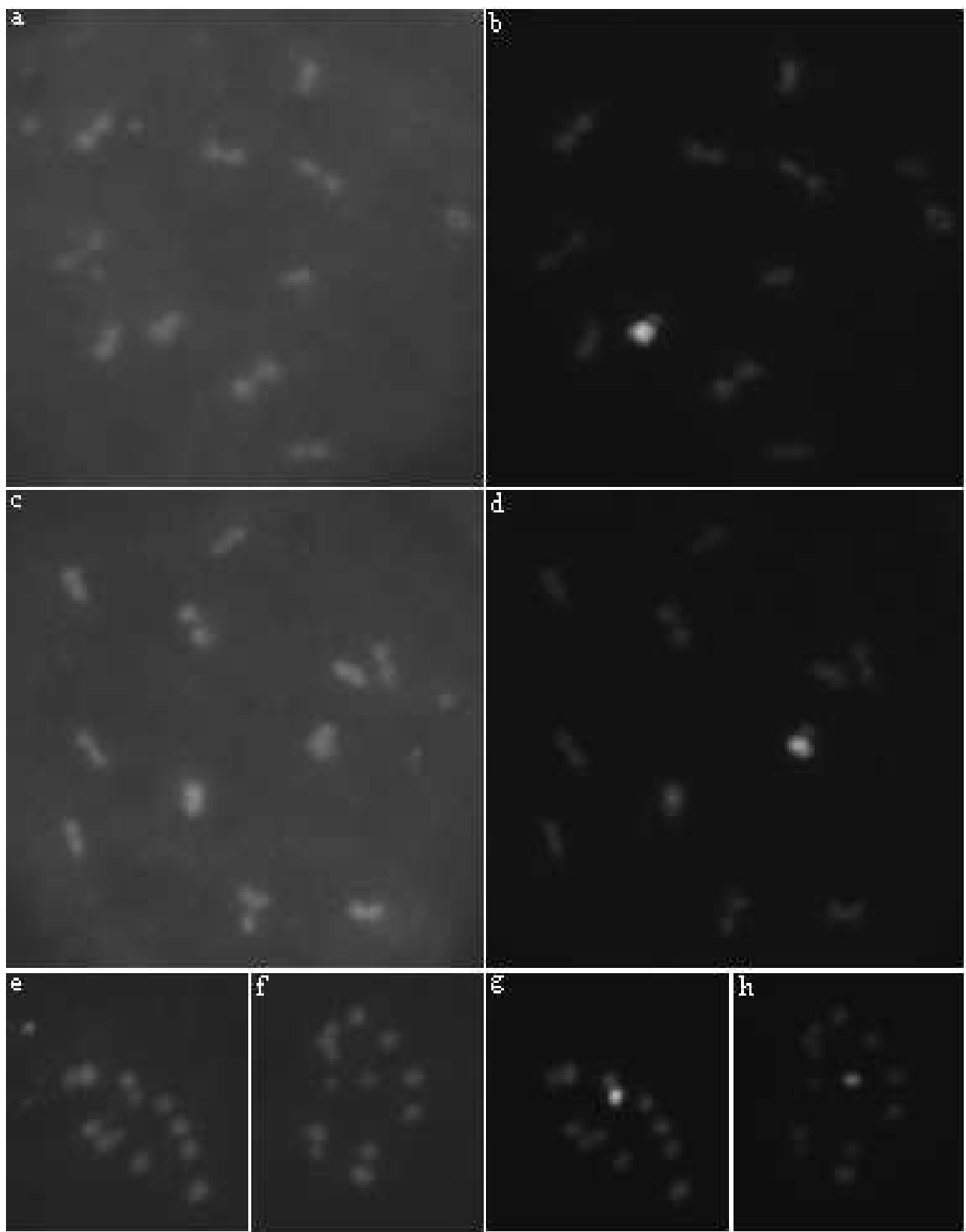

Figura 14: Túbulos seminíferos de T. maculata submetidos à técnica de bandamento-C CMA/DAPI (imagens capturadas em escala de cinza). (a, c, e, f) Metáfases meióticas coradas pelo fluorocromo CMA, indicando a ausência de heterocromatina rica em bases $\mathrm{CG}\left(\mathrm{CMA}^{-}\right)$. (b, d, g, h) Metáfases meióticas coradas pelo fluorocromo DAPI, mostrando um dos cromossomos sexuais com heterocromatina rica em bases AT $\left(\mathrm{DAPI}^{+}\right)$. 


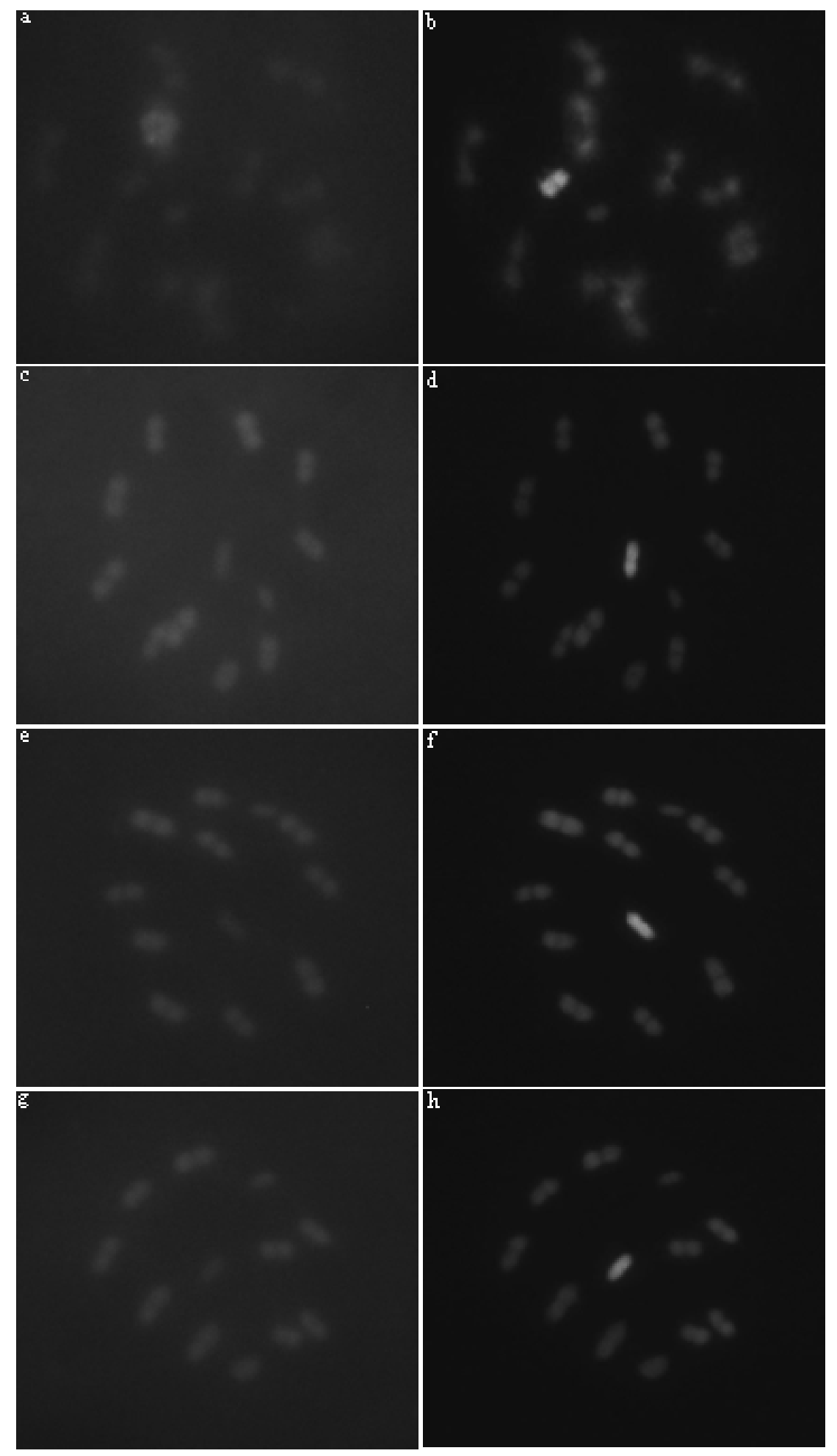

Figura 15: Túbulos seminíferos de $T$. pseudomaculata submetidos à técnica de bandamento-C CMA/DAPI (imagens capturadas em escala de cinza). (a, c, e, g) Metáfases meióticas coradas pelo fluorocromo CMA, indicando a ausência de heterocromatina rica em bases $\mathrm{CG}\left(\mathrm{CMA}^{-}\right)$. ( $\left.\mathrm{b}, \mathrm{d}, \mathrm{f}, \mathrm{h}\right)$ Metáfases meióticas coradas pelo fluorocromo DAPI, mostrando um dos cromossomos sexuais DAPI'. 
No quadro I encontram-se resumidos os principais resultados oriundos da análise das lâminas dos túbulos seminíferos, submetidos às técnicas citogenéticas convencionais (orceína lacto-acética; impregnação por íons prata; bandamento-C; reação de Feulgen) e à técnica de citogenética molecular (bandamento-C CMA/DAPI), das duas espécies (T.maculata e T. pseudomaculata) estudadas no presente trabalho.

Quadro 1: Resumo das principais características citogenéticas da espermatogênese de Triatoma maculata e Triatoma pseudomaculata, com base na análise dos túbulos seminíferos submetidos às técnicas de citogenética convencional (orceína lacto-acética, impregnação por íons prata, bandamento-C e reação de Feulgen) e à técnica de citogenética molecular (bandamento-C CMA/DAPI).

\begin{tabular}{|c|c|c|}
\hline & Triatoma maculata & Triatoma pseudomaculata \\
\hline Cariótipo & $2 n=20 A+X Y$ & $2 n=20 A+X Y$ \\
\hline \multicolumn{3}{|c|}{ Orceína lacto-acética } \\
\hline Núcleo poliplóide & $\begin{array}{l}\text { Um único corpúsculo } \\
\text { heteropicnótico }\end{array}$ & Idem \\
\hline $\begin{array}{l}\text { Núcleos interfásicos das células } \\
\text { espermatogoniais }\end{array}$ & $\begin{array}{l}\text { Um único corpúsculo } \\
\text { heteropicnótico e nucleolar }\end{array}$ & Idem \\
\hline Estágio difuso inicial & $\begin{array}{l}\text { Corpúsculo heteropicnótico } \\
\text { bipartido }\end{array}$ & Idem \\
\hline Estágio difuso final & $\begin{array}{l}\text { Um único } \\
\text { heteropicnótico }\end{array}$ & Idem \\
\hline Tamanho dos cromossomos & $\begin{array}{l}\text { Cromossomos sexuais menores } \\
\text { que os autossomos, sendo o } \\
\text { cromossomo Y maior que o X; } \\
\text { Autossomos: apenas um par } \\
\text { maior que os demais }\end{array}$ & $\begin{array}{l}\text { Cromossomos sexuais menores } \\
\text { que os autossomos, sendo o } \\
\text { cromossomo Y maior que o X; } \\
\text { Autossomos: de um a três } \\
\text { pares maiores que os demais } \\
\text { (PÉREZ et al., 1992) }\end{array}$ \\
\hline $\begin{array}{l}\text { Disposição dos cromossomos } \\
\text { (metáfase I e II) }\end{array}$ & $\begin{array}{l}\text { Cromossomos sexuais dispostos } \\
\text { no centro do anel formado pelos } \\
\text { autossomos }\end{array}$ & Idem \\
\hline Grau de picnose & $\begin{array}{l}\text { Apenas cromossomo } \mathrm{Y} \\
\text { heteropicnótico }\end{array}$ & Idem \\
\hline Migração tardia & Ausente & Presente \\
\hline \multicolumn{3}{|c|}{ Impregnação por íons prata } \\
\hline Núcleos poliplóides & $\begin{array}{l}\text { Dois tipos distintos: núcleo } \\
\text { poliplóide } \\
\text { impregnado e com diversos } \\
\text { corpúsculos nucleolares, sem } \\
\text { uma única marcação definida; } \\
\text { núcleo poliplóide com apenas } \\
\text { uma marcação maior e mais } \\
\text { evidente }\end{array}$ & $\begin{array}{l}\text { Uma única marcação bem } \\
\text { evidente }\end{array}$ \\
\hline Metáfases espermatogoniais & $\begin{array}{l}\text { Pequenas marcações } \\
\text { cromossomos mitóticos }\end{array}$ & Nenhuma marcação nítida \\
\hline
\end{tabular}




\begin{tabular}{|c|c|c|}
\hline Estágio difuso inicial & Marcações nucleolares tênues & Uma única marcação \\
\hline Estágio difuso final & $\begin{array}{l}\text { Não foi observado nenhuma } \\
\text { marcação }\end{array}$ & Fragmentação nucleolar \\
\hline $\begin{array}{c}\text { Desorganização e fragmentação } \\
\text { nucleolar }\end{array}$ & Prófase I (estágio difuso final) & Prófase I (estágio difuso final) \\
\hline Metáfases I e II & $\begin{array}{l}\text { Ausência de marcação nucleolar } \\
\text { e corpúsculos nucleolares; } \\
\text { cromossomos apresentaram } \\
\text { intensidades semelhantes pela } \\
\text { impregnação dos íons prata }\end{array}$ & $\begin{array}{l}\text { Algumas marcações nos } \\
\text { cromossomos, sendo bem } \\
\text { evidente a presença de uma } \\
\text { marcação em um dos } \\
\text { autossomos durante a metáfase } \\
\text { II; cromossomos sexuais } \\
\text { fortemente impregnados pela } \\
\text { prata; persistência nucleolar }\end{array}$ \\
\hline Espermátide (inicial) & Corpúsculo nucleolar & Idem \\
\hline Espermátide (final) & $\begin{array}{l}\text { Marcação argenofílica no início } \\
\text { da peça intermediária }\end{array}$ & Idem \\
\hline \multicolumn{3}{|c|}{ Bandamento-C } \\
\hline Núcleo poliplóide & $\begin{array}{l}\text { Um único corpúsculo } \\
\text { heterocromático fragmentado }\end{array}$ & $\begin{array}{l}\text { Um único } \quad \text { corpúsculo } \\
\text { heterocromático e algumas } \\
\text { regiões heterocromáticas } \\
\text { dispersas pela célula }\end{array}$ \\
\hline Metáfase mitótica e meióticas & $\begin{array}{l}\text { Um cromossomo totalmente } \\
\text { heterocromático }\end{array}$ & Idem \\
\hline \multicolumn{3}{|c|}{ Bandamento-C CMA/DAPI } \\
\hline Regiões de heterocromatina & $\begin{array}{l}\text { Apenas cromossomo } \mathrm{Y} \\
\text { heteropicnótico, rico em bases } \\
\text { AT }\left(\mathrm{DAPI}^{+}\right)\end{array}$ & Idem \\
\hline \multicolumn{3}{|c|}{ Reação de Feulgen } \\
\hline Núcleos poliplóides & $\begin{array}{l}\text { Fracamente corados, com uma } \\
\text { única marcação evidente }\end{array}$ & Idem \\
\hline Metáfases espermatogoniais & $\begin{array}{l}\text { Presença de filamentos } \\
\text { cromossômicos }\end{array}$ & $\begin{array}{l}\text { Ausência de filamentos } \\
\text { cromossômicos }\end{array}$ \\
\hline Estágio difuso & $\begin{array}{l}\text { Presença de dois corpúsculos, } \\
\text { provavelmente formado pelos } \\
\text { cromossomos sexuais, sendo o } \\
\text { maior mais fortemente corado }\end{array}$ & Idem \\
\hline Metáfases meióticas & $\begin{array}{lcr}\text { Presença } & \text { de } & \text { alguns } \\
\text { cromossomos } & \text { mais } & \text { fortemente } \\
\text { corados } & & \\
\end{array}$ & \begin{tabular}{lcrr} 
Todos os & \multicolumn{2}{c}{ cromossomos } \\
corados com & a & mesma \\
intensidade & & & \\
\end{tabular} \\
\hline Espermátides & Fracamente marcadas & Idem \\
\hline
\end{tabular}




\subsection{Técnicas moleculares}

\subsubsection{Seqüienciamento e Alinhamento da Região ITS-1 do DNA Ribossômico}

O fragmento de DNA purificado foi enviado ao Centro de Estudos do Genoma Humano (CEGH), ligado ao Instituto de Biociências da USP - Universidade de São Paulo para seqüenciamento, tendo sido realizados dois seqüenciamentos Foward e dois seqüenciamentos Reverse para cada espécie. A comparação das sequências analisadas mostrou que essa região intergência apresenta sequências de tamanho em torno de 700 pb para a espécie T. maculata, enquanto que a espécie $T$. pseudomaculata apresentou um fragmento amplificado para a região ITS-1 de cerca de 750 pb. A partir destas sequências, foi criada uma sequência consenso final e, então, as espécies foram alinhadas pelo programa BioEdit Sequence Alignment Editor V. 7.0.5 (HALL, 1999), e uma matriz de identidade foi gerada para estas regiões (Quadro 2).

Quadro 2: Matriz de identidade gerada pelo software BioEdit Sequence Alignment

\section{Matriz de Identidade}

$\begin{array}{lcc}\text { Sequência } & \text { T. maculata } & \text { T. pseudomaculata } \\ \text { T. } \text { maculata } & \text { ID } & 0,985 \\ \text { T. pseudomaculata } & 0,985 & \text { ID }\end{array}$

Finalmente, foi elaborada uma sequência consenso entre as duas espécies analisadas com a finalidade de verificar em que posições ocorreram as divergências de nucleotídeos. As divergências ocorreram nas posições 671, 673, 674, 675 e 688 (Figura 16).

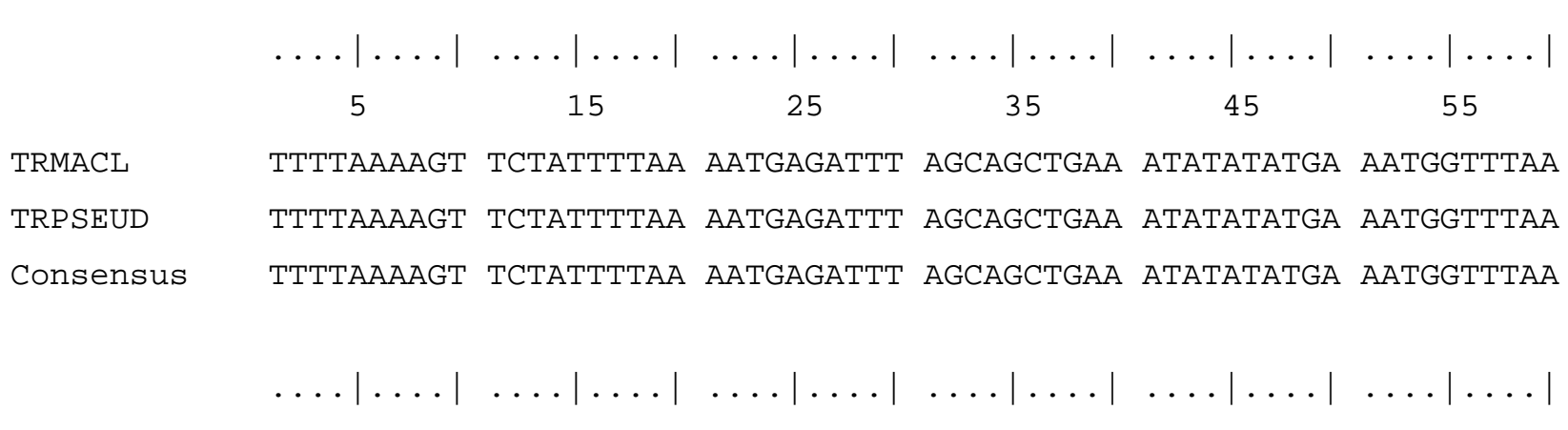


65

75

85

95

105

115

TRMACL

TRPSEUD

Consensus

TRPSEUD

Consensus

TRMACI

TRP SEUD

Consensus

TRMACL

TRP SEUD

Consensus

TRMACL

TRPSEUD

Consensus

TRPSEUD

Consensus

TRMACI

TRP SEUD

Consensus

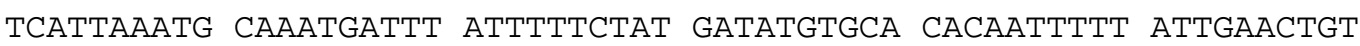

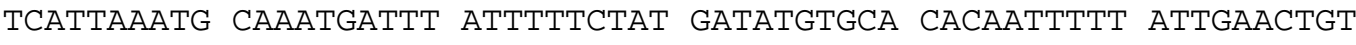

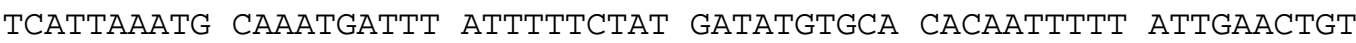

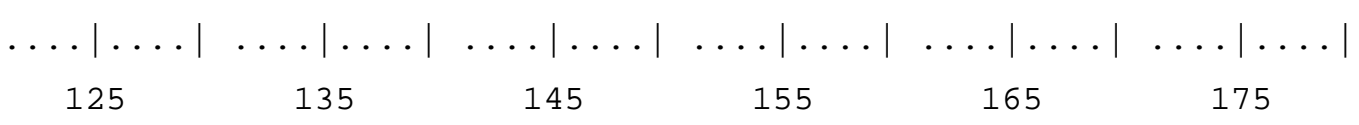

TAGGGGTGAA AGACCATAAA TAAAAACCGC AAAGACAAAT GAAATGAACT GACTGTTGTA TAGGGGTGAA AGACCATAAA TAAAAACCGC AAAGACAAAT GAAATGAACT GACTGTTGTA TAGGGGTGAA AGACCATAAA TAAAAACCGC AAAGACAAAT GAAATGAACT GACTGTTGTA

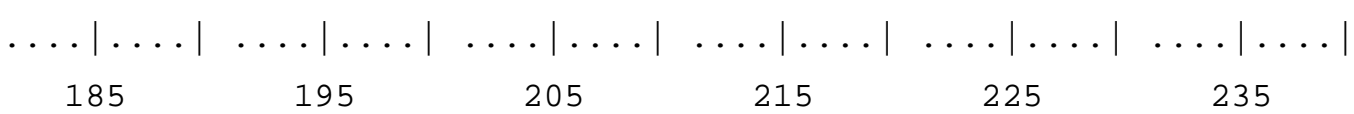
CCAATACTAG TATACTGACT GTTGTACAAA TACT-AgtAT ATACATCTAT CCAATAAATG CCAATACTAG TATACTGACT GTTGTACAAA tACTtAgtAT ATACATCTAT CCAATAAATG CCAATACTAG TATACTGACT GTTGTACAAA tACtTAgtAT AtACATCtAT CCAAtAAAtg

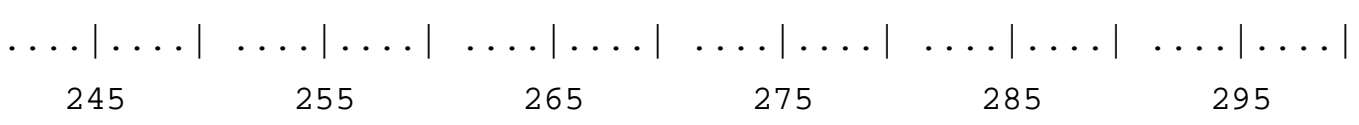
tgGAtAtAgC CGCCGTAtCT ACAgGAtAgA tACAtCAtGT GGACtTGgGA CACCCACATG TGGAtATAGC CGCCGTATCT ACAgGATAgA TACATCATGT GGACTTGgGA CACCCACATG TGGAtAtAgC CGCCGTAtCT ACAgGAtAgA tACAtCAtGT GGACtTGGGA CACCCACATG

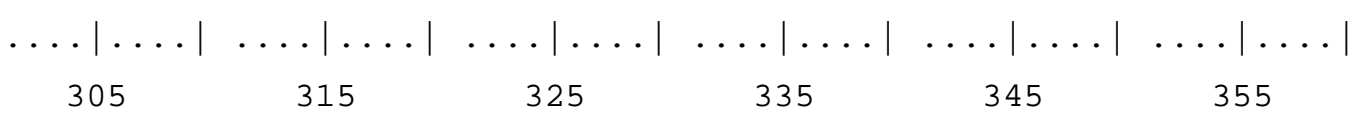
AtgAtACATG TGGACTTGGg GAACCCACAT GATGGACGCG CTTATGTGAA ACCATGGAAG ATGATACATG TGGACTTGGg GAACCCACAT GATGGACGCG CTTATGTGAA ACCATGGAAG

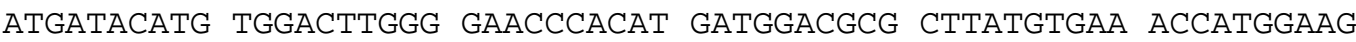

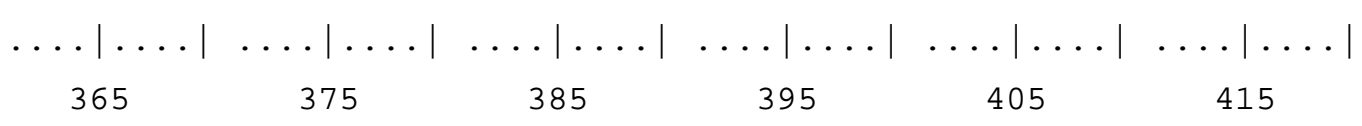

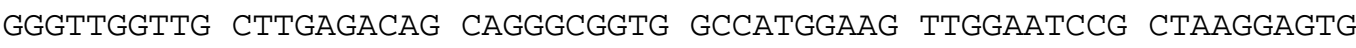

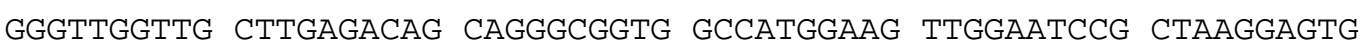

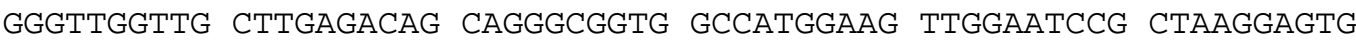

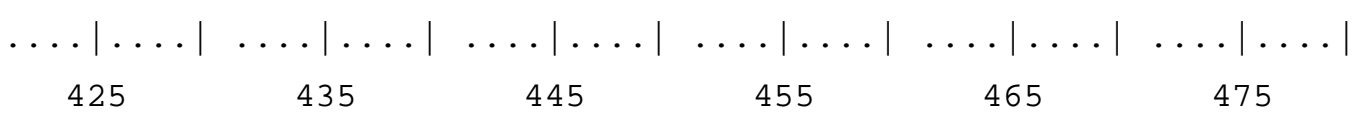
TGTAACAACT CACCTGCCGA GgCAACTAGC ACTGGAAATG GATGtAACTA TAGCGTTGgG TGTAACAACT CACCTGCCGA GGCAACTAGC ACTGgAAATG GATGTAACTA TAGCGTtGgG TGTAACAACT CACCTGCCGA GGCAACTAGC ACTGGAAATG GATGTAACTA TAGCGTTGGG 


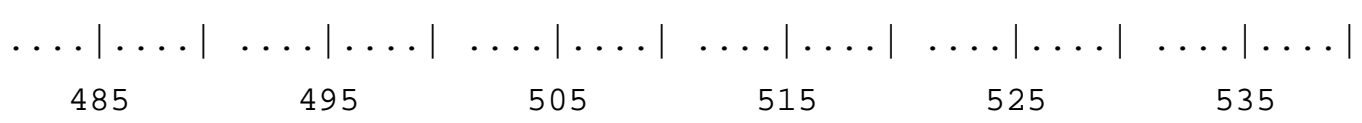

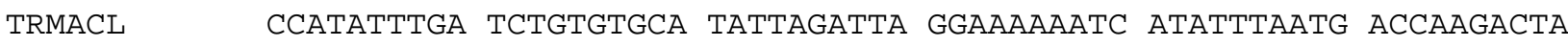

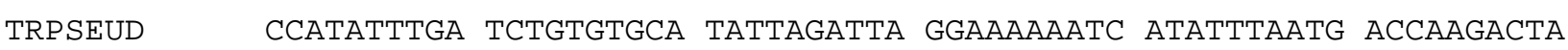

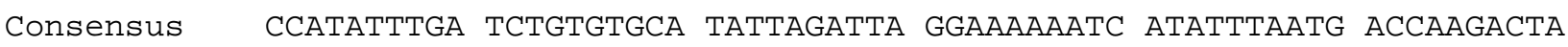

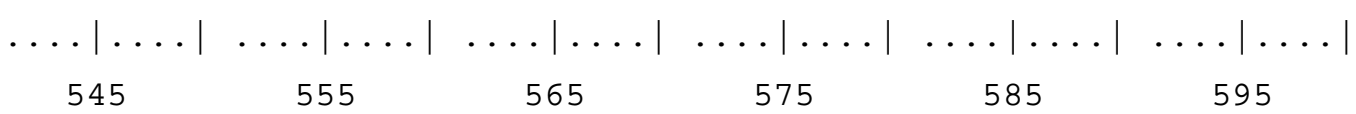

TRMACL

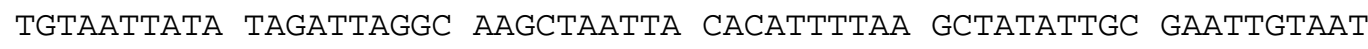
TRPSEUD

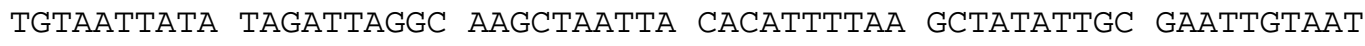
Consensus

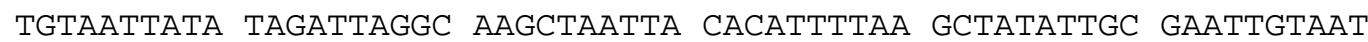

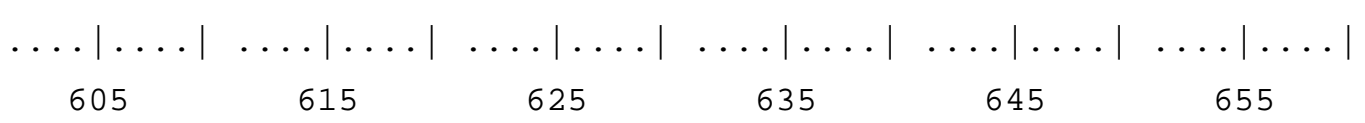

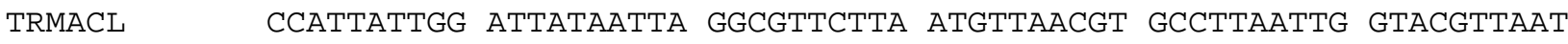

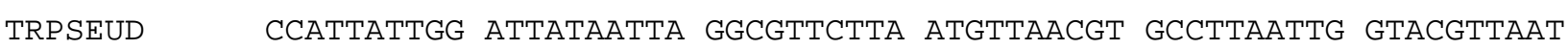
Consensus

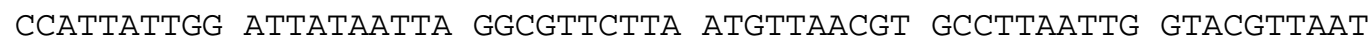

$$
\begin{aligned}
& \ldots|\ldots| \ldots|\ldots| \ldots|\ldots| \ldots|\ldots| \ldots|\ldots| \ldots|\ldots| \ldots \mid \\
& \begin{array}{lllll}
665 & 675 & 685 & 695 & 705
\end{array}
\end{aligned}
$$

TRMACL

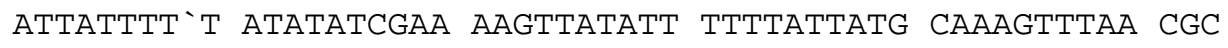
TRPSEUD Attatttiat tttattcGAa Aagttattit ttttattatg CAAagtttaA CGC Consensus

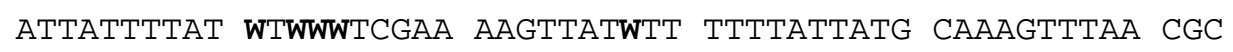

Figura 16: Alinhamento das sequências da região ITS-1 das espécies estudadas $T$. maculata (TRMACL) e T.pseudomaculata (TRPSEUD), e a sequência consenso gerada pelo programa BioEdit Sequence Alignment. 


\section{DISCUSSÃO}

\subsection{Técnicas citogenéticas}

No presente trabalho, foi realizado o estudo da espermatogênese, da estrutura cromossômica e do ciclo nucleolar de Triatoma maculata e Triatoma pseudomaculata, utilizando-se as técnicas citogenéticas de orceína lacto-acética, impregnação por íons prata, bandamento-C, reação de Feulgen e bandamento-C CMA/DAPI.

No Brasil, as análises citogenéticas de triatomíneos foram iniciadas quando Schreiber e Pellegrino (1948) estudaram o cariótipo de onze espécies. Desde então, estudos citogenéticos com esses vetores têm sido concentrados em técnicas convencionais de coloração cromossômica (SCHREIBER; PELLEGRINO, 1951; UESHIMA, 1966; SOLARI, 1979; PANZERA et al., 1995; SEVERI-AGUIAR; AZEREDO-OLIVEIRA, 2005; BARDELLA et al., 2008).

Nas espécies estudadas foi verificado que os seus cromossomos comportam-se como holocêntricos, característica presente na ordem Heteroptera, descrita por Schrader (1935) e Hughes-Scharader e Scharader (1961). Além dessa ordem, outros organismos como protozoários, algas, plantas (Cyperaceae e Juncaceae), e alguns insetos das ordens Homoptera, Lepidoptera e Trichoptera também apresentam cromossomos holocêntricos (GUERRA, 1988; WOLF, 1996). Nesses cromossomos, os microtúbulos do fuso interagem com a maior parte do comprimento da cromátide, não apresentando, desta forma, uma constrição primária. Como resultado, durante a divisão celular, os cromossomos dispõem-se perpendiculares ao fuso no momento da migração para os pólos na anáfase, não formando a tradicional figura na forma de "V" observada na divisão celular dos cromossomos monocêntricos (SEVERI-AGUIAR, 2001).

Além disso, a maioria das espécies que possuem cromossomos holocêntricos também apresenta um modelo de meiose incomum, no qual a segregação dos cromossomos sexuais é pós-reducional (SCHREIBER; PELLEGRINO, 1951; BARTH, 1956; UESHIMA, 1966; SOLARI, 1979). Nesses organismos, durante a anáfase I, os cromossomos sexuais são pré-equacionais e, na anáfase II, apresentam-se pósreducionais. Entretanto, existem algumas exceções, como por exemplo, indivíduos pertencentes à família Tingidae (Heteroptera), ao gênero Anisops (Notonectidae), à espécie Ectrychotes dispar (Reduviidae), a quatro espécies de dois gêneros de Coreidae, 
os quais apresentam meiose pré-reducional nos cromossomos sexuais (GROZEVA et al., 2006).

Por estes motivos, as espécies que apresentam cromossomos holocêntricos são tratadas como casos excepcionais na citogenética. Assim, como estes organismos, os triatomíneos também podem ser considerados de importante interesse citogenético, além de sua importância como vetor da doença de Chagas (SEVERI-AGUIAR, 2001).

O conhecimento citogenético de triatomíneos está baseado em técnicas de coloração convencionais dos cromossomos (SCHREIBER; PELLEGRINO, 1951; BARTH, 1956; UESHIMA, 1966). Uma dessas técnicas convencionais é a coloração pela orceína lacto-acética, que faz uma diferenciação refinada corando mais fortemente a heterocromatina e fracamente a eucromatina. Isto se deve ao fato de que a heterocromatina apresenta maior compactação e mais proteínas do que a eucromatina (AZEREDO-OLIVEIRA, 1990). O mecanismo dessa técnica compreende, de um modo simples, a ligação de moléculas do grupo amino das proteínas totais (histonas e não histonas complexadas ao DNA) com as moléculas de orceína pelo processo de acidofilia (VIDAL; MELLO, 1987). Por meio desta técnica, juntamente com dados já descritos na literatura, foi possibilitada a análise da espermatogênese das espécies estudadas, corroborando alguns aspectos interessantes sobre o comportamento cromossômico nesses insetos.

Os núcleos poliplóides das células nutritivas dos túbulos seminíferos de $T$. maculata e $T$. pseudomaculata exibiram um único corpúsculo heteropicnótico que respondeu positivamente à técnica de bandamento-C. A poliploidia dessas células reflete o grau de atividade celular e a grande demanda de produção de RNA por tais núcleos poliplóides (MELLO, 1978), indicando a alta taxa metabólica necessária para a manutenção das células em divisão (DE VAIO et al., 1985).

As análises realizadas por meio da coloração dos túbulos seminíferos com orceína lacto-acética, juntamente com os dados existentes na literatura, mostraram que o número cromossômico diplóide de T. maculata e $T$. pseudomaculata, montados com base nas metáfases espermatogoniais (mitótica), metáfases da primeira e segunda divisão meiótica, apresentou $2 \mathrm{n}=22(20 \mathrm{~A}+\mathrm{XY})$, confirmando, dessa forma, os dados citogenéticos da literatura (AZEREDO-OLIVEIRA, 1990; PÉREZ et al., 1992; CARCAVALLO et al., 1999), e coincidindo com o número modal do grupo citado na literatura (UESHIMA, 1966; PÉREZ et al., 1992). Segundo Ueshima (1966), o número cromossômico diplóide em machos adultos da subfamília Triatominae varia de 21 a 25 
cromossomos, enquanto que a maioria de seus membros apresenta 22 cromossomos (TARTAROTTI; AZEREDO-OLIVEIRA, 1999; TAVARES; AZEREDO-OLIVEIRA, 1997a).

Na família Triatominae, uma das características citogenéticas é a pequena variação no tamanho cromossômico, o que pode ser constatado nas metáfases espermatogoniais. Durante esta fase, pode-se acompanhar a condensação dos cromossomos, principalmente em T. maculata, que confirmou a presença de um par de cromossomos maior que os demais. A espécie T. pseudomaculata parece apresentar também alguns cromossomos maiores. Segundo De Vaio et al. (1985) e Pérez et al. (1992), essa espécie exibe de um a três cromossomos maiores. Dessa forma, esses insetos se associam ao grupo de espécies que exibem de um ou mais autossomos maiores no complemento cromossômico sendo, portanto, o tamanho cromossômico, uma diferença entre as duas espécies analisadas.

As células em estágio difuso inicial de ambas as espécies apresentaram um corpúsculo bipartido, formado pelos cromossomos sexuais, que puderam ser observados individualizados inicialmente, porém, ao final desta fase, os cromossomos se associam, formando um único corpúsculo.

As espécies analisadas apresentaram graus de picnose semelhantes. As duas espécies exibiram heteropicnose para os cromossomos sexuais e isopicnose para os autossomos. Essa característica é comumente observada em heterópteros durante a prófase I meiótica.

Durante as metáfases meióticas, os cromossomos holocênticos foram observados assemelhando-se a pequenas estruturas arredondadas, comportando-se de maneira semelhante aos demais cromossomos presentes em Heteroptera (UESHIMA, 1966). Neste grupo, os autossomos dispõem-se radialmente na periferia da placa metafásica e os cromossomos sexuais no centro deste anel (DE VAIO et al., 1985; PÉREZ et al., 1992). Em ambas as espécies, o cromossomo sexual maior apresentou-se mais heteropicnótico.

A identificação dos cromossomos sexuais baseia-se, normalmente, no fato do tamanho desses cromossomos estarem ligado à fragmentação do cromossomo $\mathrm{X}$ nos machos, de acordo com a hipótese mais aceita para explicar a origem dos diferentes sistemas de determinação do sexo dos múltiplos cromossomos sexuais (SCHRADER, 1947; WHITE, 1973). Aliando-se esta informação aos dados disponíveis na literatura, 
considera-se o cromossomo sexual maior sendo o Y, portanto mais heteropicnótico, e o cromossomo sexual menor como X, para ambas as espécies.

A migração tardia dos cromossomos durante a anáfase foi reportada em poucas células de T. pseudomaculata. Estudos anteriores sugerem que os cromossomos com migração tardia sejam os cromossomos sexuais, gerados em consequência da divisão equacional dos heterocromossomos (MORIELLE; AZEREDO-OLIVEIRA, 2004).

A técnica de impregnação por íons prata é também um dos métodos clássicos utilizados em citogenética, que permite a identificação das regiões organizadoras nucleolares (RONs) nos cromossomos metafásicos e a marcação nucleolar nos núcleos interfásicos (MORIELLE, 2004). O nucléolo é uma estrutura nuclear comum a todas as células eucarióticas e é responsável pela biogênese dos ribossomos que ocorre por meio de uma série de eventos envolvendo a transcrição de genes RNAr, processamento dos pré-RNAs ribossômicos e a reunião de partículas pré-ribossomais (SCHERR et al., 1997). Variações nos padrões de atividade transcricional, expressadas por diferenças no tamanho ou no número de nucléolos, podem resultar de uma redução ou ausência de DNAr, ou talvez, de um processo de regulação do gene (GALLETTI-JÚNIOR et al., 1985).

Os túbulos testiculares de T. maculata e T. pseudomaculata, submetidos à técnica de impregnação por íons prata, mostraram núcleos poliplóides homogeneamente corados ou contendo uma única marcação em T. maculata, enquanto T. pseudomaculata mostrou diversos tipos de marcações. Nos núcleos iniciais da prófase I meiótica das duas espécies, verificou-se a presença de um único corpúsculo marcado pela prata, enquanto que, em estágios mais avançados pode-se observar pequenos fragmentos espalhados pelo núcleo.

No presente estudo, não houve marcações específicas indicativas de regiões organizadoras nucleolares (RONs) nos cromossomos metafásicos meióticos de $T$. maculata, entretanto, durante as metáfases espermatogoniais, um dos cromossomos mitóticos apresentou uma pequena, porém significante marcação. Ao contrário dessa espécie, em $T$. pseudomaculata só foi possível verificar marcações nos cromossomos meióticos. É importante destacar que estas marcações foram visíveis tanto nos autossomos, como nos cromossomos sexuais que se mostraram, algumas vezes, quase que completamente impregnados pelos íons prata. Ainda, em T. pseudomaculata, notouse a existência de fragmentos nucleolares próximos aos cromossomos. Este comportamento está relacionado ao fenômeno da persistência nucleolar, no qual o 
nucléolo não desaparece totalmente nos triatomíneos, mas se preserva como corpúsculos pré-nucleolares (TARTAROTTI; AZEREDO-OLIVEIRA, 1999; MORIELLE; AZEREDO-OLIVEIRA, 2004). Nas espermátides, foi constatada a presença de um pequeno corpúsculo impregnado por íons prata.

Sabe-se que os íons prata ligam-se a um grupo especial de proteínas acídicas existentes no nucléolo (C23 e B23). É conhecido que o nucléolo possui um ciclo de desagregação e reorganização, isto é, rompimento durante a prófase tardia e reorganização no início da telófase (ASHRAF; GODWARD, 1988). No entanto, vários exemplos, em diferentes espécies animais e vegetais, mostram evidências de que o material fibrilar, principalmente, e algumas vezes, o granular, podem persistir durante todas as fases do ciclo celular, incluindo a metáfase e a anáfase. Essas evidências suportaram a possibilidade de que o material nucleolar não seja totalmente sintetizado na região cromossômica do organizador nucleolar, mas um material pré-existente seja também necessário e utilizado (ASHRAF; GODWARD, 1988).

Os resultados observados nesse trabalho, somente pela impregnação por prata, estão de acordo com a persistência nucleolar no ciclo celular meiótico porque os corpúsculos pré-nucleolares podem se observados em vários estágios durante a divisão celular. Esses corpúsculos pré-nucleolares permanecem na célula, após a prófase, durante o ciclo, até a telófase. Os mesmos aspectos foram verificados na espermatogênese de outros triatomíneos do gênero Triatoma (TAVARES; AZEREDOOLIVEIRA, 1997b) e Rhodnius (MORRIELE; AZEREDO-OLIVEIRA, 2004; 2007).

Por outro lado, outros resultados obtidos sobre a espermatogênese dos triatomíneos, com base em técnicas de bandamento fluorescente e hibridação in situ fluorescente (FISH), não detectaram a presença desses corpúsculos durante as divisões celulares meióticas, nem nas espermátides. Tais corpúsculos foram, então, corados tanto pela orceína como pelos íons prata, mas não foram detectados por fluorocromos e por FISH (SEVERI-AGUIAR; AZEREDO-OLIVEIRA, 2005a, b; 2006).

Portanto, a natureza citoquímica desses corpúsculos, detectados também na espermatogênese de T. maculata e T. pseudomaculata, durante as fases da meiose até as fases iniciais das espermátides, sugere que os mesmos representem uma fonte de RNA associado à proteínas específicas, constituindo complexos de ribonucleoproteínas (RNPs). Essa fonte de RNPs é muito importante nas fases iniciais da espermatogênese quando ocorre uma série sucessiva de eventos, nos quais as células haplóides sofrem transformações nucleares e condensação da cromatina, desenvolvendo estruturas 
especiais como o acrossomo e o flagelo (PARVINEN et al., 1986). Durante esse padrão de diferenciação, a célula, momentaneamente, diminui a síntese de proteína (MIRRE; KNIBIEHLER, 1985). Os achados em triatomíneos podem indicar que suprimentos de RNPs são necessários à síntese protéica da espermátide. Os pequenos pontos vistos nas espermátides desses insetos, tanto por meio da coloração pela orceína como pela impregnação pela prata, evidenciam a presença desses corpúsculos de RNPs, já que os mecanismos dessas técnicas, por acidofilia e por ligação dos íons prata, indicam que apenas as proteínas são marcadas.

Com base nas análises citogenéticas realizadas nas duas espécies, T. maculata e T. pseudomaculata, podemos destacar várias semelhanças na estrutura nuclear e cromossômica: mesmo número cromossomômico $(2 n=22)$; associação entre nucléolo e regiões heterocromáticas; cromossomo $\mathrm{Y}$ heterocromático, rico em bases $\mathrm{AT}$; cromossomos autossomos com a mesma composição de bases; persistência nucleolar ao longo do ciclo celular meiótico.

As poucas diferenças citogenéticas encontradas, tais como: tamanho cromossômico e marcação pelos íons prata indicam que $T$. maculata e $T$. pseudomaculata compartilham características nucleares próximas.

\subsection{Técnica molecular}

As análises moleculares são importantes ferramentas em genética, como na distinção de espécies, na avaliação do posicionamento sistemático dessas, assim como os seus relacionamentos evolutivos (ABAD-FRANCH; MONTEIRO, 2005). Uma das maiores contribuições das técnicas moleculares é em relação à classificação dos triatomíneos, que, atualmente, está baseada, principalmente, nos diversos caracteres morfológicos, tais como, coloração, tamanho do inseto, aspectos das antenas, do rostro, pronoto, mesonoto, escutelo, das pernas, asas, genitálias externas, dos ovos e de outras características (GALVÃO et al., 2003; LENT; WYGODZINSKY, 1979). Além das características morfológicas, a citogenética também proporciona, frequentemente, alguns parâmetros que auxiliam na distinção entre as espécies (LENT; WYGODZINSKY, 1979; CARCAVALLO et al., 1997, 1999). Mesmo com todas estas análises, algumas espécies de Triatominae ainda são muito semelhantes em sua coloração, características morfológicas e cromáticas, dificultando sua identificação. 
Nos últimos anos, o DNA ribossomal (DNAr) vem sendo amplamente utilizado em estudos filogenéticos de vários níveis taxonômicos, desde filo a populações, tanto para organismos próximos quanto para organismos distantes (BARGUES et al., 2000; JARAMILLO et al., 2001). O DNA ribossômico é responsável pela síntese dos RNAs ribossomais e está organizado em unidades repetitivas em tandem nas regiões organizadoras nucleolares (RONs), apresentando nos insetos de 100 a 1000 cópias por genoma (TARTAROTTI, 1998). Cada unidade consiste de regiões conservadas transcritas, nas quais estão os genes para as subunidades $18 \mathrm{~S}, 5,8 \mathrm{~S}$ e $28 \mathrm{~S}$ do ribossomo, dois espaçadores internos ITS-1 e ITS-2 e um espaçador externo (ETS) ou espaço intergênico (IGS) (HILLIS; DIXON, 1991; PASKEWITZ et al., 1993). Por ser uma região conservada e estar presente em todos os organismos, o DNAr mostrou-se um valioso auxílio para as pesquisas já cada unidade de rDNA evolui de forma sincronizada, dessa maneira, a variação dentro de uma mesma espécie é muito pequena, porém existe variação suficiente que permite a diferenciação entre as espécies. A evolução sincronizada do DNAr dentro das espécies resultou no uso dos espaçadores internos não só para reconstruções filogenéticas, mas também como marcador molecular para a diferenciação das espécies, incluindo espécies crípticas e próximas (BARGUES et al., 2002; MARCILLA et al., 2002; COLEMAN, 2003; NAEGELE et al., 2006).

No presente trabalho, pode-se verificar, por meio de técnicas citogenéticas convencionais e moleculares as diversas semelhanças compartilhadas entre T. maculata e T. pseudomaculata, não sendo possível estabelecer nenhum parâmetro seguro que pudesse auxiliar na distinção destas espécies, indicando assim o grau de proximidade entre elas. Deste modo, foi realizado o sequenciamento da região ITS-1, na tentativa de encontrar um marcador eficiente na diferenciação destas espécies e também a relação existente entre elas.

Devido as suas características morfológicas e cromatínicas semelhantes, $T$. pseudomaculata foi, durante vários anos, erroneamente identificada como Triatoma maculata. A espécie só foi corretamente descrita em 1964, a partir de espécimes coletados no Estado do Ceará (CARBAJAL DE LA FUENTE et al., 2008).

A origem destas espécies e a relação existente entre elas ainda é pouco conhecida. De acordo com a hipótese de Schofield (1988), T. maculata e T. pseudomaculata apresentam um ancestral comum, que em determinado momento teve suas ninfas dispersas para uma nova região, por meio da migração dos pássaros, 
iniciando, dessa forma, duas novas populações geograficamente distintas, que, com o tempo, originaram duas novas espécies.

As semelhanças externas compartilhadas entre T. maculata e T. pseudomaculata foram sempre notadas por especialistas. Lent e Wygodzinsky (1979) observaram estas características e perceberam que as duas espécies são dificilmente diferenciadas utilizando apenas características externas como o padrão de cor. Ainda, segundo estes autores, a melhor característica para a distinção entre estas espécies é a genitália masculina. Estas similaridades foram responsáveis para o estabelecimento do complexo T. maculata que compreende exclusivamente estas duas espécies (CARCAVALLO et al., 2000). Apesar dessas inúmeras semelhanças morfológicas, alguns autores não aceitam o atual agrupamento destas espécies dentro do complexo T. maculata e apontam a existência de uma terceira espécie, Triatoma wygodzinskyi, que exibe similaridades morfológicas próximas à T. pseudomaculata (CARCAVALLO et al., 2000). De acordo com Hypsa et al. (2002) e Santos et al. (2007), T. maculata e T. pseudomaculata deveriam pertencer à linhas evolutivas distintas, em que, $T$. pseudomaculata e T. wygodzinskyi seriam consideradas espécies relacionadas.

Santos et al. (2007) a partir de dados enzimáticos, citogenéticos e morfométricos, sugere a formação de um grupo diferente, contendo apenas $T$. wygodzinskyi e T. pseudomaculata, colocando T. maculata em uma linha evolutiva diferente. Além destes autores, Carbajal de La Fuente et al. (2008) também verificaram uma significante similariedade entre T. pseudomaculata e T. wygodzinskyi, a partir de análises fenotípicas das antenas. Apesar das similaridades e da íntima relação evolutiva encontradas entre T. pseudomaculata e T. wygodzinskyi, Carbajal de La Fuente et al. apontaram em um estudo posterior (2009) as notáveis diferenças das características ecológicas entre estas espécies, por exemplo, em ambientes silvestres, T. wygodzinskyi é rupestre enquanto que $T$. pseudomaculata é arbórea.

Com base em estudos moleculares, Hypsa et al. (2002) e Paula et al. (2005), mostraram uma grande diferença genética entre $T$. maculata e $T$. pseudomaculata, e uma relação próxima entre T. pseudomaculata e T. wygodzinskyi. Apesar do trabalho desenvolvido por Hypsa et al. (2002) não ter solucionado a relação entre estas duas espécies, suas análises filogenéticas teriam indicado T. pseudomaculata mais próximo de T. wygodzinskyi, deste modo, se faz necessário mais análises a fim de solucionar completamente a relação entre estas espécies. 
Por meio das análises moleculares realizadas no neste estudo trabalho foi possível conhecer as sequências da região ITS-1 do DNA ribossomal e verificar as posições em que ocorreram as divergências de nucleotídeos, indicando deste modo, que as espécies estudadas estão muito próximas entre si, sendo de 98,5\% de homologia, deste modo, devem continuar agrupadas no complexo T. maculata, discordando de alguns autores que propõem uma reorganização dessas espécies (SANTOS et al., 2007; CARBAJAL DE LA FUENTE et al., 2008; HYPSA et al., 2002; PAULA et al., 2005).

Semelhante aos resultados obtidos no presente trabalho, Sainz et al. (2004) por meio das análises das sequências dos genes ribossomais do DNA mitocondrial (12S e 16S), também sugerem que $T$. maculata e $T$. pseudomaculata sejam espécies relacionadas intimamente. Nesse trabalho, as análises filogenéticas obtidas, tanto pelo método Neighbor joining quanto pela Máxima parcimônia indicaram o agrupamento destas espécies em um único cluster. Segundo esses autores, este agrupamento foi fortemente apoiado em todas as análises filogenéticas, sendo estas espécies morfologicamente e geneticamente muito semelhantes, diferindo em apenas 0,2-0,8\% nucleotídeos.

Apesar de T. maculata e T. pseudomaculata serem frequentemente domiciliares e peridomiciliares, acredita-se que estas espécies estejam constantemente relacionadas aos pássaros, apoiando a hipótese de que estas duas espécies teriam sido o resultado da evolução de duas populações alopátricas, originada por uma população em comum que teve algumas de suas ninfas dispersas por meio da migração de pássaros (SCHOFIELD, 1988).

Considerando que a hibridização entre triatomíneos permita a formulação de hipóteses a respeito a origem e a diversidade das espécies, Belisário et al. (2007) realizaram o cruzamento entre $T$. maculata e $T$. pseudomaculata. Como resultado, estes autores demonstraram que ambas as espécies não apresentaram diferenças em relação aos padrões reprodutivos e que estas espécies são capazes de cruzarem entre si, gerando híbridos inférteis, indicando mais uma vez a proximidade entre as espécies estudadas.

O sequenciamento também forneceu o tamanho exato dos fragmentos amplificados para a região ITS-1, indicando que T. maculata possui um fragmento menor que T. pseudomaculata. Segundo Marcilla et al. (2001), em geral, as sequências ITS possuem a mesma extensão em diferentes espécies do mesmo gênero. $\mathrm{O}$ mesmo não foi observado neste trabalho. Apesar da proximidade entre as espécies, foi verificada uma diferença em torno de 50 pares de bases para a espécie $T$. 
pseudomaculata. Esta diferença na extensão em diferentes espécies de triatomíneos também foi observada por Tartarotti (1998), principalmente no gênero Triatoma. Nesse estudo, a análise da região intergênica ITS-1 do DNA ribossômico permitiu a observação da variabilidade genética existentes entre Rhodnius domesticus, $R$. neivai, $R$. robustus, Triatoma brasiliensis, T. infestans, T. vitticeps, Panstrongylus herreri e $P$. megistus. As espécies de Rhodnius apresentaram tamanho da região ITS-1 com, em média, $300 \mathrm{pb}$, sendo que $R$. domesticus e $R$. neivai apresentaram padrões semelhantes. A espécie $R$. robustus apresentou tamanho um pouco menor, em torno de $250 \mathrm{pb}$. Nesse trabalho, a diferenciação entre gêneros foi evidente, pois o tamanho da região ITS-1 dos gêneros Triatoma e Panstrongylus foi de 600 a 1000 pb, sendo que, T. brasiliensis apresentou um fragmento de $850 \mathrm{pb}$, enquanto que T. infestans apresentou $750 \mathrm{pb}$. No gênero Panstrongylus, a espécie P. herreri apresentou 600 pb e P. megistus 800 pb.

Os dados da literatura indicam, portanto, que o sequenciamento da região ITS-1 do DNA ribossomal mostra-se eficiente para a distinção das espécies, gerando fragmentos específicos, servindo como um possível marcador molecular.

A grande similaridade ecológica e morfológica, relatadas na literatura, e a relação íntima das características celulares das duas espécies analisadas no presente estudo, T. maculata e T. pseudomaculata, verificadas pelas técnicas citogenéticas e pelo sequenciamento da região ITS-1, suportam a hipótese que essas duas espécies devam ser agrupadas no complexo T. maculata e que tenham tido a mesma origem. 


\section{CONCLUSÕES}

Os resultados obtidos no presente estudo sobre a espermatogênese de $T$. maculata e T. pseudomaculata, por meio de técnicas citogenéticas clássicas e molecular, corroboraram e ampliaram os conhecimentos sobre a citogenética desses insetos hematófagos, vetores da doença de Chagas.

Em relação à contribuição científica desta parte do estudo, pode ser destacado:

a) Mesmo número cromossômico $(2 \mathrm{n}=22)$;

b) Nas duas espécies foi observada uma associação entre nucléolo e regiões heterocromáticas;

c) As regiões heterocromáticas foram semelhantes, tanto na cromatina dos núcleos interfásicos quanto nos cromossomos já condensados, indicando que a localização dessas regiões cromossômicas é bastante homogênea nas duas espécies analisadas. Em relação aos cromossomos sexuais, ambas as espécies apresentaram o cromossomo Y heterocromático;

d) Composição homogênea de bases das regiões heterocromáticas entre as duas espécies;

e) Persistência nucleolar ao longo do ciclo celular meiótico;

f) As técnicas citogenéticas indicaram as semelhanças existentes entre as duas espécies estudadas, o que pode ser comprovado por meio do sequenciamento da região ITS-1 do DNA ribossômico, evidenciando o elevado grau de proximidade entre estas espécies, indicando que devam continuar agrupadas no complexo T. maculata. 


\section{REFERÊNCIAS BIBLIOGRÁFICAS}

ABAD-FRANCH, F.; MONTEIRO, F. A. Molecular research and the control of Chagas' disease vectors. Anais da Academia Brasileira de Ciências, v. 77, n. 3, p. 437-54, 2005.

ASHRAF, M.; GODWAR, M. B. E. The nucleolus in telophase, interphases and profase. Journal of Cell Science, v.41, p. 321-329, 1988.

AZEREDO-OLIVEIRA, M. T. V. Estudo citogenético de túbulos de Malphigi, glândulas salivares e testículos de triatomíneos (Triatominae, Heteroptera). São José do Rio Preto, SP. 1990, 250p. Tese (Doutorado em Ciências Biológicas - Área de concentração em Genética). Instituto de Biociências, Letras e Ciências Exatas/UNESP.

BAFFI, M. A.; CERON, C. R. Molecular analysis of the rDNA ITS-1 Intergenic Spacer in Drosophila mulleri, D. arizonae and their hybrids. Biochemical Genetics, v. 40 (11/12): 411-421, 2002.

BARDELLA, V. B.; AZEREDO-OLIVEIRA, M. T. V.; TARTAROTTI, E. Cytogenetic analysis in the spermatogenesis of Triatoma melanosoma (Reduviidae; Heteroptera). Genetics and Molecular Research, v. 7, n. 2, p. 326-335, 2008.

BARGUES, M. D.; MARCILLA, A.; DUJARDIN, J. P.; MAS-COMA, S. Triatominae vectors of Chagas disease: a molecular perspective based on nuclear ribosomal DNA markers. Transactions of the Royal Society of Tropical Medicine and Hygiene, v. 96, p. 159-164, 2002.

BARGUES, M. D.; MARCILLA, A.; RAMSEY, J. M.; DUJARDIN, J. P.; SHOFIELD, C. J.; MASCOMA, S. Nuclear rDNA-based molecular clock of the evolution of Triatominae (Hemiptera:Reduviidae), Vectors of Chagas disease. Memórias do Instituto Oswaldo Cruz, v. 95: 567-573, 2000.

BARTH, R. Estudos anatômicos e histológicos sobre a subfamília Triatominae (Hemiptera, Reduviidae), V parte: Anatomina do testículo e espermiogênese do Triatoma infestans. Memórias do Instituto Oswaldo Cruz, v. 54, n. 1, p. 135-184, 1956.

BELISÁRIO, C. J.; PESSOA, G. C. A.; DIOTAIUTI, L. Biological aspects of crosses between Triatoma maculata (Erichson, 1848) and Triatoma pseudomaculata (Corrêa \& Espínola, 1964) (Hemiptera: Reduviidae Memórias do Instituto Oswaldo Cruz, v. 102, N. 4, P. 517-521, 2007. 
CARBAJAL DE LA FUENTE, A. L.; NOIREAU, F.; CATALÁ, S. S. Interferences about antennal phenotype: the "Triatoma maculata complex" (Hemiptera: Triatominae) is valid? Acta Tropica, v. 106, p. 16-21, 2008.

CARCAVAllo, R. U.; JURBERG, J.; LENT, H.; NOIREAU, F.; GALVÃO, C. Phylogeny of Triatominae (Hemiptera: Reduviidae). Propols for taxonomic arrangements. Entomologia y Vectores, v.7, p. 1-99, 2000.

CARCAVALLO, R. U.; GALÍNDEZ- GÍRON，I.; JURBERG，J.; GALVÃO，C.; LENT, H.; MARTINEZ, A.; OTERO AROCHA, M. A.; ROCHA, D. S. Pictorial keys for tribes, genera and species of the subfamily Triatominae . In: CARCAVALLO, R.U.; GALÍNDEZ- GÍRON, I.; JURBERG, J. ; LENT, H. (Ed.) Atlas of Chagas disease vectors in the Americas. Rio de Janeiro: Fiocruz, 1997. v. 1, p. 107- 244.

CARCAVAllo, R. U.; JURBERG, J.; LENT, H. Phylogeny of the triatominae. In Atlas of Chagas' disease vectors in the Americas. Chapter 21, P. 569-925, 1999.

CASSEB-HASSAN, P. M.; AZEREDO-OLIVEIRA, M. T. V. Estrutura nucleolar e impregnação por íons prata. HB Científica, v. 6, n.3, p. 173-178, 1999.

COLEMAN, A. W. ITS2 is a double-edged tool for eukaryote evolutionary comparisons. Trends in Genetics v. 19, n. 7, p. 370-75, 2003.

COSTA, J.; FELIX, M. Triatoma juazeirensis sp. nov. from the state of Bahia, Northeastern Brazil (Hemiptera: Reduviidae: Triatominae). Memórias do Instituto Oswaldo Cruz, v.102, n. 87-90, 2007.

COSTA, J.; ARGOLO, A.; FELIX, M. Redescription of Triatoma melanica Neiva \& Lent, 1941, new status (Hemiptera: Reduviidae: Triatominae). Zootaxa, v. 1385, p. 47$58,2006$.

DE VAIO, E. S.; CRUCCI, B.; CASTAGNINO, A. M.; FRANÇA, M. E.; MARTINEZ, M. E. Meiotic diferences between three triatomine species (Heteroptera, Reduviidae). Genetica, v. 67, p. 185-191, 1985.

DIAS, J. P. C.; MACHADO, E. M. M.; FERNANDES, A. L.; VINHAES, M. C. Esboço geral e perspectiva da doença de Chagas no Nordeste do Brasil. Cadernos de Saúde Pública, v. 16, p. 13-34, 2000. 
DUJARDIN, J. P.; SCHOFIELD, C. J.; ROMANHA, A. J.; DIOTAJUTI, L. Genetic variability of Triatoma, Tropical Medicine and Hygiene, v. 92, p. 137-143, 1998.

ESPÍNOLA, H.; RODRIGUEZ, F.; BERMUDEZ, M.; TONN, R. J. Informaciones sobre la biologia y el ciclo de vida de Triatoma maculata (Erichson, 1848) (Hemiptera, Reduviidae, Triatominae), en condiciones de laboratorio. Boletin de la Dirección de Malariología y Saneamiento Ambiental, v. 21, p. 140-142, 1981.

FORERO, D., WEIRAUCH, C.; BAENA, M. Synonymy of the reduviid (Hemiptera: Heteroptera) genus Torrealbaia (Triatominae) with Amphibolus (Harpactorinae), with notes on Amphibolus venator (Klug, 1830) Zootaxa, v. 670, p. 1-12, 2004.

FREITAS, S. P. C; LOROSA, E. S; RODRIGUES, D. C. S; FREITAS, A. L. C; GONÇALVES, T. C. M. Fontes alimentares de Triatoma pseudomaculata no Estado do Ceará, Brasil. Revista de Saúde Pública, v. 39, n. 1, p. 27-32, 2005.

GAlletTI-JÚNIOR, P. M.; SILVA, E. B.; CERMINARO, R. T. A Multiple NOR system in the fish Serrasalmus spilopleura (Serrasalminae, Characidae). Revista Brasileira de Genética, v.8, n.3, p.479-484, 1985.

GALVÃO, C.; ÂNGULO, V. M. Belminus corredori, a new species of Bolboderini (Hemiptera: Reduviidae: Triatominae) from Santander, Colombia. Zootaxa, v. 1241, p. 61-68, 2006.

GALVÃO, C.; CARCAVALLO, R.; ROCHA, D. S.; JURBERG, J. A checklist of the current valid species of the subfamily Triatominae Jeannet, 1919 (Hemiptera, Reduviidae) and their geographical distribuition, with nomenclatural and taxonomic notes. Zootaxa, v. 202, p. 1-36, 2003.

GROZEVA, S.; NOKKALA, S.; SIMOV, N. First evidence of sex chromosome préreduction in male meiosis in the Miridae Bugs (Heteroptera). Folia Biologica, v. 54, p. 9-12, 2006.

GUERRA, M. Introdução à Citogenética Geral. Rio de Janeiro: Guanabara, 1988. $142 p$.

HILLIS, D. M.; DIXON, M. T. Ribossomal DNA: Molecular evolution and phylogenetic inference. The Quarterly Review of Biology, v. 66, p. 411-453, 1991. 
HOWELL, W; BLACK, D. A. Controlled silver staining of nucleolus organizer regions with protective colloidal developer: al-estep method. Experientia, v. 36, p. 1014 $1015,1980$.

HOY, M. A. Insect molecular systematics and evolution. In: Insect molecular genetics: An introduction to principles and applications (Hoy, M. A. eds.). Academic press, p. 360-363, 1994.

HUGHES-SCHRADER, S.; SCHRADER, F. The kinetochore of the Hemiptera. Chromosoma, v. 12, p. 327-350, 1961.

HYPSA, V.; TIETZ, D. F.; ZRZAVÝ, J.; REGO, R. O. M.; GALVÃO, C.; JURBERG, J. Phylogeny and biogeography of Triatominae (Hemiptera: Reduviidae): molecular evidence of a New World origin of the Asiatic clade. Molecular Phylogenetics and Evolution, v.23, p. 447-57, 2002.

JARAMILLO, C.; MONTAÑA, M. F. CASTRO, L. R;. VALLEJO, G. A.; GUHL, F. Differentiation and genetic analysis of Rhodnius prolixus and Rhodnius colombiensis by rDNA and RAPD amplification. Memórias do Instituto Oswaldo Cruz, v. 96, n. 8, p. 1043-1048, 2001.

LENT, H.; WYGODZINSKY, P. Revision of the Triatominae (Hemiptera, Reduviidae), and their signignificance as vectors of Chagas' Disease. Bulletin of the American Museum of Natural History, v. 163, n. 3, 1979.

LONG, E. O.; DAVID, I. B. Repeated genes in eukaryotes. Annual Review of Biochemistry, v. 49, p. 727-764, 1980.

LYMAN, D. F.; MONTEIRO, F. A.; ESCARLATE, A. A.; CORDON-ROSALES, C.; WESSON, D. W.; DUJARDIN, J. P.; BEARD, C. B. Mitochondrial DNA sequence variation among Triatomine vectors of Chagas' disease. The American Journal of Tropical Medicine and Hygiene, v. 60, p. 377-386, 1999.

MANNA, G. K. Multiple sex chromosome mechanis in a reduviid bug, Conorhinus rubrofasciata, De Geer. Proceedings of the Zoological Society of Bengal, v. 3, p. 155$161,1950$.

MANOMANI, A.; TOWSON, H.; ADENIRAN, T. rDNA - ITS-2 polimerase chain reaction assay for the sibling species of Anopheles fluviatilis. Acta Tropica, v. 78, p. 39, 2001. 
MARCILLA, A.; BARGUES, M. D.; RAMSEY, J. M.; MAGALLON-GASTELUM E.; SALAZAR-SCHETTINO, P. M.; ABAD-FRANCH, F.; DUJARDIN, J. P.; SCHOFIELD, C. J.; MAS-COMA, S. The ITS-2 of the nuclear rDNA as a molecular marker for populations, species and phylogenetic relationships in triatominae (Hemiptera:Reduviidae), vectors of Chagas Disease. Molecular Phylogenetics and Evolution, v. 18, p. 136-142, 2001.

MARCILLA, A.; BARGUES, M. D.; ABAD-FRANCH, F.; PANZERA, F.; CARCAVALLO, R. U.; NOIREAU, F.; GALVÃO, C.; JURBERG, J.; MILES, M. A.; DUJADIN, J. P.; MAS- COMA, S. Nuclear rDNA ITS-2 sequence reveal polyphyly of Panstrongylus species (Hemiptera: Reduviidade: Triatominae), vectors of Trypanosoma cruzi. Infection, Genetics and Evolution., v. 1, p. 225- 235, 2002.

MCCLINTOCK, B. The relationship of a particular chromosomal element to the development of the nuclei in Zea mays. Zeitschrift für Zellforschung und Mikroskopische Anatomie, v. 21, p. 294-328, 1934.

MELlO, M. L. S. Heterocromatina. Ciência e Cultura, v. 30, n. 3, p. 290-303, 1978.

MELLO, M. L. S.; VIDAL, B. C. Práticas de Biologia Celular. Campinas: FUNCAMP. Editora Edgard Blcher Ltda, 1980.

MIRRE, C. KNIBIEHLER, B. Ultrastructural and functional variations in the spermatid nucleolus during spermiogenesis in the mouse. Cell Differenciation, $v$. 16, p. 51-61, 1985.

MONTEIRO, F. A.; PÉREZ, R.; PANZERA, F.; DUJARDIN, J-P.; GALVÃO, C.; ROCHA, D.; NOIREAU, F.; SHOFIELD, C.; BEARD, C. B. Mitochondrial DNA variation of Triatoma infestans populations and its implication on the specific status of T. melanosoma. Memórias do Instituto Oswaldo Cruz, v. 94, suppl. I, p. 229-238, 1999.

MORIELLE, A. Análise do ciclo nucleolar e da estrutura cromossômica em Triatomíneos (Heteroptera, Triatominae). São José do Rio Preto-SP, 127 f., 2004. Tese (Doutorado em Genética), Instituto de Biociências, Letras e Ciências Exatas/UNESP.

MORIELLE, A.; AZEREDO-OLIVEIRA, M. T. V. Description of the nucleolar activity and Karyotype in germinative cell lines of Rhodnius domesticus (Triatominae, Heteroptera). Caryologia, v. 57, n. 1, p. 31-37, 2004. 
MORIELLE, A; AZEREDO-OLIVEIRA, A. T. V. Differencial characterization of holocentric chrmosomes in triatomines (Heteroptera, Triatominae). Genetics and Molecular Research, v. 6, n. 3, p. 713-720, 2007.

MORIELLE-SOUZA, A.; AZEREDO-OLIVEIRA, M. T. V. Study of the nucleolar cycle and ribosomal RNA distribution during meiosis in triatomines (Triatominae, Heteroptera). Micron, v. 39, p. 1020-1026, 2008.

NAEGELE, M. P.; DA COSTA, P. I.; ROSA, J. A. Polymorphism of the ITS-2 region of the ribosomal DNA of the Triatominae Rhodnius domesticus, $R$. pictipes, $R$. prolixus and $R$. stali. Medical and Veterinary Entomology, v. 20, n. 4, p. 353-357, 2006.

ONYABE, D. Y.; CONN, J. E. Intragenomic heterogeneity of a ribosomal DNA spacer (ITS2) varies regionally in the neotropical malaria vector Anopheles nuneztovari (Dipetera: Culicidae). Insect Molecular Biology, v. 8, p. 435-442, 1999.

OSCH, R. L.; BUSCH, H. Further evidence that phosphoprotein C23 (110kd/p15, I) is the nucleolar silver staining protein. Experimental Cell Research, v. 152, p. 260-265, 1984.

PANZERA, F.; PEREZ, R.; PANZERA, Y.; ALVAREZ, F.; SCVORTZOFF, E.; SALVATELA, R. Karyotype evolution in holocentric chromosomes of three related species of triatomines (Heteroptera-Reduviidae). Chromosome Research, v. 3, p. 143$150,1995$.

PARVINEN, M., VIHKO, K. K., TOPPARI, J. Cell Interactions during the seminiferous epithelial cycle. In: Cytology: A survery of cell biology. 3.ed. New York: Academic Press, 1986, p.115-151.

PASKEWITZ, S.M.; WESSON, D.M.; COLLINS, F.H. The internal transcribed spacers of ribossomal DNA in five members of Anopheles gambiae species complex. Insect Molecular Biology, v. 2, n. 4, p. 247- 257, 1993.

PAULA, A. S.; DIOTAIUTI, L.; SCHOFIELD, C. J. Testing the sister-group relationship of the Rhodiini and Triatomini (Insecta: Hemiptera: Reduviidae: Triatominae). Molecular Phylogenetics and Evolution, v. 35, p. 712-718, 2005.

PAYNE, F. Some new tipes of chromosomes distribuition and their relation of sex. Biological Bulletin, v. 16, p. 119-166, 1909. 
PÉREZ, R.; PANZERA, Y.; SCAFIEZZO, S.; MAZZELLA, M. C.; PANZERA, F.; DUJARDIN, J. P.; SCVORTZOFF, E. Cytogenetics as a tool for Triatominae species distinction (Hemiptera-Reduviidade). Memórias do Instituto Oswaldo Cruz, v. 87, n. 3, p. 353-361, 1992.

POLANCO, C.; GONZÁLEZ, A. I.; FUENTE, A.; DOVER, G. A. Multigene Family of ribosomal DNA in Drosophila melanogaster reveals contrasting patterns of homogenization for IGS and ITS Spacer Regions: A Possible mechanism to Resolve this Paradox. Genetics, v. 149, p. 243-256, 1998.

ROJAS, M. E.; VÁRQUEZ, P.; VILLARREAL, M. F.; VELANDIA, C.; VERGARA, L.; MORÁN-BORGES, Y. H.; ONTIVEROS, J.; CALDERÓN, M. Y.; CHIURILLOSIERVO, M.; RODRÍGUEZ-BONFANTE, C. C.; ALDANA, E.; CONCDEPCIÓN, J. L.; BONFANTE-CABARCAS, R. A. Estudio seroepidemiológico y entomológico sobre la enfermedad de Chagas en un área infestada por Triatoma maculata (Erichson 1848) en el centro-occidente de Venezuela. Revista do Instituto de Medicina Tropical de São Paulo, v. 47, n. 3, p. 131-137, 2005.

SANDOVAL, C. M.; PABÓN, E.; JURBERG, J.; GALVÃO, C. Belminus ferroae n. sp. from the Colombia north-east, with a key to the species of the genus (Hemiptera: Reduviidae: Triatominae). Zootaxa, v. 1443, p. 55-64, 2007.

SAINZ, A. C.; MAURO, L. V.; MORIYAMA, E. N.; GARCÍA, B. A. Phylogeny of triatomine vectors of Trypanosoma cruzi suggested by mitochondrial DNA sequences. Genetica, v. 121, p. 229-240, 2004.

SANTOS, S. M; LOPES, C. M; DUJARDIN, J. P; PANZERA, F; PÉREZ, R; CARBAJAL DE LA FUENTE, A. L; PACHECO, R. S; NOIREAU, F. Evolucionary relationships based on genetic and phenetic characters between Triatoma maculata, Triatoma pseudomaculata and morphologically related species (Reduviidae: Triatominae). Infection, Genetics and Evolution, v. 7, p. 469-475, 2007.

SCHERR, U.; XIA, B.; MERKERT, H.; WEISENBERG, D. Looking at Christmas trees in the nucleolus. Chromosoma, v. 105, n.7-8, p.470-480, 1997.

SCHOFIELD, C. J.; DUJARDIN, J. P. Theories on the evolution of Rhodnius. Actualidades Biologicas, v. 21, p. 183-197, 1999.

SCHOFIELD, C. J. Biosystematics of Triatominae. Biosystematic of Haematophagous Insects, v. 37, p. 287-312, 1988. 
SCHOFIELD, Christopher J. Biossistemática e evolução de triatomíneos. Cadernos de Saúde Pública, v.16, 2000.

SCHRADER, F. Notes on the mitotic behaviour of long chromosomes. Cytologia, v. 6, p. 422-430, 1935.

SCHRADER, F. The role of the Kinetochore in the chromosomal evolution of the Heteroptera and Homoptera. Evolution, v. 1, n. 3, p. 134-142, 1947.

SCHREIBER, G.; PELLEGRINO, J. Análise citológica e cariométrica de ação da colchicina sobre a espermatogênese dos hemípteros. Memórias do Instituto Oswaldo Cruz, v. 45, p. 513-542, 1951.

SCHREIBER, G.; PELLEGRINO, J. Cytogenetical studies on brazilian Hemiptera. Hereditas, v. 656, VIIIth International Congress of Genetics - Stockholm, 1948.

SEVERI-AGUIAR, G. D. C.; AZEREDO-OLIVEIRA, M. T. V. Cytogenetic study on three species of the genus Triatoma (Heteroptera: Reduvidae) with emphasis on nucleolar organizer regions. Caryologia, v. 58, p. 293-299, 2005a.

SEVERI-AGUIAR, G. D. C.; AZEREDO-OLIVEIRA, M. T. V. Localization of rDNA sites in holocentric chromosomes of three species of Triatomines (Heteroptera, Triatominae). Genetics and Molecular Research, v. 4, p. 704-709, 2005 b.

SEVERI-AGUIAR, G. D. C.; LOURENÇO, L. B.; BICUDO, H. E. M. C. AZEREDOOLIVEIRA, M. T. V. Meiosis aspects and nucleolar activity in Triatoma vitticeps (Triatominae, Heteroptera). Genetica, v. 126, p. 141-151, 2006.

SEVERI-AGUIAR, G. D. C. Estudo citogenético em espécies do gênero Triatoma (Heteroptera, Reduviidae) com ênfase à heterocromatina e as regiões organizadoras nucleolares. São José do Rio Preto, SP. 2001, 191f. Tese (Doutorado em Genética), Instituto de Biociências, Letras e Ciências Exatas/UNESP.

SOARES, R. P. P.; BARBOSA, S. E.; DUJARDIN, J. P.; SCHOFIELD, C. J.; SIQUEIRA, A. M.; DIOTAIUTI, L. Characterization of Rhodnius neglectus from two regions of Brazil using isoenzymes, genitalia morphology and morphometry. Memórias do Instituto Oswaldo Cruz, v. 94, n. 2, p. 161-166, 1999. 
SOLARI, A. J. Autosomal synaptonemal complexes and sEx chromosomes without axes in Triatoma infestans (Heteroptera, Reduviidae). Chromosoma, v. 72, p. 225-240, 1979.

STOTHARD, J. R.; YAMAMOTO, Y.; CHERCHI, A. L.; VALENTE, S. A. S., SCHOFIELD, C. J.; MILES, M. A. A preliminary survey of mitochondrial sequence variation in Triatominae (Hemiptera: Reduviidae) using polymerase chain reactionbased single strand conformational polymorphism (SSCP) analysis and direct sequencing. Bulletin of Entomological Research, v. 88, p. 553-560, 1998.

TARTAROTTI, E. Estudo Citogenético em Triatomíneos do gênero Panstrongylus (Triatominae, Heteroptera). (Master thesis). IBILCE - UNESP: Universidade Estadual Paulista Júlio de Mesquita Filho, 1998, 189p.

TARTAROTti, E., AZEREDO-OliveIRA, M. T. V., CERON, C. R. Phylogenetic approach to the study of triatomines (Triatominae, Heteroptera). Brazilian Journal of Biology, v. 66, n.2b, p. 29-41, 2006.

TARTAROTTI, E.; AZEREDO-OLIVEIRA, M. T. V. Pattern of nucleolar activity during spermatogenesis of two triatomines, Panstrongylus megistus and Panstrongylus herreri. Cariologia, v. 52, n.3-4, p. 177-184, 1999.

TARTAROTTI, E.; CERON, C. R. Ribosomal DNA ITS-1 Intergenic Spacer Polymorphism in Triatomines (Triatominae, Heteroptera). Biochemical Genetics, v. 43, n. $7 / 8$, p. 365-373, 2005.

TAVARES, M. G. Estudo citogenético em espécies do gênero Triatoma, com ênfase a estrutura dos cromossomos e região organizadora nucleolar. Dissertação de mestrado. São José do Rio Preto: Instituto de Biociências, Letras e Ciências Exatas, UNESP, 1996, 141p.

TAVARES, M. G.; AZEREDO-OLIVEIRA.; M. T. V. Aspectos bilogógicos e médicosanitários dos Triatomíneos. HB Científica, v. 3, n. 2, p. 137-144, 1996.

TAVARES, M. G.; AZEREDO-OLIVEIRA, M. T. V. Cytogenetics study on holocentric chromosomes of five species of triatomines (Heteroptera: Reduviidae). Cytobios, v. 89, p. 51-61, 1997a.

TAVARES, M. G.; AZEREDO-OLIVEIRA, M. T. V. Pattern of nucleolar activity during spermiogenesis in triatomines (Heteroptera, Reduviidae) as analysed by silver stainig. Cytobios, v. 89, p. 93-103, 1997 b. 
TONN, R. J.; OTERO, M. A.; MORA, E.; ESPINOLA, H.; CARCAVALlO, R. U. Aspectos biológicos, ecológicos y distribución geográfica de Triatoma maculata (Erichson, 1848) (Hemiptera, Reduviidae), en Venezuela. Boletin de la Dirección de Malariología y Saneamiento Ambiental, v. 18, p. 16-24, 1978.

TOVAR, F. J.; SILVA, L. A. F.; RODARTE, R. S. Characterization of ribosomal DNA (rDNA) in Drosophila arizonae. Genetics and Molecular Biology, v. 23, p. 331-333, 2000.

UESHIMA, N. Cytotaxonomy of the Triatominae (Heteroptera-Reduviidae). Chromosoma, v. 18, p. 97-122, 1966.

VIDAL, B. C.; MELLO, M. L. S. Biologia Celular. Rio de Janeiro: Atheneu. 1987p.

WHITE, E. E.; DUBETZ, C. P.; CRUICKSHANK, M. G.; MORRISON, D. J. DNA diagnostic for Armillaria species in British Columbia: within and between species variation in the IGS-1 and IGS-2 regions. Mycologia, v. 90, n.1, p. 125-131, 1998.

WHITE, M. J. D. Animal cytology and evolution. Cambridge Univertsity Press. London, 3 ed., 1973.

WOLF, K. M. The structure of condensed chromosomes in mitosis and meiosis of insects. International Journal of Insect Morphology and Embryology, v. 25, n.1/2, p.37-62, 1996 


\section{ANEXOS}
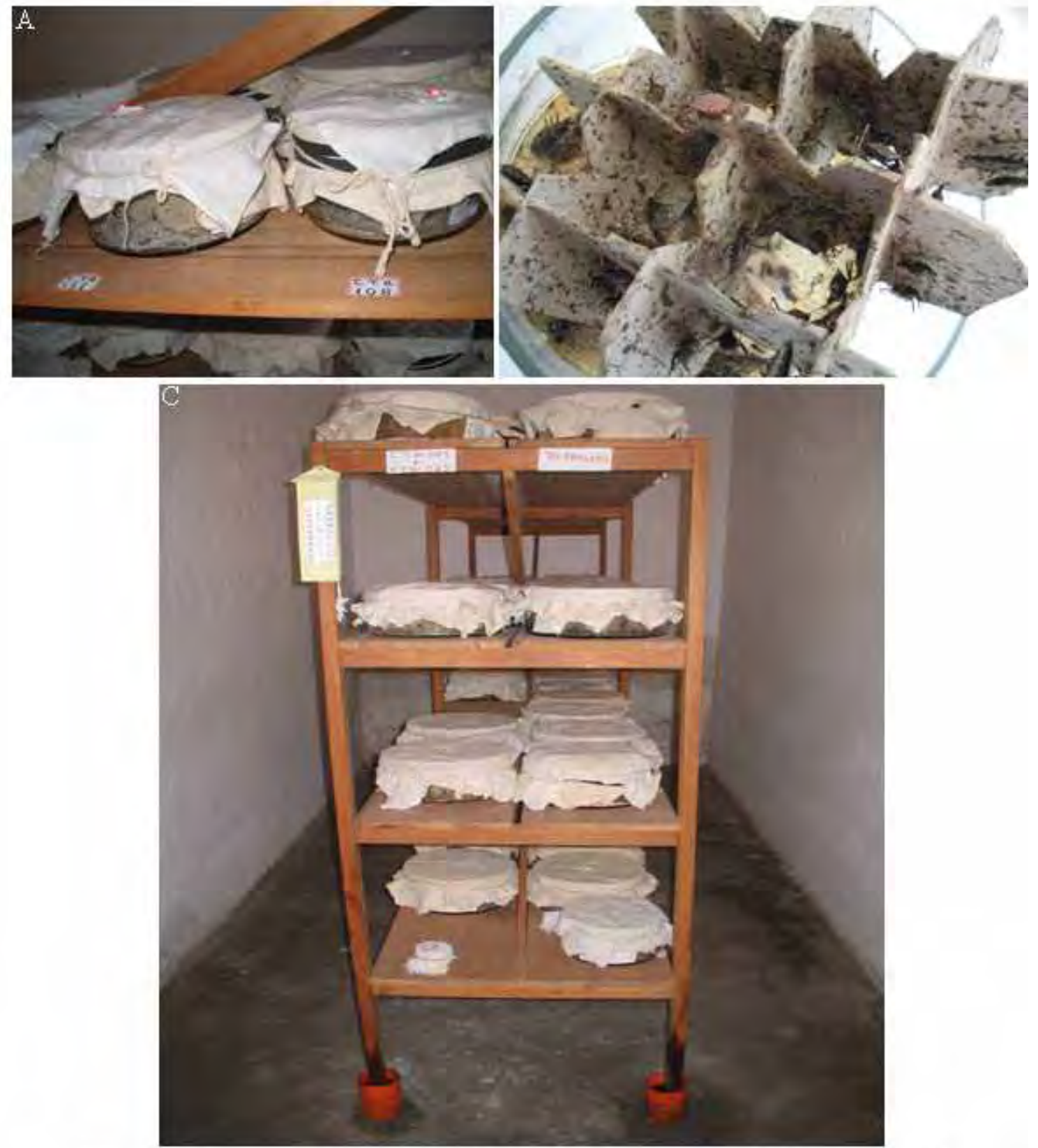

Anexo 1: Manutenção dos insetos. (A) Imagem dos cristalizadores. (B) Repartições internas de papelão. (C) Estantes de madeira. Observar os pés ficam imersos em vasilhas contendo óleo queimado. 

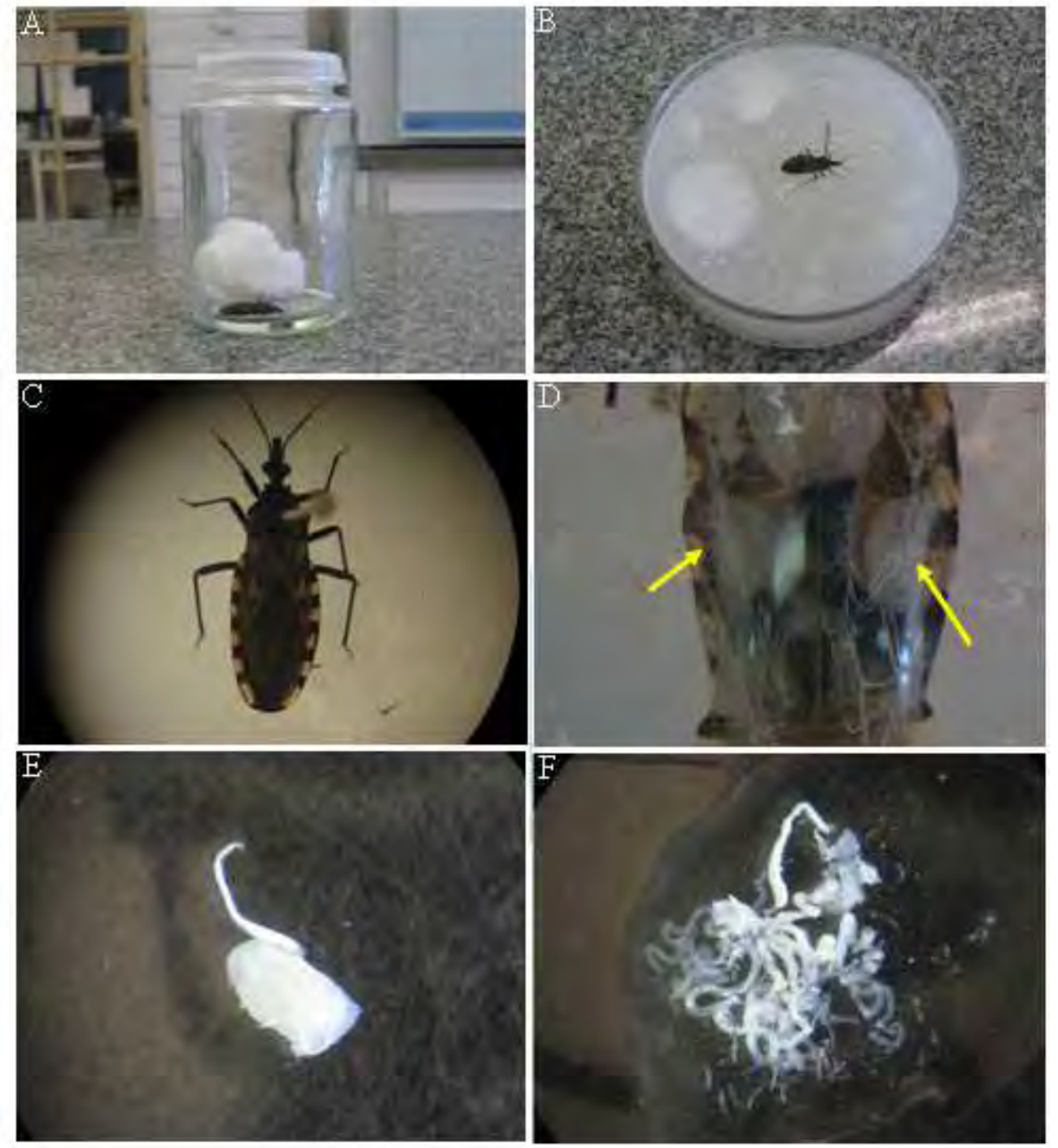

Anexo 2: Dissecação dos insetos. (A) Eterização. (B) Fixação. (C) Inseto sob o microscópio estereoscópico. (D) Visualização dos testículos. (E) Visualização dos testículos. (F) Individualização dos túbulos seminiferos. 